\title{
Assessment of Groundwater/Surface-Water Interaction and Simulation of Potential Streamflow Depletion Induced by Groundwater Withdrawal, Uinta River near Roosevelt, Utah
}

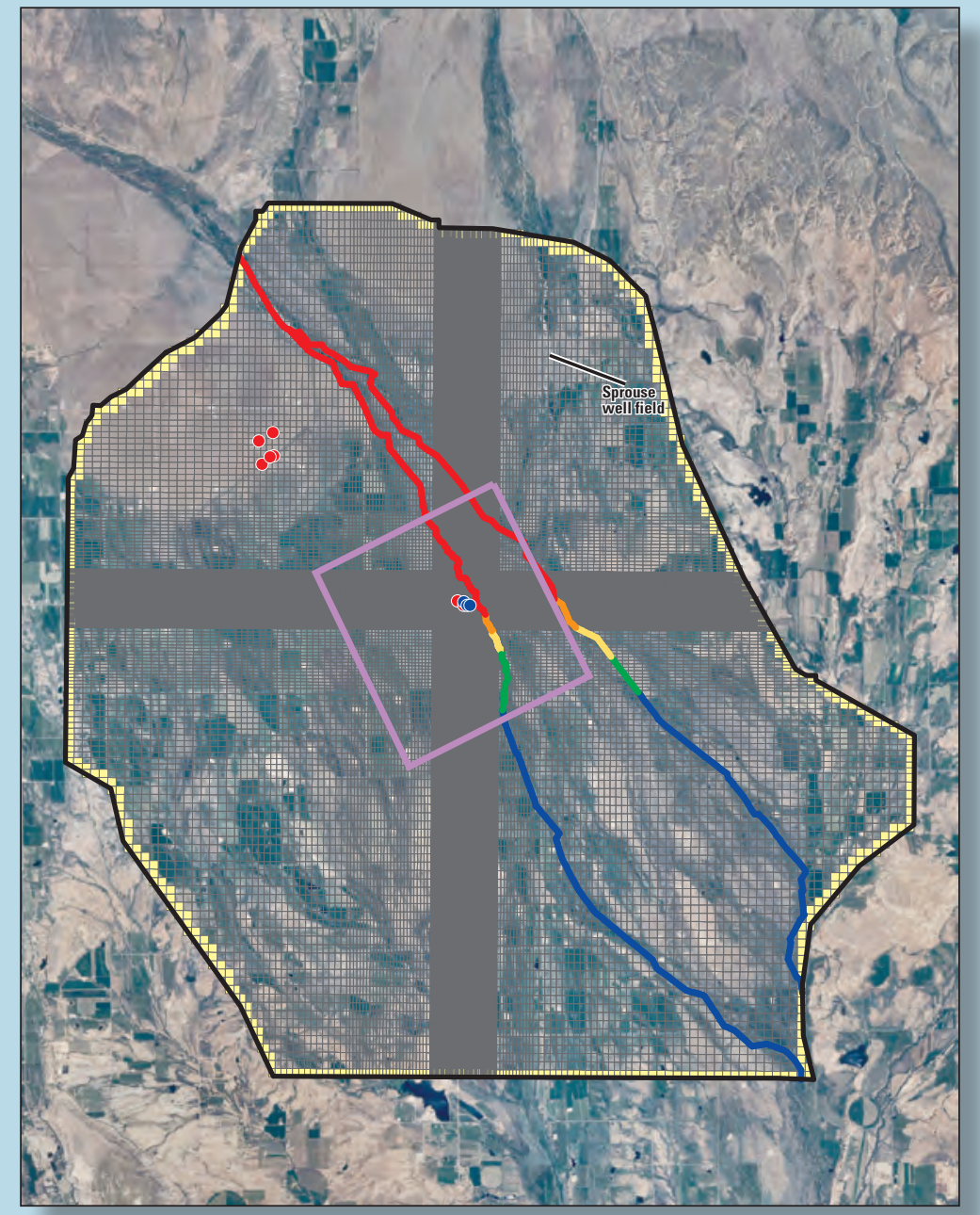

Prepared in cooperation with Roosevelt City, the Utah Department of Natural

Resources, and the Ute Indian Tribe

Scientific Investigations Report 2011-5044 
Cover: Map showing grid, location of active cells, and boundary conditions in layers 1 and 2 in the groundwater flow model, Roosevelt Valley, Utah. 


\section{Assessment of Groundwater/Surface- Water Interaction and Simulation of Potential Streamflow Depletion Induced by Groundwater Withdrawal, Uinta River near Roosevelt, Utah}

By P.M. Lambert, T. Marston, B.A. Kimball, and B.J. Stolp

Prepared in cooperation with Roosevelt City, the Utah Department of Natural

Resources, and the Ute Indian Tribe

Scientific Investigations Report 2011-5044 


\section{U.S. Department of the Interior \\ KEN SALAZAR, Secretary \\ U.S. Geological Survey \\ Marcia K. McNutt, Director}

\section{U.S. Geological Survey, Reston, Virginia: 2011}

For more information on the USGS - the Federal source for science about the Earth, its natural and living resources, natural hazards, and the environment, visit http://www.usgs.gov or call 1-888-ASK-USGS

For an overview of USGS information products, including maps, imagery, and publications, visit http://www.usgs.gov/pubprod

To order this and other USGS information products, visit http://store.usgs.gov

Any use of trade, product, or firm names is for descriptive purposes only and does not imply endorsement by the U.S. Government.

Although this report is in the public domain, permission must be secured from the individual copyright owners to reproduce any copyrighted materials contained within this report.

Suggested citation:

Lambert, P.M., Marston, T., Kimball, B.A., and Stolp, B.J., 2011, Assessment of groundwater/surface-water interaction and simulation of potential streamflow depletion induced by groundwater withdrawal, Uinta River near Roosevelt, Utah: U.S. Geological Survey Scientific Investigations Report 2011-5044, 47 p. 


\section{Contents}

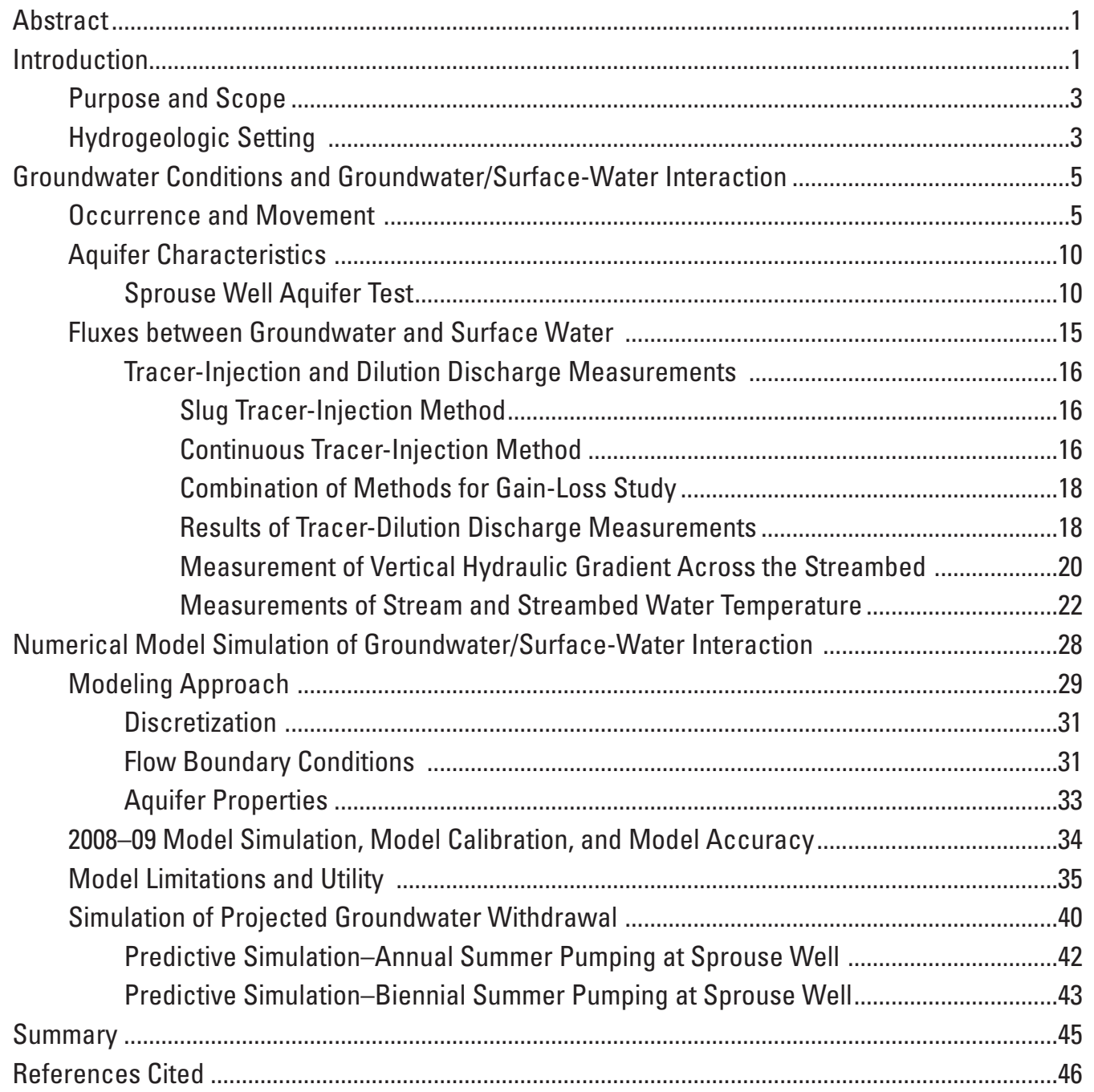

\section{Figures}

1 Map showing location of study area, Roosevelt Valley, Utah ........................................ 2

2 Map showing location of the Sprouse well field adjacent to the West Channel of the Uinta River, Roosevelt Valley, Utah ..................................................................... 4

3 Diagram showing conceptualized study area hydrologic setting and groundwater system, Roosevelt Valley, Utah ................................................................................. 5

4 Map showing altitude of $A$, water-table in the glacial outwash aquifer, and $B$, potentiometric surface of the Duchesne River Formation, and general directions of groundwater flow, Roosevelt Valley, Utah ....................................................................... 7

5 Map showing altitude of the water-table in the glacial outwash aquifer in the study area, August 2008, and general direction of groundwater flow, Roosevelt Valley, Utah 
6 Graphs showing water-level fluctuations in selected wells completed in glacial outwash in the study area and weekly moving average stage in the West Channel of the Uinta River near the Bench Canal, Roosevelt Valley, Utah .....

7 Graphs showing measured water levels at six observation wells resulting from pumping at the Sprouse well and water levels determined from the Neuman aquifer-response solution, October and November 2008, Roosevelt Valley, Utah ......... 14

8 Diagram showing interaction of groundwater and surface water in a $A$, a gaining stream and $B$, a losing stream

9 Diagram showing approach to $A$, slug tracer-dilution discharge measurements and $B$, continuous tracer-injection discharge measurements, Roosevelt Valley, Utah

10 Graph showing variation in bromide concentration with time for slug injection at site 4A, West Channel of the Uinta River, Roosevelt Valley, Utah, November 2008 ....... 17

11 Map showing location of tracer injection and dilution discharge measurement reaches, West Channel of the Uinta River, Roosevelt Valley, Utah

12 Graph showing variation in chloride concentration and relative river stage with time, West Channel of the Uinta River, Utah, November 2009

13 Diagram showing $A$, an installed instream piezometer with temperature sensor and $B$, photograph of pz-7 with manometer board attached, Roosevelt Valley, Utah ...22

14 Map showing direction of vertical hydraulic gradient measured at instream piezometers in the West Channel of the Uinta River, Roosevelt Valley, Utah . .23

15 Diagram showing thermal and hydraulic responses to two possible streambed conditions: $A$, perennial stream, gaining reach and $B$, perennial stream, losing reach

16 Graph showing water temperature in the West Channel of the Uinta River and instream piezometers, Roosevelt Valley, Utah

17 Graph showing daily stream stage in the West Channel of the Uinta River near the Bench Canal, Utah, and stream temperature and water temperature in piezometer pz-4, Roosevelt Valley, Utah

18 Map showing grid, location of active cells, and boundary conditions in layers 1 and 2 in the groundwater flow model, Roosevelt Valley, Utah

19 Graph showing simulated river stage at head-dependent river cells and input function used to adjust head with time from initial values at specified-head boundaries in the groundwater flow model, Roosevelt Valley, Utah

20 Graph showing weekly groundwater withdrawals from production wells and the Sprouse well incorporated in the 2008-2009 groundwater flow model simulation, Roosevelt Valley, Utah

21 Map showing model-computed altitude of water table in model layer 1 and the difference between water levels measured in August 2008 at wells in the glacial outwash aquifer and model-computed water levels representing August 2008, Roosevelt Valley, Utah

22 Map showing final distribution of hydraulic-conductivity values for model layer 1 in the groundwater flow model, Roosevelt Valley, Utah

23 Graph showing model-computed and measured water-level changes at monitoring wells in the Sprouse well field, Roosevelt Valley, Utah

24 Graph showing model-computed net gain to or loss from the West Channel of the Uinta River, Utah, simulated from August 1, 2008-July 31, 2009, Roosevelt Valley, Utah 
25 Map showing model-computed drawdown in layer 1 after 10 years based on simulation of potential annual summer groundwater withdrawal from the Sprouse well, Roosevelt Valley, Utah

26 Graphs showing model-computed changes for the 9th and 10th years of a 10-year simulation in 1 , storage in the glacial outwash aquifer represented by model layer 1, 2, flow to or from the West Channel of the Uinta River, 3, flow from the Duchesne River Formation represented by model layer 2, and 4, flow at the Zonebudget boundary resulting from $A$, simulated annual groundwater withdrawal from the Sprouse well, and $B$, simulated biennial groundwater withdrawal from the Sprouse well, Roosevelt Valley, Utah

\section{Tables}

1 Water levels in selected wells, Roosevelt Valley, Utah.................................................

2 Construction information for the Sprouse well and six observation wells used during the aquifer test, October and November 2008, Roosevelt Valley, Utah.

3 Observation-well characteristics and results of the Neuman aquifer-response solution to the Sprouse well aquifer test, October and November 2008, Roosevelt Valley, Utah.

4 Results of slug tracer-injection discharge measurements in selected reaches of the West Channel of the Uinta River, November 2008, Roosevelt Valley, Utah........... 20

5 Results of combined slug and continuous tracer injections in selected reaches of the West Channel of the Uinta River, November 2009, Roosevelt Valley, Utah........... 20

6 Vertical hydraulic gradients measured at piezometers in the West Channel of the Uinta River, Roosevelt Valley, Utah.

7 Comparison of model-computed net gaining/losing conditions and observed gaining/losing conditions in the West Channel of the Uinta River, Roosevelt Valley, Utah.

8 Summary of model-computed depletions of streamflow based on the simulation of potential annual summer groundwater withdrawal from the Sprouse well, Roosevelt Valley, Utah.

9 Summary of model-computed depletions of streamflow based on the simulation of biennial summer groundwater withdrawal from the Sprouse well, Roosevelt Valley, Utah. 


\section{Conversion Factors}

\begin{tabular}{|c|c|c|}
\hline Multiply & By & To obtain \\
\hline \multicolumn{3}{|c|}{ Length } \\
\hline inch (in.) & 2.54 & centimeter $(\mathrm{cm})$ \\
\hline inch (in.) & 25.4 & millimeter (mm) \\
\hline foot (ft) & 0.3048 & meter (m) \\
\hline yard (yd) & 0.9144 & meter (m) \\
\hline mile (mi) & 1.609 & kilometer (km) \\
\hline \multicolumn{3}{|c|}{ Area } \\
\hline square foot $\left(\mathrm{ft}^{2}\right)$ & 0.09290 & square meter $\left(\mathrm{m}^{2}\right)$ \\
\hline \multicolumn{3}{|c|}{ Flow rate } \\
\hline acre-foot per year (acre-ft/yr) & 1,233 & cubic meter per year $\left(\mathrm{m}^{3} / \mathrm{yr}\right)$ \\
\hline foot per day (ft/d) & 0.3048 & meter per day $(\mathrm{m} / \mathrm{d})$ \\
\hline cubic foot per second $\left(\mathrm{ft}^{3} / \mathrm{s}\right)$ & 0.02832 & cubic meter per second $\left(\mathrm{m}^{3} / \mathrm{s}\right)$ \\
\hline cubic foot per day $\left(\mathrm{ft}^{3} / \mathrm{d}\right)$ & 0.02832 & cubic meter per day $\left(\mathrm{m}^{3} / \mathrm{d}\right)$ \\
\hline gallon per minute (gal/min) & 0.06309 & liter per second (L/s) \\
\hline \multicolumn{3}{|c|}{ Transmissivity* } \\
\hline foot squared per day $\left(\mathrm{ft}^{2} / \mathrm{d}\right)$ & 0.09290 & meter squared per day $\left(\mathrm{m}^{2} / \mathrm{d}\right)$ \\
\hline \multicolumn{3}{|c|}{ Volume } \\
\hline acre-foot (acre-ft) & 1,233 & cubic meter $\left(\mathrm{m}^{3}\right)$ \\
\hline
\end{tabular}

Temperature in degrees Celsius $\left({ }^{\circ} \mathrm{C}\right)$ may be converted to degrees Fahrenheit $\left({ }^{\circ} \mathrm{F}\right)$ as follows:

${ }^{\circ} \mathrm{F}=\left(1.8 x^{\circ} \mathrm{C}\right)+32$

Temperature in degrees Fahrenheit $\left({ }^{\circ} \mathrm{F}\right)$ may be converted to degrees Celsius $\left({ }^{\circ} \mathrm{C}\right)$ as follows:

${ }^{\circ} \mathrm{C}=\left({ }^{\circ} \mathrm{F}-32\right) / 1.8$

Vertical coordinate information is referenced to the North American Vertical Datum of 1988 (NAVD 88).

Horizontal coordinate information is referenced to the North American Datum of 1983 (NAD 83).

Altitude, as used in this report, refers to distance above the vertical datum.

*Transmissivity: The standard unit for transmissivity is cubic foot per day per square foot times foot of aquifer thickness $\left[\left(\mathrm{ft}^{3} / \mathrm{d}\right) / \mathrm{ft}^{2}\right] \mathrm{ft}$. In this report, the mathematically reduced form, foot squared per day $\left(\mathrm{ft}^{2} / \mathrm{d}\right)$, is used for convenience.

Specific conductance is given in microsiemens per centimeter at 25 degrees Celsius $(\mu \mathrm{S} / \mathrm{cm}$ at $\left.25^{\circ} \mathrm{C}\right)$.

Concentrations of chemical constituents in water are given in either milligrams per liter (mg/L) or micrograms per liter $(\mu \mathrm{g} / \mathrm{L})$. 


\title{
Assessment of Groundwater/Surface-Water Interaction and Simulation of Potential Streamflow Depletion Induced by Groundwater Withdrawal, Uinta River near Roosevelt, Utah
}

\author{
By P.M. Lambert, T. Marston, B.A. Kimball, and B.J. Stolp
}

\section{Abstract}

Roosevelt City, Utah, asserts a need for an additional supply of water to meet municipal demands and has identified a potential location for additional groundwater development at the Sprouse well field near the West Channel of the Uinta River. Groundwater is commonly hydraulically linked to surface water and, under some conditions, the pumpage of groundwater can deplete water in streams and other water bodies. In 2008, the U.S. Geological Survey, in cooperation with Roosevelt City, the Utah Department of Natural Resources, and the Ute Indian Tribe, began a study to improve understanding of the local interconnection between groundwater and surface water and to assess the potential for streamflow depletion from future groundwater withdrawals at a potential Roosevelt City development location-the Sprouse well field near the West Channel of the Uinta River.

In the study, streamflow gains and losses at the river/ aquifer boundary near the well field and changes in those conditions over time were assessed through (1) synoptic measurement of discharge in the stream at multiple sites using tracer-dilution methods, (2) periodic measurement of the vertical hydraulic gradient across the streambed, and (3) continuous measurement of stream and streambed water temperature using heat as a tracer of flow across the streambed. Although some contradictions among the results of the three assessment methods were observed, results of the approaches generally indicated (1) losing streamflow conditions on the West Channel of the Uinta River north of and upstream from the Sprouse well field within the study area, (2) gaining streamflow conditions south of and downstream from the well field, and (3) some seasonal changes in those conditions that correspond with seasonal changes in stream stage and local water-table altitudes.

A numerical groundwater flow model was developed on the basis of previously reported observations and observations made during this study, and was used to estimate potential streamflow depletion that might result from future groundwater withdrawals at the Sprouse well field. The model incorporates concepts of transient groundwater flow conditions including fluctuations in groundwater levels and storage, and the distribution of and temporal variations in gains to and losses from streamflow in the West Channel of the Uinta River near the Sprouse well field. Two predictive model simulations incorporated additional future discharge from the Sprouse well field totaling 325 acre-feet annually and biennially during summer months. Results of the predictive model simulations indicate that the water withdrawn by the additional pumping was derived initially from aquifer storage and then, with time, predominantly from streamflow depletion. By the 10th year of the predictive simulation incorporating annual summer pumping from an additional public-supply well in the Sprouse well field, the simulation results indicate that 89 percent of a future annual 325 acre-feet of discharge is derived from depletion of streamflow in the West Channel of the Uinta River. A similar result was observed in a predictive model simulating the same discharge rate but with the new well being pumped every other year.

\section{Introduction}

Groundwater is currently the source of drinking water for Roosevelt City, Utah (Horrocks Engineering, 2003), in Roosevelt Valley (fig. 1). Groundwater may be hydraulically linked to nearby surface-water resources such as the Uinta River. In many situations, surface-water bodies (lakes or streams) gain water from groundwater systems, whereas in others the surface-water body is a source of groundwater recharge. As a result, withdrawal of water from streams can deplete groundwater and pumpage of groundwater can deplete water in streams and other water bodies. These interactions may be difficult to observe, however. Local waterresource managers are in need of improved understanding of the interconnection between groundwater and surface water in Roosevelt Valley and the possible effects of future development of groundwater on surface-water resources that serve as irrigation and stock-water supplies downstream. 


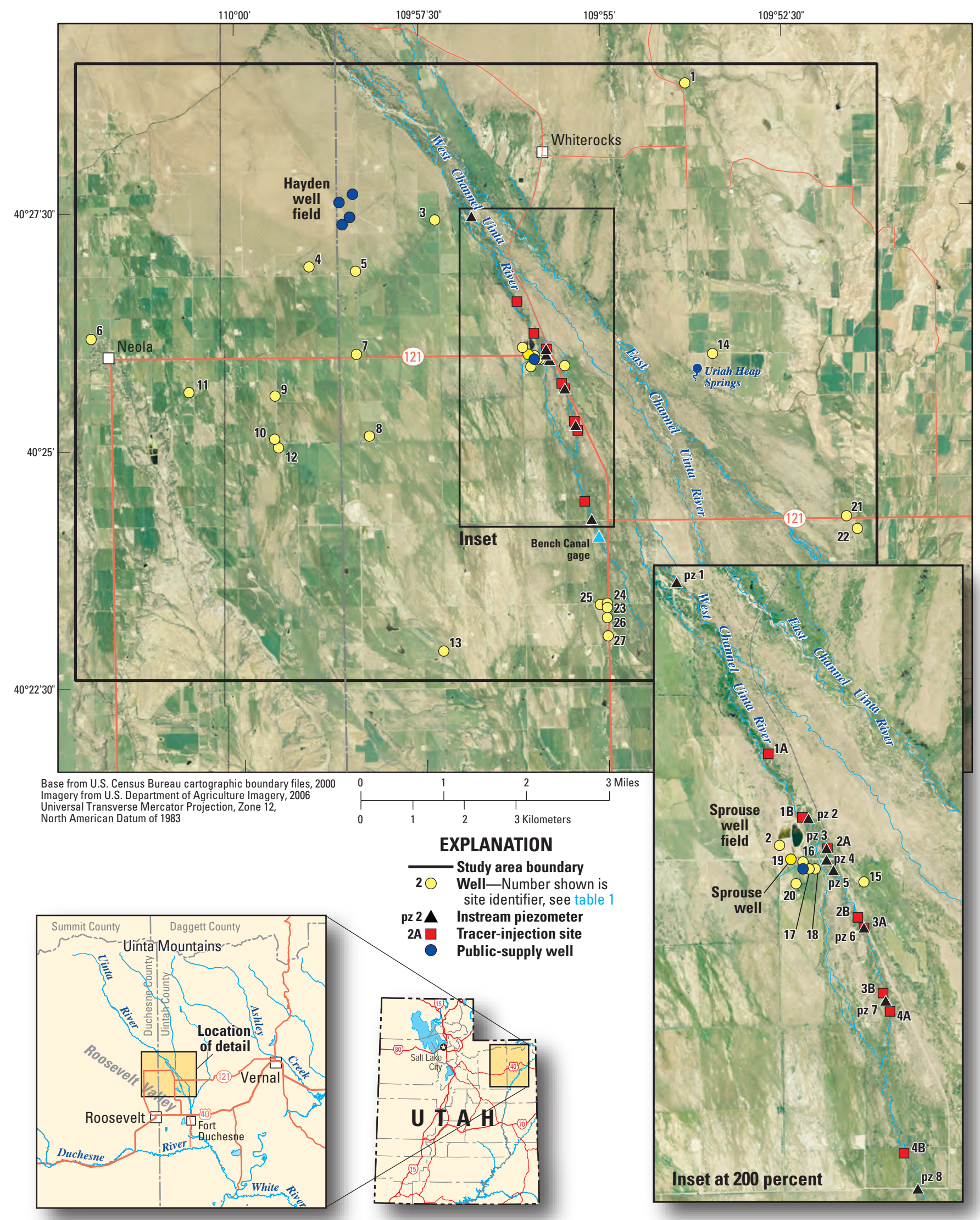

Figure 1. Location of study area, Roosevelt Valley, Utah. 
Roosevelt City asserts a need for an additional supply of water to meet municipal demands and has identified a potential location for additional groundwater development at the Sprouse well field near the West Channel of the Uinta River (figs. 1 and 2). In 2008, the U.S. Geological Survey (USGS), in cooperation with Roosevelt City, the Utah Department of Natural Resources, and the Ute Indian Tribe, as part of local groundwater management and planning assessments, began a study of potential streamflow depletion resulting from possible future groundwater withdrawals at the Sprouse well field.

The term "streamflow depletion" describes the withdrawal-induced changes in inflow to or outflow from an aquifer (Leake and Reeves, 2008). The concept was first articulated by C.V. Theis (1940), who explained that the source of water to wells is initially storage and, later, increased inflow to and (or) decreased outflow from the aquifer at stream boundaries. The objectives of this study were to assess groundwater/surfacewater conditions and interactions near the reach of the West Channel of the Uinta River adjacent to the Sprouse well field (figs. 1 and 2), and to estimate streamflow depletion that may result from possible future groundwater withdrawals in the area. Because the well field was only in the planning stages during the study period, the long-term effects of the potential withdrawals in the area could not be observed directly. Also, the hydrologic setting of the study area was not conducive to the direct measurement of groundwater/surface-water interactions. Therefore, a combination of indirect methods was used to measure groundwater movement near the stream and groundwater flow modeling was conducted to represent those conditions and estimate streamflow depletion resulting from nearby groundwater withdrawals.

Specifically, the study included observations of waterlevel conditions, groundwater withdrawals, gains and losses of streamflow in the study area, and the transfer of heat across the streambed as a tracer of groundwater movement to describe aquifer/stream interactions. It was assumed that the direction and magnitude of groundwater/surface-water interaction in the study area change with time as a function of water levels in the aquifer and stream stage. Thus, the study approach included quantifying aquifer/stream interactions from periodic and continuous field observations over time using multiple methods. Incorporating observations of gains and losses of streamflow in a groundwater flow model allowed for the (1) assessment of aquifer and streambed characteristics that define aquifer/stream interaction, and (2) simulation of potential changes in those interactions caused by groundwater withdrawals as hydrologic conditions changed with time.

\section{Purpose and Scope}

This report documents the development of conceptual and numerical models of groundwater flow and groundwater/ surface-water interaction near the Uinta River northeast of Roosevelt City, Utah (fig. 1). The report also describes the application of a numerical groundwater flow model to estimate potential streamflow depletion that could be induced by groundwater withdrawals at the Sprouse well field adjacent to the West Channel of the Uinta River (fig. 2).

The assessment documented in this report includes:

1. Measurement and assessment of general water-level conditions and pattern of groundwater flow in the vicinity of the study area;

2. Synoptic measurement and assessment of the stream/ aquifer interaction in the study area (that is, identification of gaining or losing stream reaches and quantification of those gains or losses);

3. Continuous monitoring of stream/aquifer interaction over the course of 1 year, including water-level observations and stream and streambed temperature measurements;

4. Estimation of local aquifer properties at the Sprouse well field from a multi-day aquifer test;

5. Synthesis of data collected in (1)-(4) above in a numerical groundwater flow model; and

6. Application of the model to assess stream/aquifer interaction, including potential streamflow depletion as a result of future groundwater withdrawals.

The report includes a discussion of the limitations of the model as an accurate representation of the study-area groundwater flow system and as a tool for predicting the effects of hydrologic stresses, including pumping.

\section{Hydrogeologic Setting}

The study area (fig. 1) lies within the northern Uinta Basin, a structural feature resulting from erosion of soft rocks, mainly of Tertiary age, which are folded into an east-trending syncline (Hood and Fields, 1978). The northern half of the Uinta Basin is bordered on the north by the Uinta Mountains and on the south by the Duchesne River.

The study-area setting (fig. 3) is characterized by moderately sloping alluvial fans and gently sloping river terraces transitioning northward into high-elevation bench lands (Horrocks Engineering, 2003). The study area and the Sprouse well field (figs. 1 and 2) overlie coarse sand-andgravel deposits of a large, moderately sloping glacial outwash plain west of the Uinta River. These sediments constitute the principal aquifer of the northern Uinta Basin (Hood, 1976), the principal source of public-supply water for Roosevelt City. The outwash sediments are overlain by coarse alluvial gravels. The outwash is underlain by shales and sandstones of the Duchesne River Formation (Hood, 1976).

The Uinta River, a tributary of the Duchesne River, flows south through the study area. In most of the area, flow in the Uinta River is split between a west and east river channel (fig. 1). Water is diverted from the Uinta River to canals for local irrigation stock water both outside and within the study area. 


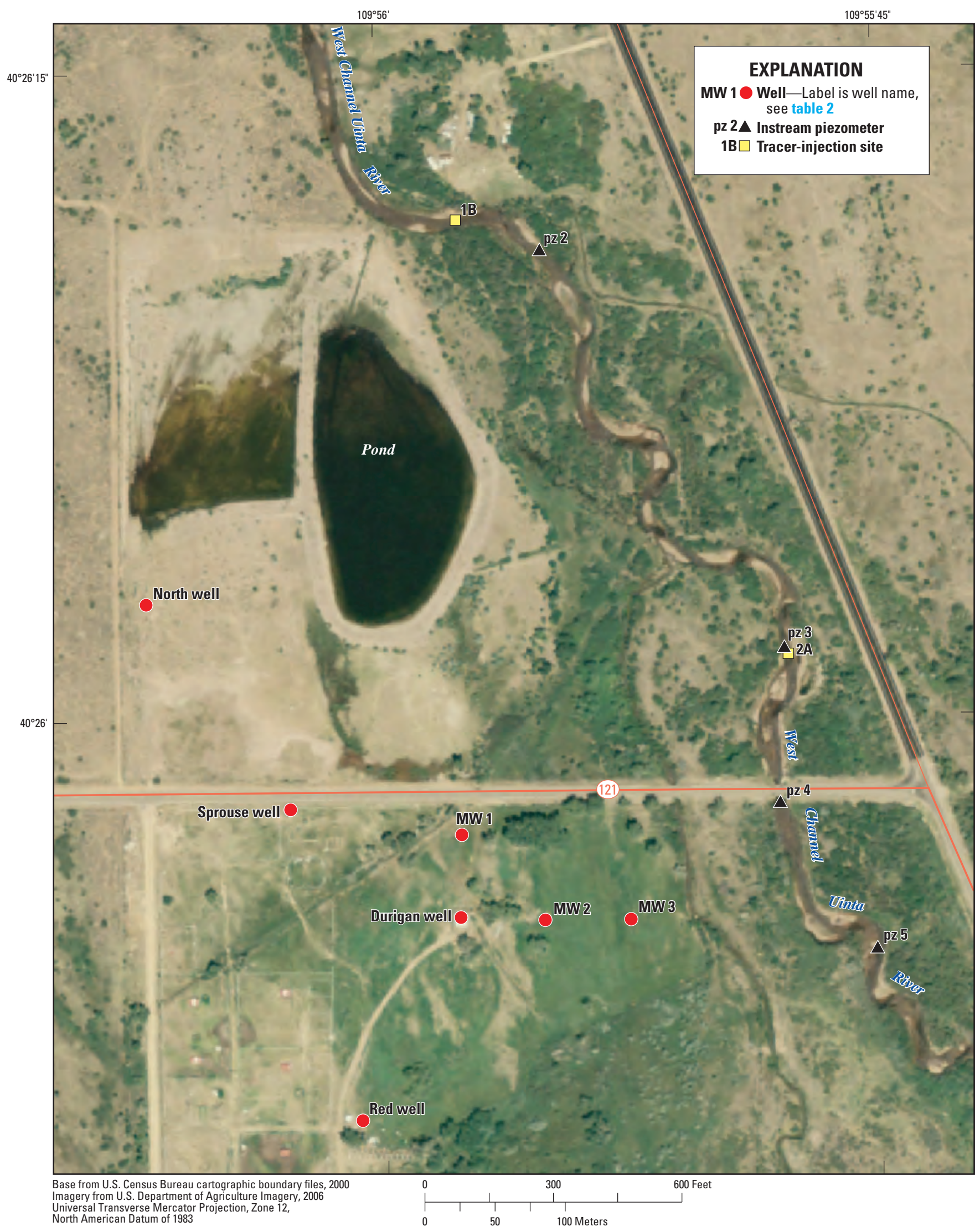

Figure 2. Location of the Sprouse well field adjacent to the West Channel of the Uinta River, Roosevelt Valley, Utah. 


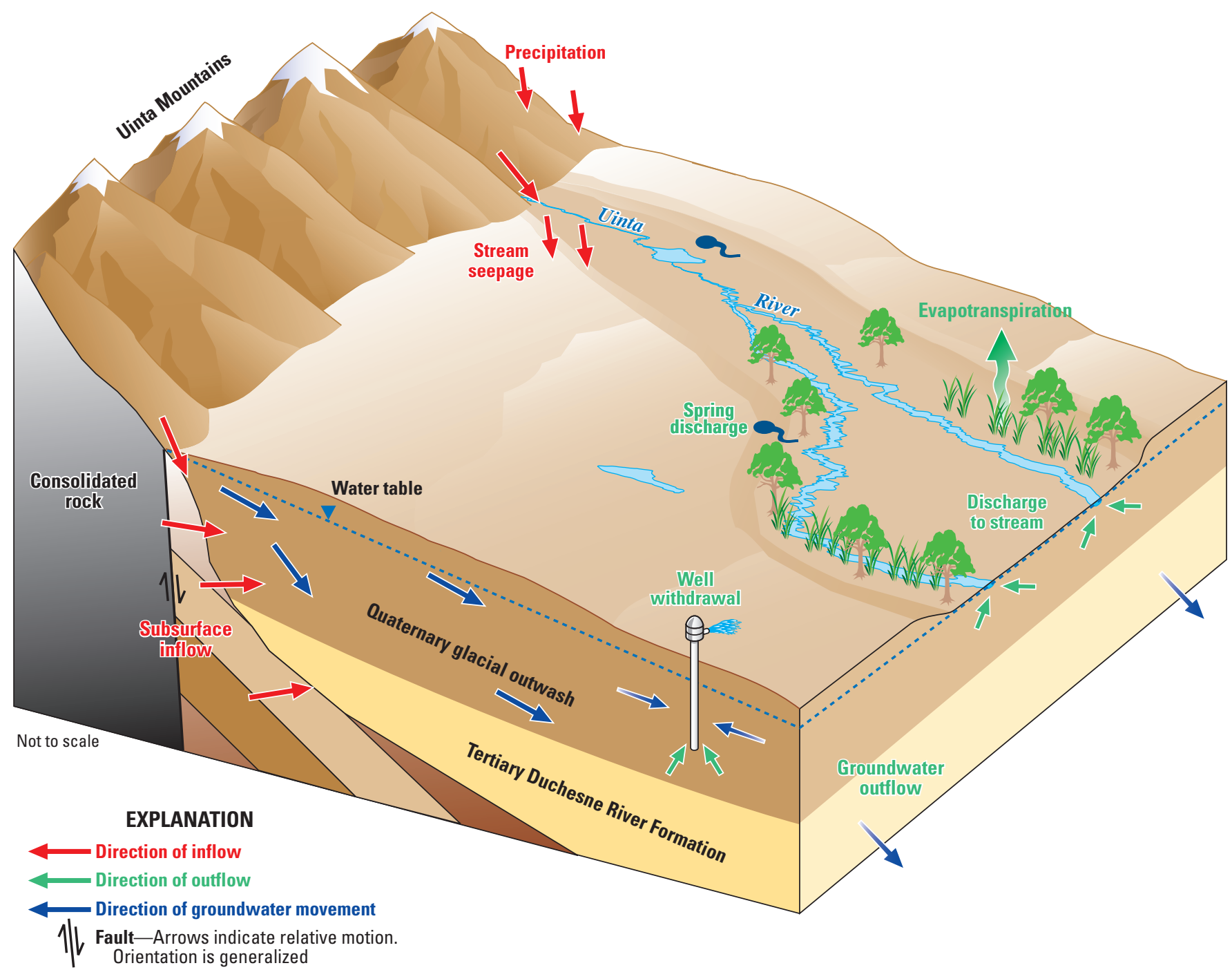

Figure 3. Conceptualized study area hydrologic setting and groundwater system, Roosevelt Valley, Utah.

The Sprouse well field is located near the center of the study area, adjacent to the West Channel of the Uinta River (fig. 2). Surface water also occurs seasonally in a small pond north of the Sprouse well field (fig. 2). The pond was originally constructed to receive and hold water diverted from the river for recreational purposes. Currently (2009-10), no water is diverted to the structure. The standing water that is observed periodically in the pond is likely a surface expression of the local water table.

\section{Groundwater Conditions and Groundwater/Surface-Water Interaction}

\section{Occurrence and Movement}

Groundwater in Roosevelt Valley and within the study area is found principally in a Quaternary-age glacial outwash shallow aquifer composed of unconsolidated rocks and sediment from various sources in the Uinta Mountains and from uplands to the north. Unconfined groundwater conditions in the glacial outwash aquifer likely persist in much of the area surrounding the Uinta River, from the south slope of the Uinta Mountains in the north to the southernmost reaches of the unit near Fort Duchesne, Utah. Based on drillers' log descriptions, the geometry of the glacial outwash within the study area approximates a wedge of sediment whose thickness ranges from about $50 \mathrm{ft}$ in the southern part of the study area to about $300 \mathrm{ft}$ in the northern part.

The glacial outwash aquifer is underlain regionally and within the study area by the Duchesne River Formation. The Duchesne River Formation is reported to include a variety of lithologies regionally but is mostly shale with sandstone interbeds, which commonly result in confined groundwater conditions (Hood, 1976). The formation is slightly to strongly fractured regionally, which results in enhanced permeability, particularly in highly fractured areas. The strongly fractured 
areas of the formation are west of Roosevelt. Hood (1976) reports limited fracturing in the area northeast of Roosevelt, although some vertical fracturing is inferred in association with the occurrence of gilsonite (a solid black hydrocarbon) dikes in the area (Hood and Fields, 1978). In general, properties of the Duchesne River Formation reported in previous studies (Hood, 1976; Hood and Fields, 1978) indicate that it is substantially less permeable than the overlying glacial outwash in the vicinity of the study area, and likely acts as an aquiclude with limited groundwater interaction between it and the overlying glacial outwash aquifer.

Recharge to the glacial outwash aquifer occurs regionally as underflow from the adjacent mountain front and at the surface as infiltration from streamflow, irrigation water, and precipitation. Recharge derived from precipitation on the Uinta Mountains enters the groundwater system as underflow at the margins of the valley or by seepage from streams entering the basin. Applied irrigation water and precipitation recharge the groundwater system directly, through unconsolidated sediments.

Groundwater moves southeast through the valley and the study area toward the Duchesne River and generally parallel to the Uinta River. Water-level altitudes in the glacial outwash aquifer in the Roosevelt Valley region (fig. 4a) were defined previously by Hood and Fields (1978) from data collected prior to 1976. The water table in the study area was defined on the basis of measurements made in 27 wells in August 2008 and indicates a similar pattern of southeasterly groundwater movement (fig. 5 and table 1). Precipitation at the Chepeta and Mosby Mountain weather stations, located north of the study area in the Uinta Mountains, for the 2009 water year were within 1 percent of 30-year average values (Natural Resources Conservation Service, 2010.). Although historical waterlevel data available to provide a context for 2008 hydrologic conditions in the study area are limited, it can be assumed that water-level conditions observed during the study period (fig. 5) are not the result of recharge derived from substantially below- or above-average precipitation.

Previous studies mentioned by Hood and Fields (1978) indicate the presence of vertical hydraulic gradients between the glacial outwash aquifer and the underlying Duchesne River Formation in Roosevelt Valley and within the study area. Contoured water-level data for the glacial outwash aquifer and the Duchesne River Formation collected prior to 1976 (fig. 4b) (Hood and others, 1976; Hood and Fields, 1978) indicate a downward head gradient in the vicinity of the Sprouse well field, with a difference in groundwater altitude between the glacial outwash aquifer and the underlying formation of approximately $75 \mathrm{ft}$. The data indicate that the downward gradient persists in the southern half of the study area, whereas a slight upward head gradient is present in the northern part of the study area. The occurrence of these gradients indicates a potential for movement of groundwater between the two formations. Interaction between the two layers may be minor, because of the low permeability of the Duchesne River Formation.
Seasonal water-level fluctuations were observed in wells in the glacial outwash aquifer during this study (fig. 6). These data indicate that, generally, water levels in the glacial outwash aquifer within the study area peaked in late spring or early summer and were lowest in mid winter. In most wells, water levels fluctuated less than $+/-5 \mathrm{ft}$. High groundwater levels in late spring and early summer are likely the result of increased recharge from spring snowmelt, and associated runoff and high streamflows. Water levels generally declined in late summer and winter, likely in response to groundwater pumping and reduced flow in losing reaches of the river.

Discharge from the groundwater system occurs by seepage to streams, canals, and springs; evapotranspiration; and withdrawal from wells. Most discharge occurs along the southern margin of the glacial outwash aquifer. Hood (1976) reports that water-level contours curve around the Uinta River and the Duchesne River east of Roosevelt City, indicating a discharge area for the glacial outwash aquifer. Canals in this area also may be points of discharge for the glacial outwash aquifer.

The Uriah Heap Spring system is located $1.65 \mathrm{mi}$ east of the Sprouse well field. These springs discharge at an altitude of 5,675 ft and have an estimated average discharge of $3.5 \mathrm{ft}^{3} / \mathrm{s}$ on the basis of annual measurements made from 1985 to 1987. Another spring system, known locally as Provo Dick Spring, associated with the Whiterocks Fish Hatchery, is located beyond the northern boundary of the study area, approximately $3.5 \mathrm{mi}$ northwest of the Sprouse well field. These springs discharge at an altitude of $6,150 \mathrm{ft}$ and have an estimated seasonal range of discharge from 4.5 to $8.3 \mathrm{ft}^{3} / \mathrm{s}$. Several smaller springs are present along the banks of incised stream channels in the glacial outwash throughout the area.

Groundwater discharge by evapotranspiration occurs in Roosevelt Valley in areas of riparian vegetation that includes greasewood, willow, Russian olive, and some subirrigated pasture (Hood and Fields, 1978). Land-cover mapping by the USGS Southwest Regional Gap Analysis Project indicates that phreatophytes in the study area generally are limited to river corridors (U.S. Geological Survey, 2004).

Public-supply wells discharge groundwater at the Hayden well field (fig. 1) and the Sprouse well field (figs. 1 and 2). There is one active public-supply well, the Durigan well, in the Sprouse well field and several unused wells within $1,500 \mathrm{ft}$ of the West Channel of the Uinta River (fig. 2). The Sprouse well (fig. 2), originally developed as an irrigation well, is currently unused and is being assessed by Roosevelt City for possible conversion to a production well for public water supply. Both the Durigan public-supply well and the Sprouse well are completed in glacial outwash sediments. The wells in the Hayden well field are operated continuously, with peak demand occurring in the summer months. Pumpage from the two municipal well fields is documented, with a combined withdrawal from August 2008 to August 2009 of approximately 2,200 acre-ft/yr. Most of the withdrawal during that time was from the Hayden well field. 


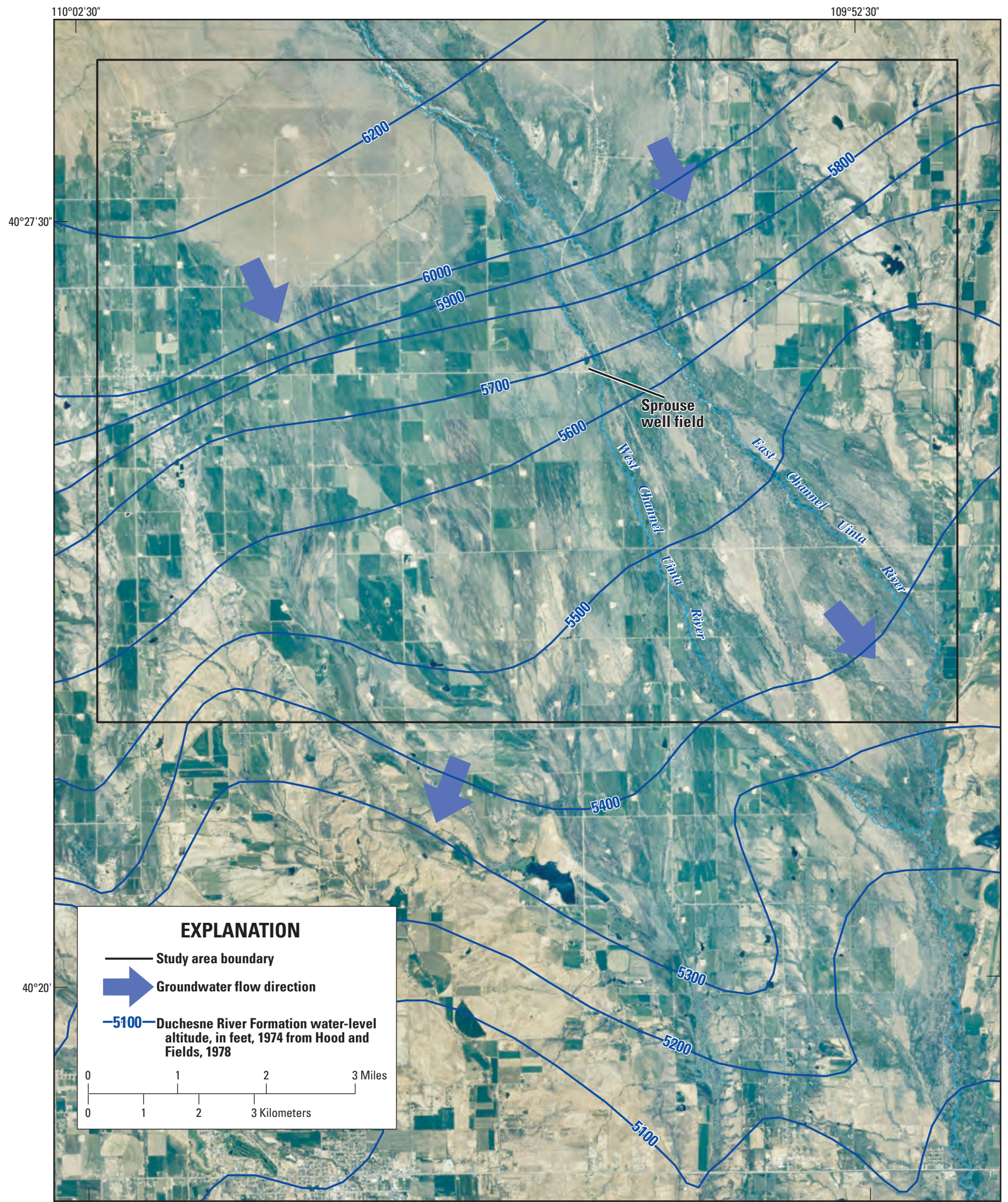

Base from U.S. Census Bureau cartographic boundary files, 2000

From Hood and Fields, 1978

Imagery from U.S. Department of Agriculture Imagery, 2009

Water Level Data form Utah DNR Tech. Pub. No. 62, 1978

Universal Transverse Mercator Projection, Zone 12,

North American Datum of 1983

Figure 4. Altitude of $A$, water-table in the glacial outwash aquifer, and $B$, potentiometric surface of the Duchesne River Formation, and general directions of groundwater flow, Roosevelt Valley, Utah. 


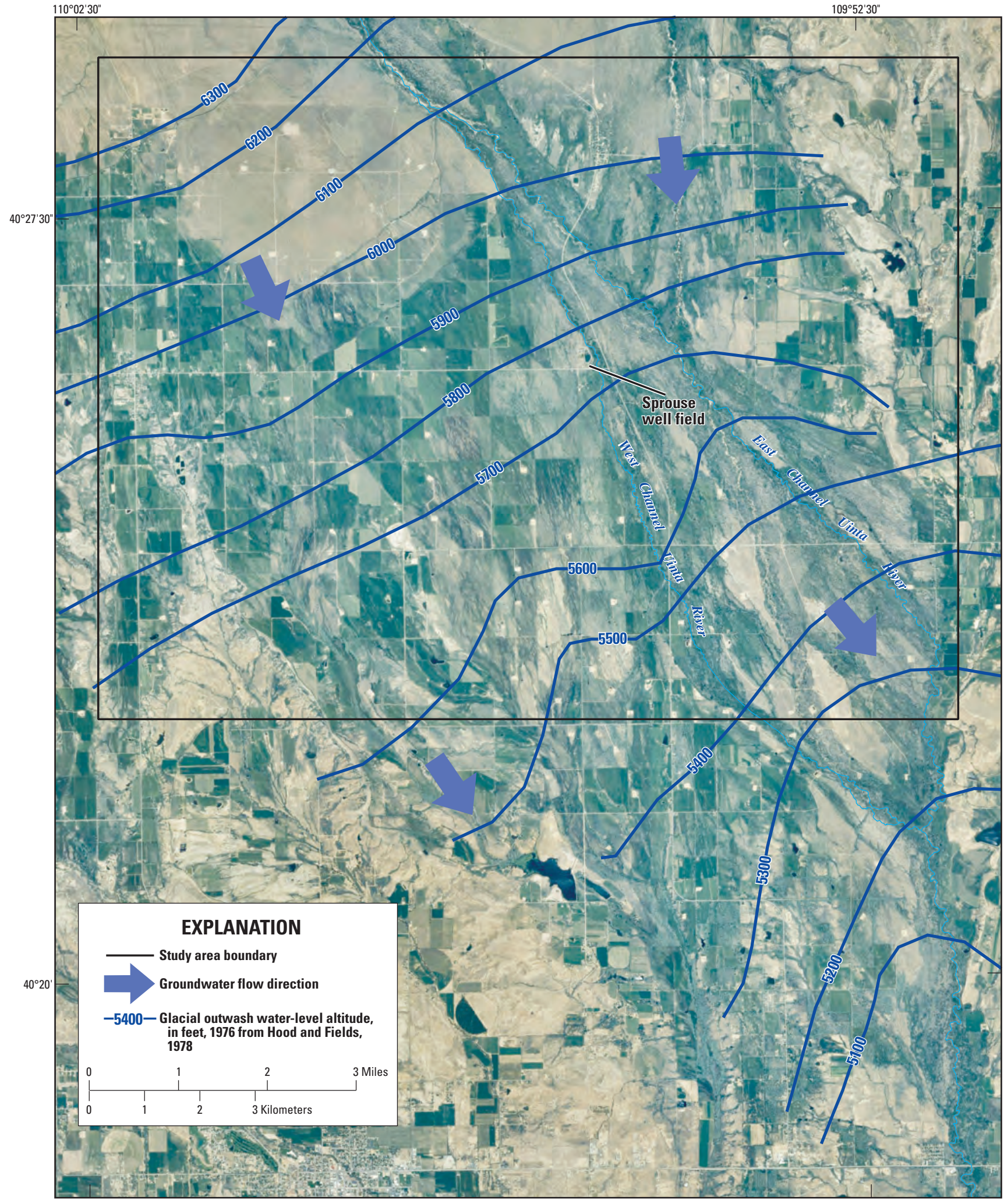

Base from U.S. Census Bureau cartographic boundary files, 2000

Imagery from U.S. Department of Agriculture Imagery, 2009

Water Level Data form Utah DNR Tech. Pub. No. 62, 1978

Universal Transverse Mercator Projection, Zone 12,

North American Datum of 1983

Figure 4. Altitude of $B$, potentiometric surface of the Duchesne River Formation, and general directions of groundwater flow, Roosevelt Valley, Utah.-Continued 
Table 1. Water levels in selected wells, Roosevelt Valley, Utah.

[Site ID, site identification number; - , no data]

\begin{tabular}{|c|c|c|c|c|c|}
\hline Site ID & Well name & $\begin{array}{l}\text { Well } \\
\text { depth } \\
\text { (feet) }\end{array}$ & $\begin{array}{c}\text { Altitude of } \\
\text { land surface } \\
\text { (feet) }\end{array}$ & Date & $\begin{array}{l}\text { Water level, } \\
\text { feet below } \\
\text { land surface }\end{array}$ \\
\hline 1 & U(A-1-1)16ccb-1 & 45 & 6,160 & $8 / 20 / 08$ & 4.71 \\
\hline \multirow[t]{6}{*}{2} & U(A-1-1)31сcс-1 & 58 & $5,795.9$ & $10 / 30 / 08$ & 10.99 \\
\hline & & & & $1 / 22 / 09$ & 11.58 \\
\hline & & & & $3 / 4 / 09$ & 10.02 \\
\hline & & & & $4 / 28 / 09$ & 9.22 \\
\hline & & & & $6 / 16 / 09$ & 8.00 \\
\hline & & & & $8 / 27 / 09$ & 10.78 \\
\hline 3 & U(B-1-1)26ada-1 & 110 & 5,988 & $8 / 20 / 08$ & 6.65 \\
\hline 4 & $\mathrm{U}(\mathrm{B}-1-1) 27 \mathrm{cdd}-1$ & 40 & 6,035 & $8 / 21 / 08$ & 19.60 \\
\hline 5 & U(B-1-1)27ddd-1 & 71 & 5,995 & 8/19/08 & 15.31 \\
\hline \multirow[t]{7}{*}{6} & U(B-1-1)31ddb-1 & 388 & 6,055 & $8 / 21 / 08$ & 5.10 \\
\hline & & & & $9 / 29 / 08$ & 4.86 \\
\hline & & & & $1 / 22 / 09$ & 8.26 \\
\hline & & & & $3 / 4 / 09$ & 8.28 \\
\hline & & & & $4 / 28 / 09$ & 5.76 \\
\hline & & & & $6 / 16 / 09$ & 3.98 \\
\hline & & & & $8 / 27 / 09$ & 6.40 \\
\hline \multirow[t]{2}{*}{7} & U(B-1-1)34ddd-1 & 32 & $5,898.1$ & $8 / 20 / 08$ & 3.62 \\
\hline & & & & $6 / 16 / 09$ & 1.25 \\
\hline \multirow[t]{7}{*}{8} & $\mathrm{U}(\mathrm{C}-1-1) 2 \mathrm{ccd}-1$ & 39 & $5,778.3$ & $8 / 20 / 08$ & 6.01 \\
\hline & & & & $9 / 29 / 08$ & 7.23 \\
\hline & & & & $1 / 23 / 09$ & 5.20 \\
\hline & & & & $3 / 4 / 09$ & 3.97 \\
\hline & & & & $4 / 28 / 09$ & 4.10 \\
\hline & & & & $6 / 16 / 09$ & 3.36 \\
\hline & & & & $8 / 27 / 09$ & 5.83 \\
\hline 9 & $\mathrm{U}(\mathrm{C}-1-1) 3 \mathrm{bcc}-1$ & 63 & 5,880 & $8 / 19 / 08$ & 5.05 \\
\hline 10 & $\mathrm{U}(\mathrm{C}-1-1) 4 \mathrm{ddd}-1$ & 26 & 5,822 & $8 / 19 / 08$ & 7.60 \\
\hline 11 & $\mathrm{U}(\mathrm{C}-1-1) 5$ add-1 & 31 & 5,935 & $8 / 19 / 08$ & 2.30 \\
\hline 12 & $\mathrm{U}(\mathrm{C}-1-1) 10 \mathrm{bbb}-1$ & 27 & 5,815 & 8/19/08 & 7.19 \\
\hline 13 & $\mathrm{U}(\mathrm{C}-1-1) 24 \mathrm{cbb}-2$ & 500 & 5,503 & $8 / 21 / 08$ & 7.01 \\
\hline 14 & $\mathrm{U}(\mathrm{D}-1-1) 4 \mathrm{baa}-1$ & 30 & 5,712 & $8 / 22 / 08$ & 1.96 \\
\hline 15 & $\mathrm{U}(\mathrm{D}-1-1) 6 a b c-1$ & - & 5,750 & $8 / 22 / 08$ & 5.27 \\
\hline \multirow[t]{7}{*}{16} & $\mathrm{U}(\mathrm{D}-1-1) 6 \mathrm{bba}-1$ & 60 & $5,783.0$ & 9/30/09 & 7.51 \\
\hline & & & & $10 / 30 / 09$ & 6.82 \\
\hline & & & & $1 / 23 / 09$ & 10.50 \\
\hline & & & & $3 / 4 / 09$ & 6.67 \\
\hline & & & & $4 / 28 / 09$ & 5.66 \\
\hline & & & & $6 / 16 / 09$ & 3.78 \\
\hline & & & & $8 / 27 / 09$ & 7.09 \\
\hline
\end{tabular}

\begin{tabular}{|c|c|c|c|c|c|}
\hline Site ID & Well name & $\begin{array}{l}\text { Well } \\
\text { depth } \\
\text { (feet) }\end{array}$ & $\begin{array}{c}\text { Altitude of } \\
\text { land surface } \\
\text { (feet) }\end{array}$ & Date & $\begin{array}{c}\text { Water level, } \\
\text { feet below } \\
\text { land surface }\end{array}$ \\
\hline \multirow[t]{7}{*}{17} & U(D-1-1)6bba-2 & 60 & $5,776.5$ & 9/30/09 & 5.07 \\
\hline & & & & $10 / 30 / 09$ & 4.27 \\
\hline & & & & $1 / 22 / 09$ & 8.98 \\
\hline & & & & $3 / 4 / 09$ & 4.14 \\
\hline & & & & $4 / 28 / 09$ & 3.33 \\
\hline & & & & 6/16/09 & 2.34 \\
\hline & & & & $8 / 26 / 09$ & 5.49 \\
\hline \multirow[t]{7}{*}{18} & U(D-1-1)6bba-3 & 60 & $5,775.5$ & 9/30/09 & 5.03 \\
\hline & & & & $10 / 30 / 08$ & 4.29 \\
\hline & & & & $1 / 22 / 09$ & 6.98 \\
\hline & & & & $3 / 4 / 09$ & 3.99 \\
\hline & & & & $4 / 28 / 09$ & 3.44 \\
\hline & & & & 6/16/09 & 2.76 \\
\hline & & & & $8 / 26 / 09$ & 5.34 \\
\hline 19 & $\mathrm{U}(\mathrm{D}-1-1) 6 \mathrm{bbb}-1$ & 161 & 5,786 & $9 / 29 / 08$ & 8.26 \\
\hline \multirow[t]{7}{*}{20} & $\mathrm{U}(\mathrm{D}-1-1) 6 \mathrm{bbc}-1$ & - & $5,771.9$ & $8 / 22 / 08$ & 9.88 \\
\hline & & & & $10 / 30 / 08$ & 5.98 \\
\hline & & & & $1 / 22 / 09$ & 9.02 \\
\hline & & & & $3 / 4 / 09$ & 5.74 \\
\hline & & & & $4 / 28 / 09$ & 4.60 \\
\hline & & & & 6/16/09 & 2.96 \\
\hline & & & & $8 / 27 / 09$ & 9.81 \\
\hline \multirow[t]{8}{*}{21} & U(D-1-1)10ddd-1 & - & $5,427.3$ & $8 / 22 / 08$ & 7.96 \\
\hline & & & & $9 / 29 / 08$ & 8.87 \\
\hline & & & & $11 / 17 / 08$ & 8.66 \\
\hline & & & & $1 / 22 / 09$ & 8.18 \\
\hline & & & & $3 / 5 / 09$ & 7.09 \\
\hline & & & & $4 / 28 / 09$ & 7.02 \\
\hline & & & & $6 / 16 / 09$ & 1.29 \\
\hline & & & & $8 / 28 / 09$ & 8.15 \\
\hline \multirow[t]{8}{*}{22} & U(D-1-1)14bbc-1 & 230 & 5,408 & $8 / 22 / 08$ & 2.95 \\
\hline & & & & $9 / 29 / 08$ & 2.64 \\
\hline & & & & $11 / 17 / 08$ & 2.29 \\
\hline & & & & $1 / 22 / 09$ & 3.28 \\
\hline & & & & $3 / 5 / 09$ & 2.23 \\
\hline & & & & $4 / 28 / 09$ & 2.67 \\
\hline & & & & 6/16/09 & 4.65 \\
\hline & & & & $8 / 28 / 09$ & 2.82 \\
\hline 23 & U(D-1-1)19aaa-1 & 50 & 5,489 & $8 / 21 / 08$ & 2.82 \\
\hline 24 & U(D-1-1)19aaa-2 & 47 & 5,491 & $8 / 21 / 08$ & 3.68 \\
\hline
\end{tabular}


Table 1. Water levels in selected wells, Roosevelt Valley, Utah. -Continued

\begin{tabular}{|c|c|c|c|c|c|}
\hline Site ID & Well name & $\begin{array}{l}\text { Well } \\
\text { depth } \\
\text { (feet) }\end{array}$ & $\begin{array}{c}\text { Altitude of } \\
\text { land surface } \\
\text { (feet) }\end{array}$ & Date & $\begin{array}{l}\text { Water level, } \\
\text { feet below } \\
\text { land surface }\end{array}$ \\
\hline \multirow[t]{8}{*}{25} & U(D-1-1)19aaa-3 & 55 & $5,501.4$ & $8 / 27 / 08$ & 5.25 \\
\hline & & & & 9/29/08 & 3.64 \\
\hline & & & & $11 / 17 / 08$ & 4.38 \\
\hline & & & & $1 / 22 / 09$ & 4.55 \\
\hline & & & & $3 / 5 / 09$ & 4.21 \\
\hline & & & & $4 / 28 / 09$ & 3.17 \\
\hline & & & & 6/16/09 & 3.03 \\
\hline & & & & 8/28/09 & 3.93 \\
\hline 26 & U(D-1-1)19aad-1 & 50 & 5,491 & $8 / 21 / 08$ & 13.82 \\
\hline \multirow[t]{8}{*}{27} & U(D-1-1)19add-2 & 67 & 5,480 & $8 / 21 / 08$ & 12.47 \\
\hline & & & & $9 / 29 / 08$ & 13.34 \\
\hline & & & & $11 / 17 / 08$ & 12.94 \\
\hline & & & & $1 / 22 / 09$ & 14.43 \\
\hline & & & & $3 / 5 / 09$ & 14.85 \\
\hline & & & & $4 / 28 / 09$ & 11.89 \\
\hline & & & & 6/16/09 & 11.16 \\
\hline & & & & 8/28/09 & 13.15 \\
\hline
\end{tabular}

\section{Aquifer Characteristics}

Regionally, the hydraulic conductivity of the glacial outwash aquifer has been estimated to vary from 2 to 1,800 $\mathrm{ft} / \mathrm{d}$ (Hood, 1976). As previously noted, the underlying Duchesne River Formation is substantially less permeable than the outwash. Hood (1976) reported that the horizontal hydraulic conductivity of the Duchesne River Formation, determined from laboratory analyses of 19 samples collected in the region, ranged from 0.000033 to $3.28 \mathrm{ft} / \mathrm{d}$. Hood (1976) also reported a range of horizontal hydraulic conductivity from 0.3 to $1.3 \mathrm{ft} / \mathrm{d}$ computed from the results of aquifer tests of three wells completed in the Duchesne River Formation south of Roosevelt City. Aquifer tests have been conducted in previous investigations at wells finished in the glacial outwash at several locations within Roosevelt Valley. An aquifer test conducted at a well located about $3 \mathrm{mi}$ northeast of Neola yielded a horizontal hydraulic conductivity estimate of $70 \mathrm{ft} / \mathrm{d}$ (Hood, 1976). Aquifer tests at the Hayden well field indicated a horizontal hydraulic conductivity range of 43 to $64 \mathrm{ft} / \mathrm{d}$ (Horrocks Engineering, 2004). Analysis of drawdown data from aquifer tests at the Sprouse and Durigan wells, conducted in 2001 by Horrocks Engineering (2003), yielded horizontal hydraulic conductivity estimates ranging from 10 to $30 \mathrm{ft} / \mathrm{d}$. These aquifer tests had durations of approximately 1 to 3 days.

\section{Sprouse Well Aquifer Test}

To further characterize the groundwater system at the Sprouse well field (fig. 2), specifically hydrologic interaction with the West Channel of the Uinta River, the glacial outwash aquifer was hydraulically stressed by pumping at the Sprouse well for 264 hours (from 1:50 p.m. on October 30 to 1:45 p.m. on November 10, 2008). No other pumping occurred in the area 30 days prior to, during, or 30 days after the end of the pumping period. Response was measured at six observation wells (MW 1, MW 2, MW 3, Durigan, Red, and North wells, fig. 2), three instream piezometers (pz-3, pz-4, and pz-5, fig. 2), and in a pond north of the well field.

Discharge from the Sprouse well decreased from 1,825 to $1,492 \mathrm{gal} / \mathrm{min}$ during the pumping period. Discharge was piped $860 \mathrm{ft}$ east to an existing unlined irrigation ditch. The irrigation ditch contained water both prior to and after the completion of pumping, and the addition of Sprouse well discharge to the ditch was considered a minor change from pre-existing hydrologic conditions. The pumping rate was measured in the pipe using an ultrasonic flow meter. Specific conductance of the discharge water rose steadily from 249 to $272 \mu \mathrm{S} / \mathrm{cm}$ during the pumping period. Water levels at the Sprouse well were not measured during the aquifer test because pipe configuration blocked access to the water column.

Transducers were used to measure water pressure and temperature at the MW 1, MW 2, MW 3, and North wells; barometric pressure was measured with a transducer at the Sprouse well field. Steel-tape measurements were used to check transducer accuracy and measure water levels at the Durigan and Red wells. A manometer board was used to measure the difference between stream stage and water level at the three instream piezometers.

Aquifer lithology and conditions at the Sprouse well field were quantified from drillers' $\log$ information and water-level response to changes in barometric pressure. The Durigan and Sprouse wells were both drilled through the entire thickness of the glacial outwash; outwash thicknesses at the wells are 150 and $159 \mathrm{ft}$, respectively (table 2). Prior to pumping, the depth to water measured from land surface in the monitored wells ranged from about 6 to $12 \mathrm{ft}$. From these data, the saturated thickness of the outwash in the area affected by the aquifer test was assumed to be $150 \mathrm{ft}$. Sediment type, as described in drillers' logs for the pumped and monitoring wells, consists of sand, gravel, cobbles, and boulders; the presence of clay and silt was not noted. The glacial outwash was assigned a barometric efficiency of 0.0 , because there were no water-level fluctuations in the vented-pressure transducer record for MW 1 that correlated to barometric fluctuations. After subtracting atmospheric pressure from the absolute-pressure transducer record for North well, there were also no barometrically induced water-level fluctuations. Absence of barometric fluctuations in water levels indicates direct communication between water in the aquifer pore space and the atmosphere. 


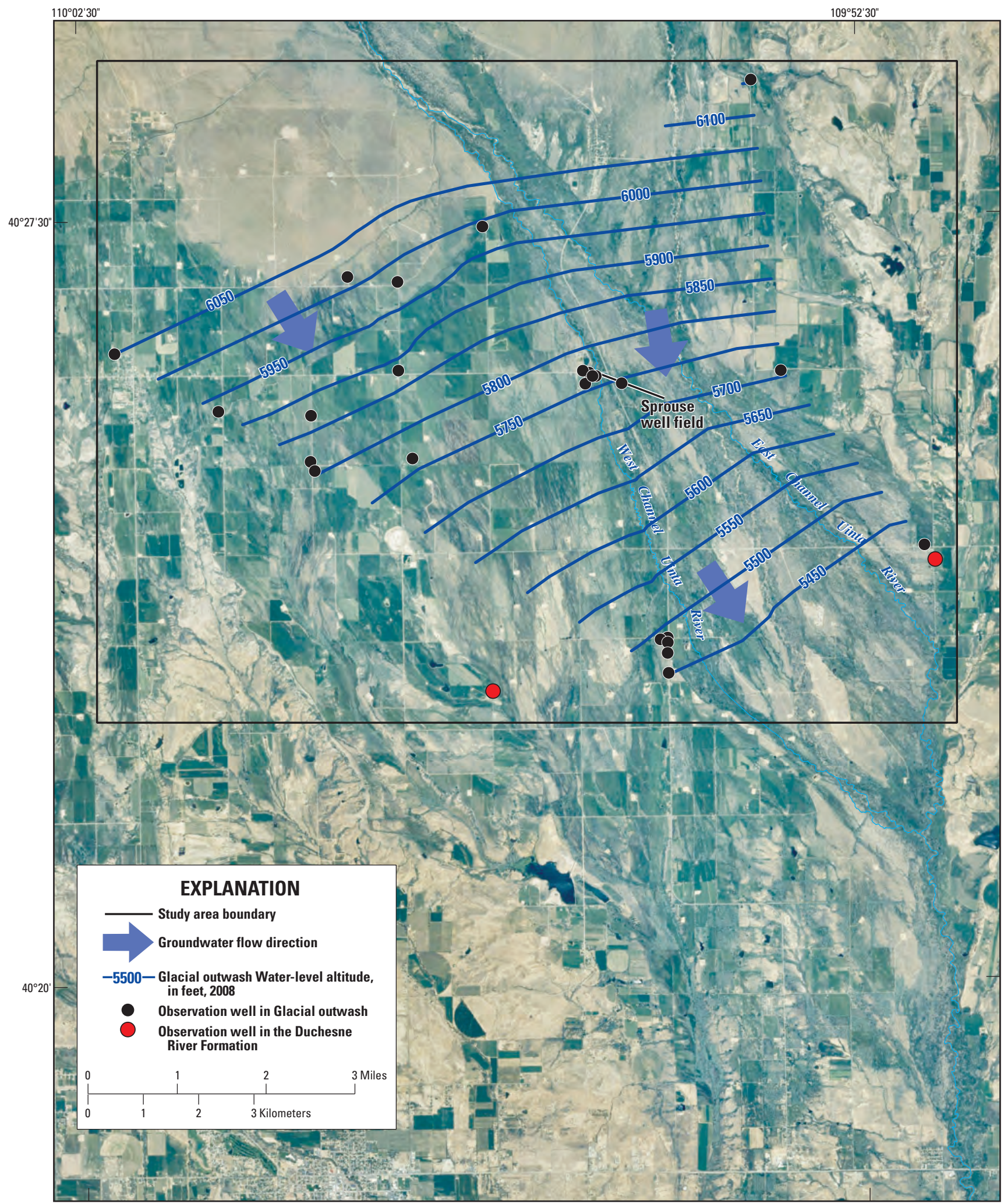

Base from U.S. Census Bureau cartographic boundary files, 2000

Imagery from U.S. Department of Agriculture Imagery, 2009

Universal Transverse Mercator Projection, Zone 12,

North American Datum of 1983

Figure 5. Altitude of the water-table in the glacial outwash aquifer in the study area, August 2008, and general direction of groundwater flow, Roosevelt Valley, Utah. 

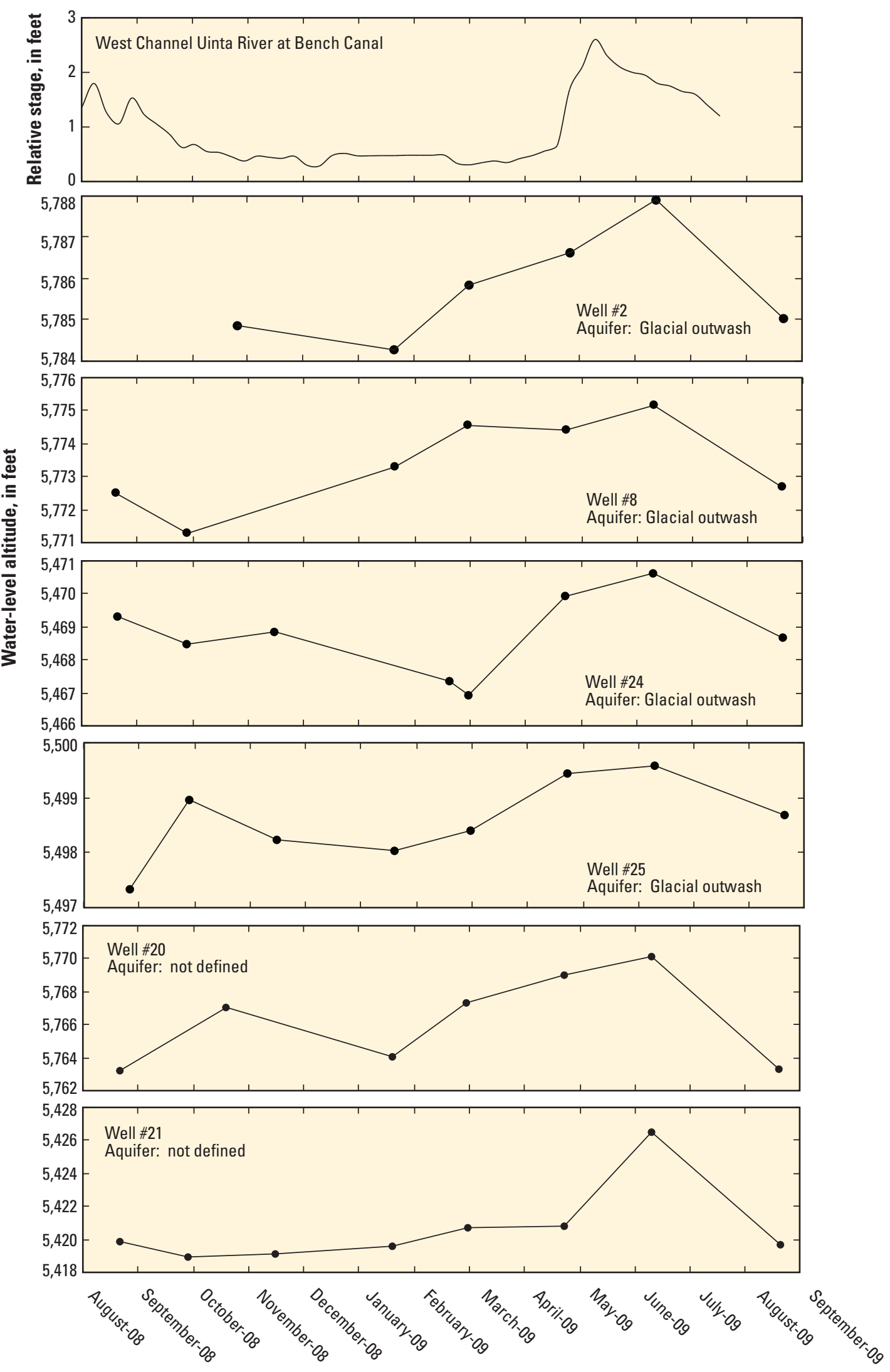

Figure 6. Water-level fluctuations in selected wells completed in glacial outwash in the study area and weekly moving average stage in the West Channel of the Uinta River near the Bench Canal, Roosevelt Valley, Utah. 


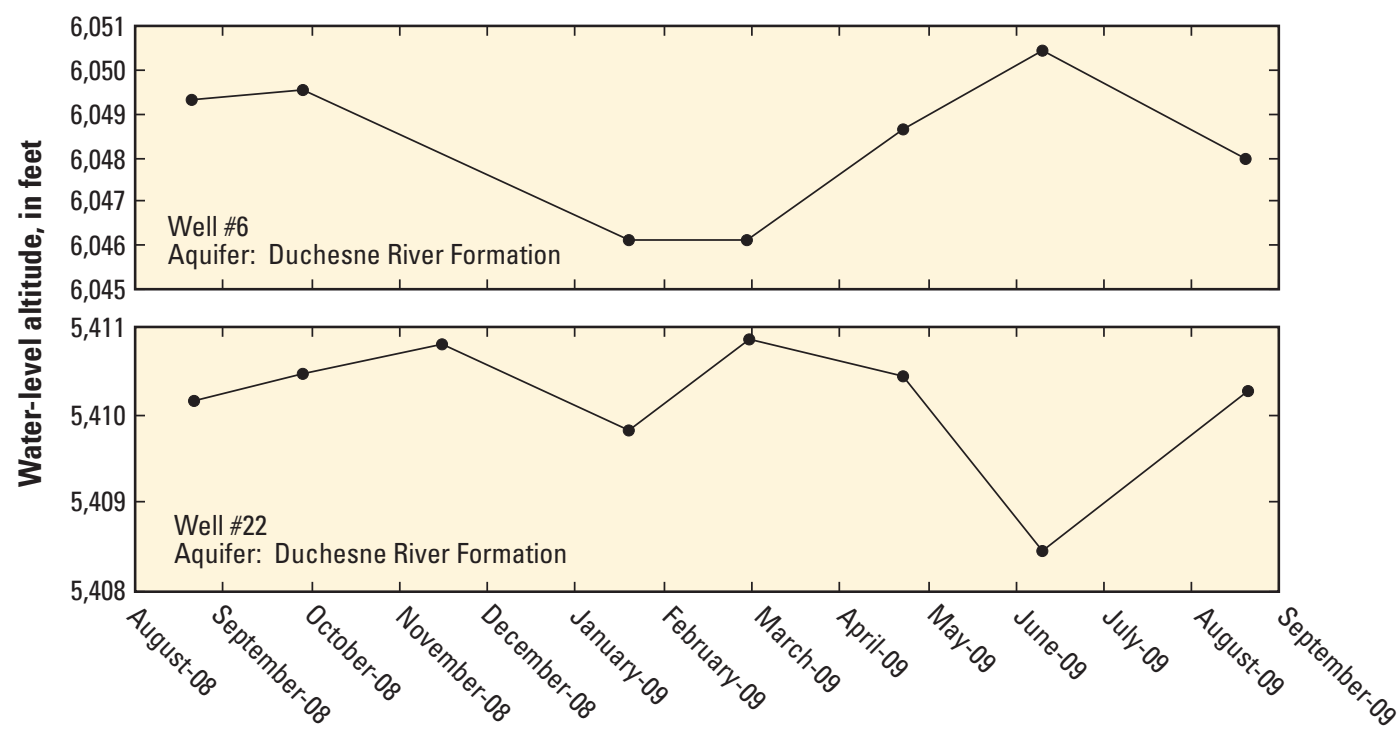

Figure 6. Water-level fluctuations in selected wells completed in glacial outwash in the study area and weekly moving average stage in the West Channel of the Uinta River near the Bench Canal, Roosevelt Valley, Utah._-Continued

Initially, measurements at the six observation wells were converted to water-level changes that were attributed solely to pumping at the Sprouse well. This calculation was done by subtracting the water level when pumping began (initial level) from water levels measured during the aquifer test, and adding the general water-level trend for the area. The initial water levels were estimated from measurements made at the observation wells within a 3-hour period prior to the start of pumping. The general water-level trend was established from continuous water-level records for MW 1 for the period September 24 to October 29, 2008. Water levels during that time were trending upward at a linear rate of $0.0243 \mathrm{ft} / \mathrm{d}$. On the basis of the barometric efficiency measured at the North well, it was assumed that the water-level data did not need to be corrected for barometric pressure fluctuations that occurred during the aquifer test.

Barometric efficiency and lithology indicate that groundwater in the outwash is unconfined; however, earlytime water-level drawdowns show a response consistent with water derived from decompression of water and aquifer material (well MW 1, fig. 7). In consideration of these factors, the aquifer-response solution described by Neuman (1972, 1975) was chosen for analysis of aquifer-test results. In the Neuman solution, a horizontally homogeneous unconfined aquifer of constant thickness with no-flow boundaries at the top and bottom is assumed (Fitts, 2002, p. 222). The constantthickness assumption is not met and was accounted for by adjusting measured water levels as described by Jacob (1963, p. 247). The solution was also adjusted for a variable pumping rate and wells that are not screened across the entire thickness of the aquifer.

Aquifer parameters were estimated by reducing the differences between Neuman solution water levels and water levels measured during the 11-day pumping period and for 30 days after pumping stopped. Parameter estimation was automated by minimizing a weighted sum of squares of the residuals (RSS) objective function (Duffield, 2006). Latetime water-level data, defined as water levels measured at times greater than 1,000 minutes after start of pumping, were assigned more weight than early-time data. Quantifying the interaction between elastic storage and gravity drainage of the aquifer (early-time response) is not the primary purpose of the aquifer test; quantifying aquifer response to induced water-level declines underneath the West Channel (late-time response) is the primary objective. Parameter estimation was constrained by establishing a probable range for transmissivity $\left(500-3,000 \mathrm{ft}^{2} / \mathrm{d}\right.$ ) and specific yield (less than 0.15$)$. The constraints were determined by visual fitting of the Theis (1935) response solution to late-time drawdown data.

No single set of parameter values gives a reasonable match to the range of drawdown responses measured at the six observation wells. Measured water levels for times greater than 50 minutes are matched for all observation wells (fig. 7). Response within the first 10 minutes of pumping could not be matched for any of the wells. Slightly higher storage values were estimated for wells MW 2 and MW 3 to better match measured drawdown. In general, early-time water levels control the estimates of storage, whereas maximum drawdown and recovery data control the estimates of transmissivity. The Neuman aquifer-solution parameter values determined for each of the six observation wells are listed in table 3. Transmissivity values range from about 1,600 to $2,300 \mathrm{ft}^{2} / \mathrm{d}$ with an average value of $1,900 \mathrm{ft}^{2} / \mathrm{d}$. If saturated thickness is assumed to be $150 \mathrm{ft}$, horizontal hydraulic conductivity is estimated to be $13 \mathrm{ft} / \mathrm{d}$. Specific yield of the outwash is estimated to be 0.06 . 
Table 2. Construction information for the Sprouse well and six observation wells used during the aquifer test, October and November 2008, Roosevelt Valley, Utah.

\begin{tabular}{lccccc} 
[-, no data] & \multicolumn{1}{c}{$\begin{array}{c}\text { Well } \\
\text { Well name }\end{array}$} & $\begin{array}{c}\text { Casing diameter } \\
\text { (inches) } \\
\text { (feet) }\end{array}$ & $\begin{array}{c}\text { Depth to water } \\
\text { prior to pumping } \\
\text { (feet below land } \\
\text { surface) }\end{array}$ & $\begin{array}{c}\text { Perforated interval Bottom of surface } \\
\text { (feet below land } \\
\text { surface) }\end{array}$ & $\begin{array}{c}\text { seal (feet below } \\
\text { land surface) }\end{array}$ \\
\hline North well & 58 & 6 & 11.49 & Open end & None \\
MW 1 & 60 & 8 & 8.61 & $40-60$ & 40 \\
MW 2 & 60 & 8 & 6.08 & $40-60$ & 40 \\
MW 3 & 60 & 8 & 6.59 & $40-60$ & 40 \\
Durigan well & 150 & 24 & 10.33 & $100-150$ & 14 \\
Red well & - & - & 7.98 & - & - \\
Sprouse well & 161 & 14 & - & $120-160$ & 20
\end{tabular}

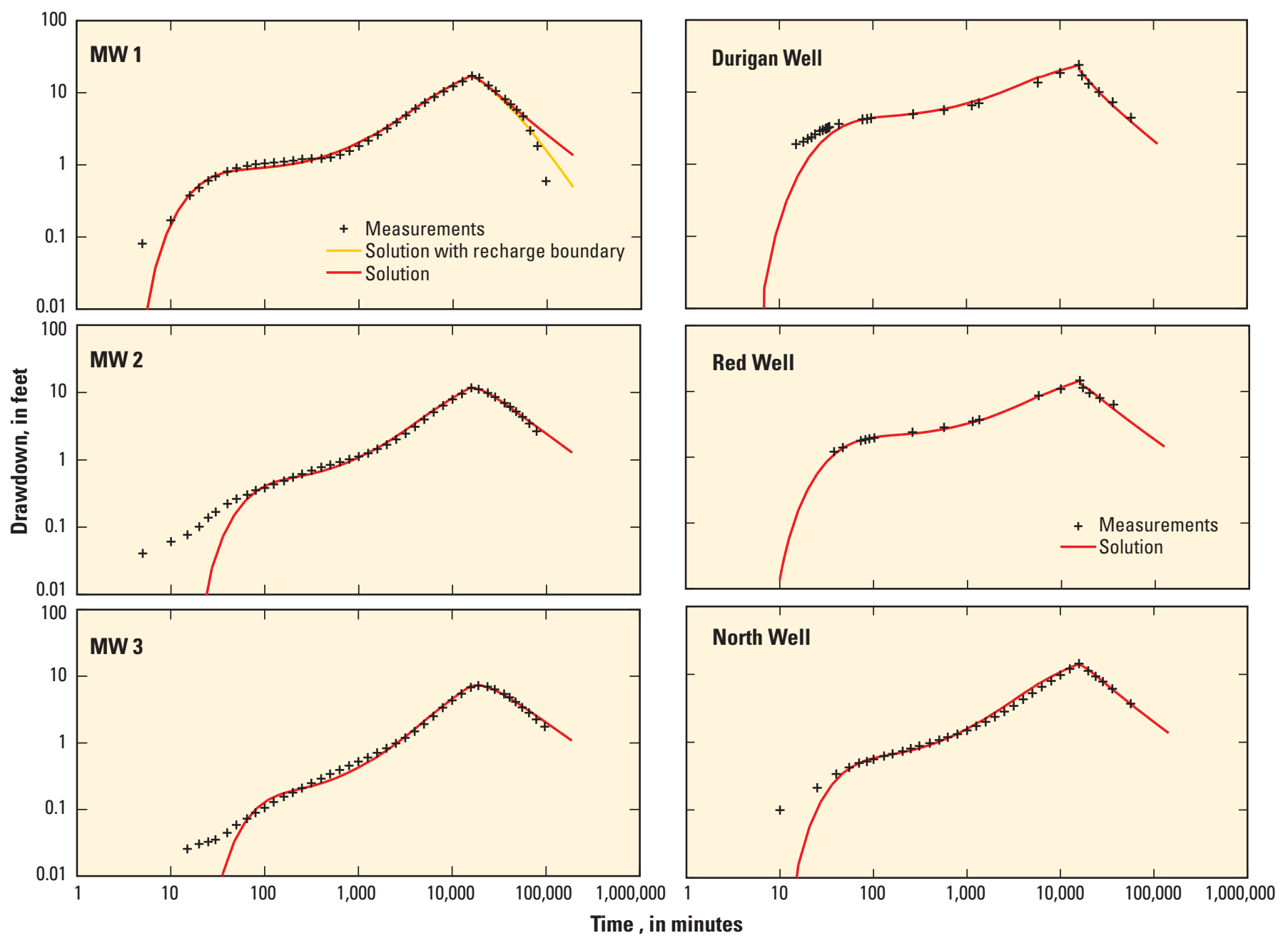

Figure 7. Measured water levels at six observation wells resulting from pumping at the Sprouse well and water levels determined from the Neuman aquifer-response solution, October and November 2008, Roosevelt Valley, Utah. 
Table 3. Observation-well characteristics and results of the Neuman aquifer-response solution to the Sprouse well aquifer test, October and November 2008, Roosevelt Valley, Utah.

\begin{tabular}{lcccccc}
\hline Well name & $\begin{array}{c}\text { Radial distance } \\
\text { from Sprouse well } \\
\text { (feet) }\end{array}$ & $\begin{array}{c}\text { Maximum } \\
\text { drawdown during } \\
\text { pumping (feet) }\end{array}$ & $\begin{array}{c}\text { Transmissivity } \\
\text { (square feet per } \\
\text { day) }\end{array}$ & $\begin{array}{c}\text { Storage } \\
\text { coefficient } \\
\text { (unitless) }\end{array}$ & $\begin{array}{c}\text { Specific } \\
\text { yield } \\
\text { (unitless) }\end{array}$ & $\begin{array}{c}\text { Ratio of vertical to } \\
\text { horizontal hydraulic- } \\
\text { conductivity (unitless) }\end{array}$ \\
\hline MW 1 & 390 & 19.69 & 1,570 & 0.0008 & 0.11 & 0.59 \\
Durigan well & 489 & 26.09 & 2,000 & 0.0008 & 0.03 & 0.19 \\
North well & 618 & 15.56 & 1,990 & 0.0009 & 0.05 & 0.28 \\
MW 2 & 644 & 12.33 & 1,630 & 0.0012 & 0.06 & 0.28 \\
Red well & 760 & 15.39 & 2,260 & 0.0005 & 0.03 & 0.12 \\
MW 3 & 840 & 7.44 & 1,920 & 0.0012 & 0.06 & 0.25 \\
\hline
\end{tabular}

Measured water-level drawdown at all observation wells showed no indication that a source of recharge was intercepted, nor that the glacial outwash aquifer was trending toward equilibrium conditions. This result means that the areal extent of water-level decline likely did not reach the West Channel of the Uinta River during the pumping period. If the West Channel had been a substantial source of water during the aquifer test, the rate of drawdown would have decreased noticeably. There was also no clear indication that groundwater gradients at the West Channel, as determined from measurements at stream piezometers (fig. 2, pz-3, pz-4, and pz-5), were affected during pumping.

Only at well MW 1 during water-level recovery (17 days after the end of pumping) was there a noticeable indication that some type of recharge source was intercepted. Once pumping stopped and in spite of water-level rises at observation wells, the spatial extent of water-level decline would have continued to expand until enough recharge was intercepted to replenish groundwater released from aquifer storage during pumping. The fact that recharge is seen only in the response at well MW 1 indicates that the source may be related to aquifer heterogeneity or to the pond (fig. 2) rather than a more broad-scale interaction between the glacial outwash and West Channel of the Uinta River.

To examine the conditions measured at MW 1, a constanthead boundary matching the location of the West Channel of the Uinta River was imposed on the Neuman aquifer-response solution. In contrast to the aquifer heterogeneity implication of the previous paragraph, the West Channel geometry was used because it addresses the primary objective of the aquifer test (assessing groundwater/surface-water interaction). The boundary was implemented through superposition and imaging (Duffield, 2006). Applying the boundary has minimal effect on the response solution for drawdown at MW 1 (fig. 7), but does improve the recovery match to measured water levels. For the other observation wells, the match to measured recovery is inferior when the recharge boundary is imposed. This contradiction further supports the concept that hydraulic interaction with the West Channel did not occur within the area defined by the observation wells and on the time scale of the aquifer test.

\section{Fluxes between Groundwater and Surface Water}

Groundwater moves along flow paths of varying length from areas of recharge to areas of discharge. The West and East Channels of the Uinta River can be both a source of recharge to groundwater, as streamflow seeps through the streambed to the water table, and a discharge boundary where groundwater discharges into the river through the streambed. Whether a reach of the Uinta River is losing water to groundwater or gaining flow from groundwater is dependent on the relation of stream stage to the water level in the underlying aquifer. For groundwater to discharge into a stream channel (gaining stream), the altitude of the water table in the vicinity of the stream must be higher than the elevation of the stream-water surface (fig. 8a). For surface water to recharge groundwater (losing stream), the altitude of the water table in the vicinity of the stream must be lower than the elevation of the stream-water surface (fig. 8b). The vertical flow direction can vary along a given stream reach. Also, vertical flow direction in one location in the reach can change over time as a result of temporal changes in the elevation of the stream-water surface and (or) the water table.

Stream/aquifer interactions, including streamflow losses and gains, and changes in those interactions over time were assessed on a section of the West Channel of the Uinta River using three methods: (1) synoptic measurement of discharge in the stream at multiple sites using tracer-injection and dilution methods, (2) periodic measurement of vertical hydraulic gradient across the streambed at eight sites, and (3) continuous measurement of streambed and stream-water temperature at seven sites. The first method allowed for quantification of stream-reach gain or loss within selected stream reaches at a discrete time. Methods (2) and (3) allowed for continuous assessment of the direction of flux across the streambed at selected points to determine whether the distribution of gaining and losing reaches was changing over time. 
$\boldsymbol{A}$

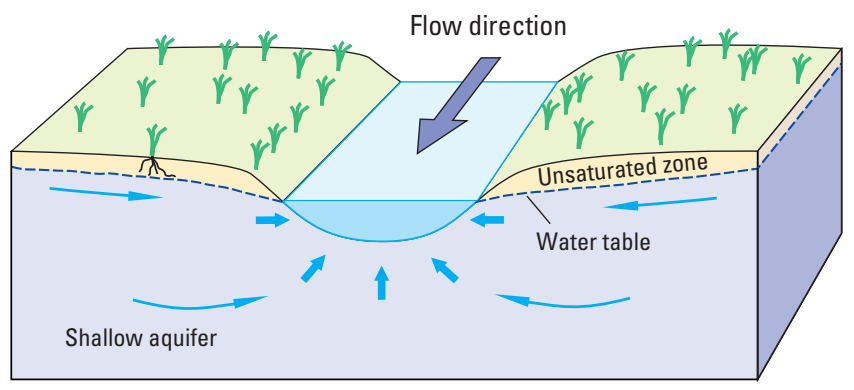

B

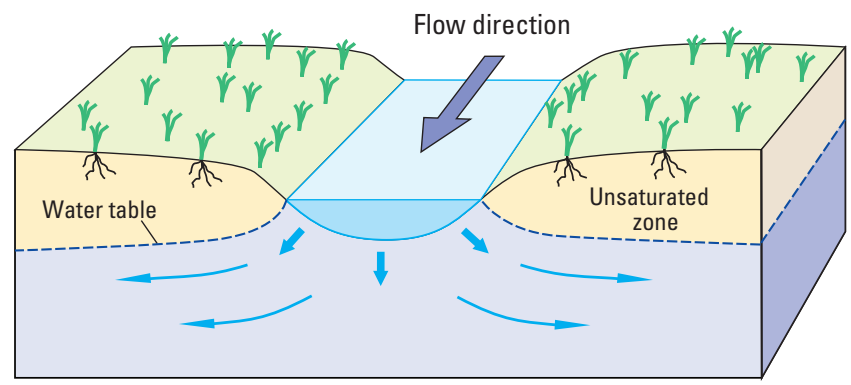

From Winter and others, 1998

Figure 8. Interaction of groundwater and surface water in $A$, a gaining stream and $B$, a losing stream.

\section{Tracer-Injection and Dilution Discharge Measurements}

Seepage studies provide the means to measure the gain or loss of streamflow that results from fluxes between groundwater and surface water (Winter and others, 1998), yet quantifying discharge in cobble-bottomed streams, such as the reaches of the Uinta River within the study area, presents challenges to traditional area-velocity measurement approaches. The traditional area-velocity method of measuring discharge (Rantz and others, 1982) is compromised in such streams because of the roughness of the cobbled bottoms and the variability of pools and riffles (Jarrett, 1992). An even greater obstacle is that a portion of the water in mountain streams flows among the cobbles in the hyporheic zone ${ }^{1}$ (Bencala and others, 1990; Harvey and Bencala, 1993; Harvey and others, 1996). Therefore, a direct measurement of discharge in the stream channel may miss a substantial percentage of the streamflow, resulting in an underestimate of the total flow (Zellweger and others, 1989; Kimball, 1997).

Determination of discharge through tracer-dilution (tracerinjection and dilution) methods includes hyporheic-zone flow and can provide needed precision when the goal of a seepage run is to quantify inflows to the stream that may be only a few percent of the total streamflow. Continuous and instantaneous (slug) tracer-dilution methods were applied and combined during this study to enable the quantification of gain and loss in the West Channel of the Uinta River as described in the following sections.

\section{Slug Tracer-Injection Method}

An instantaneous injection (slug) of a known mass of tracer salt can be used to determine discharge (Kilpatrick and Cobb, 1985). This slug injection is independent of the continuous tracer injection (discussed in the next section). Once the tracer salt is well mixed with the stream water, the method relies on the measurement of the tracer concentration as it passes a point downstream (fig. 9a). Sodium bromide $(\mathrm{NaBr})$ was used as the tracer for the instantaneous injections

\footnotetext{
${ }^{1}$ The hyporheic zone is the saturated interstitial zone beneath the streambed surface, and into the stream banks, that contains some portion of streamchannel water, or that has been altered by mixing of groundwater and surface water (Harvey and Bencala, 1993).
}

because the Br concentration can be measured using an ion-sensitive electrode positioned in the stream channel, and frequent readings can be stored in a data logger, providing a detailed profile of concentration as a function of time at a point (fig. 10). Br concentration was calculated from an equation expressing $\mathrm{Br}$ concentration as a function of millivolts, and the millivolts were recorded every 5 seconds by the data logger. The area under the curve (in milligram-seconds per liter) is determined by integrating the concentration profile. This area is divided into the mass of $\mathrm{Br}$ used (in milligrams) to obtain a value of discharge:

$$
Q_{2}=\left(M_{i n j} / A_{i n j}\right) /(28.3)
$$

where:

$$
\begin{gathered}
Q_{2} \text { is the downstream discharge from slug } \\
\text { injection (fig. } 9 \mathrm{a} \text { ), in } \mathrm{ft}^{3} / \mathrm{s} \text {; } \\
M_{i n j} \text { is the mass of the } \mathrm{Br} \text { tracer, in } \mathrm{mg} \text {; } \\
A_{i n j} \text { is the area under the concentration-time } \\
\text { profile, in mg-s/L; and } \\
28.3 \text { is the conversion factor from } \mathrm{L} / \mathrm{s} \text { to } \mathrm{ft}^{3} / \mathrm{s} \text {. }
\end{gathered}
$$

Seepage over a given stream reach can be determined by repeating the slug injections, and calculating and comparing discharge at the points farthest up- and downstream on the selected reach or reaches. The result is an estimate of net gain or loss in the selected reach. Seepage over a given stream reach can be determined by repeating the slug injections, and calculating and comparing discharge at the up and downstream points of the selected reach or reaches. The result is an estimate of net gain or loss in the selected reach. The change in flow observed by the difference in discharge measured at the ends of the selected stream reach is considered a net gain or loss. Yet both gain and loss to streamflow may be occurring within the selected reach, but only net gain or loss can be defined from the slug injection discharge measurements.

\section{Continuous Tracer-Injection Method}

A continuous tracer injection is conducted with the assumption that stream water, both the surface and the hyporheic flow, can be well mixed with the tracer after an appropriate length of time. Once the stream and hyporheic zones are well mixed with the tracer (fig. 9b), dilution of the tracer at any downstream location will indicate an increase in discharge. Salts like $\mathrm{NaBr}$ and sodium chloride $(\mathrm{NaCl})$, which 


\section{A Slug injection}

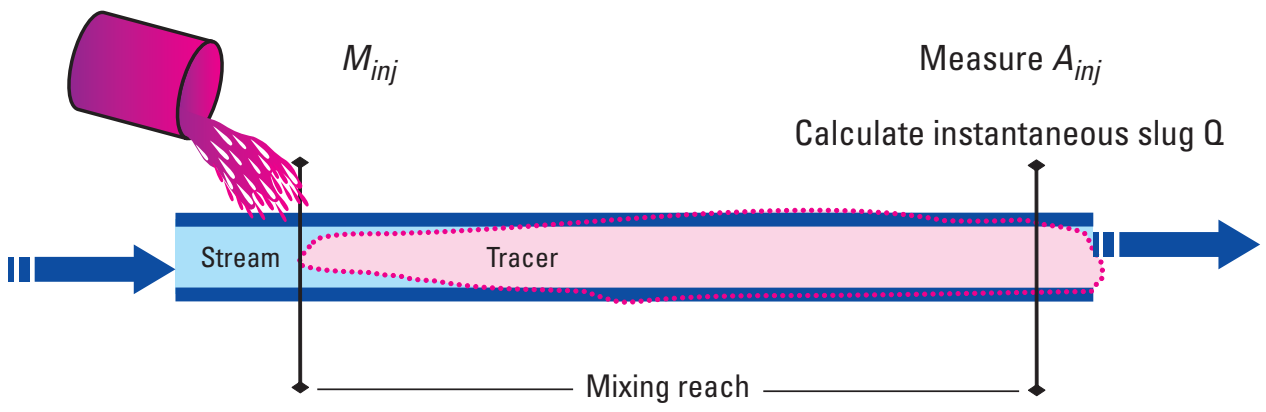

$B$ Continuous injection

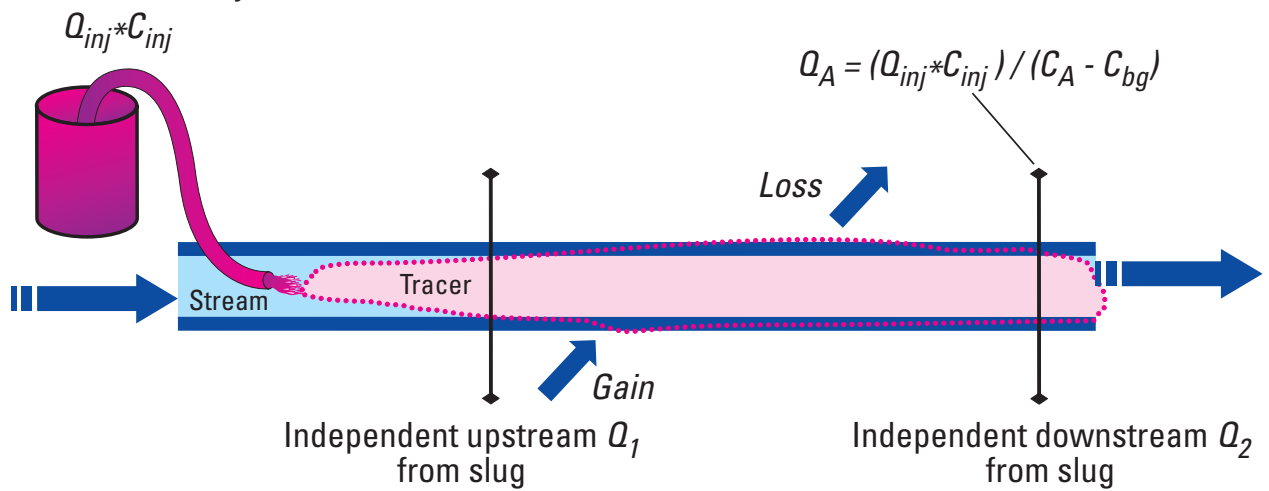

Figure 9. Approach to $A$, slug tracer-dilution discharge measurements and $B$, continuous tracer-injection discharge measurements, Roosevelt Valley, Utah.

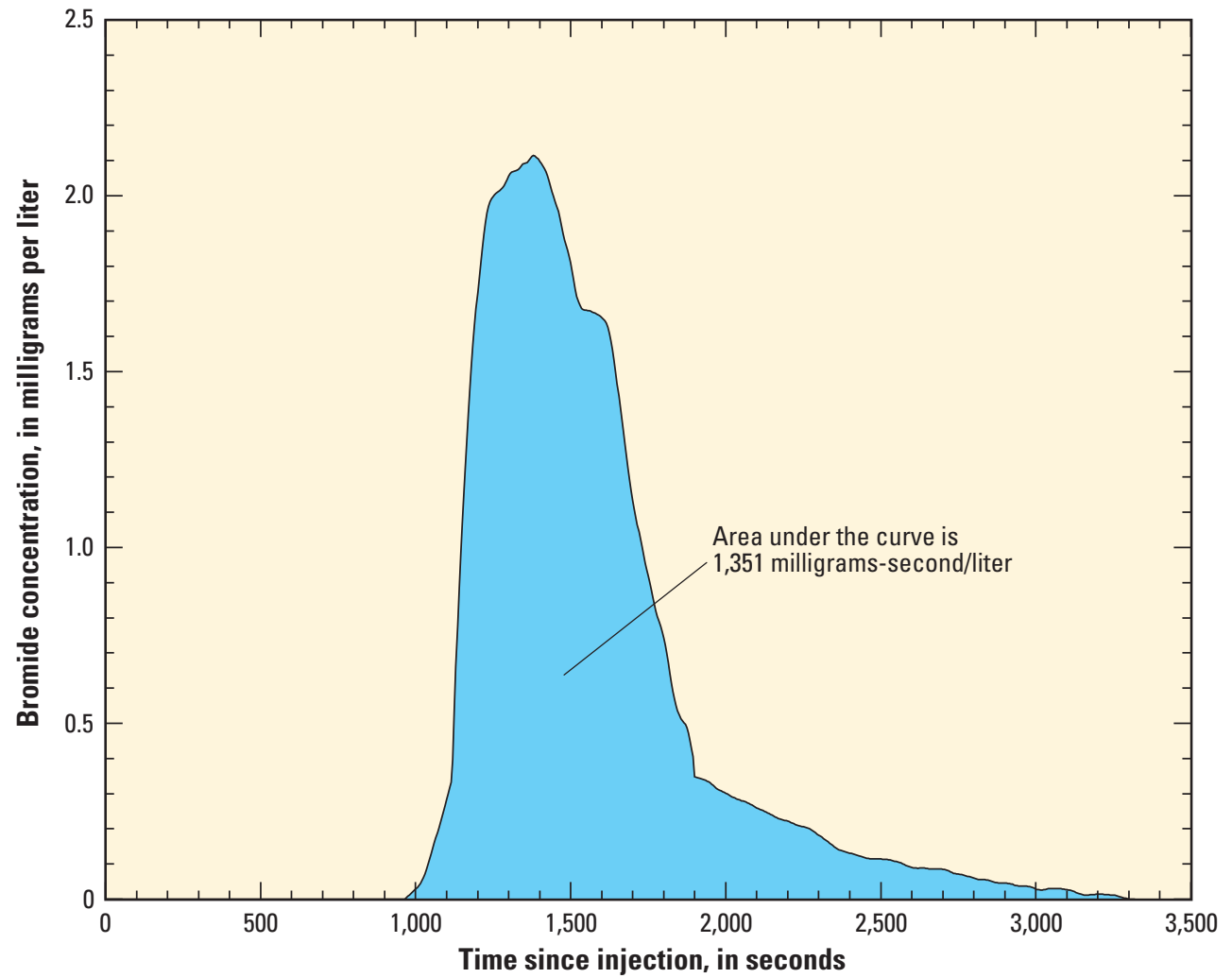

Figure 10. Variation in bromide concentration with time for slug injection at site 4A, West Channel of the Uinta River, Roosevelt Valley, Utah, November 2008. 
was used for the continuous injection in the Uinta River, are conservative tracers in that the $\mathrm{Br}$ or the $\mathrm{Cl}$ is not lost from the stream water through biological or chemical reactions. Natural background concentrations of $\mathrm{Br}$ and $\mathrm{Cl}$ in the Uinta River are low and consequently, inflows of water to the stream would contain equally low $\mathrm{Cl}$ concentrations. Given these conditions, discharge of the stream at any location downstream from the location of the tracer injection can be determined by:

$$
Q_{A}=\left(Q_{i n j}\right)\left(C_{i n j}\right) /\left(C_{A}-C_{b g}\right) /(28.3)
$$

where:

$$
\begin{aligned}
& Q_{A} \quad \text { is the downstream discharge from continuous } \\
& \text { injection, in } \mathrm{ft}^{3} / \mathrm{s} \text {; } \\
& Q_{i n j} \quad \text { is the continuous tracer injection rate, in } \mathrm{L} / \mathrm{s} \text {; } \\
& C_{i n j} \quad \text { is the injected tracer }(\mathrm{Cl}) \text { concentration, in } \\
& \mathrm{mg} / \mathrm{L} \text {; } \\
& C_{A} \text { is the tracer concentration at the downstream } \\
& \text { location, in } \mathrm{mg} / \mathrm{L} \text {; } \\
& C_{b g} \quad \text { is the natural background concentration, in } \\
& \mathrm{mg} / \mathrm{L} \text {; and }
\end{aligned}
$$

For the continuous tracer injection in the West Channel of the Uinta River, the injection rate was $0.003291 \mathrm{~L} / \mathrm{s}$, the injected $\mathrm{Cl}$ concentration was $164,390 \mathrm{mg} / \mathrm{L}$, and the natural background concentration was $0.04 \mathrm{mg} / \mathrm{L}$.

Although the result of the continuous-injection method for determining tracer-dilution discharge is a good indicator of streamflow gain, the method cannot be used independently to quantify loss. As water is lost from the stream, no difference in tracer concentration occurs in the remaining or departing water mass.

\section{Combination of Methods for Gain-Loss Study}

Both gain and loss within a selected reach can be determined by combining the continuous-injection and slug tracer-injection methods. Using the change in discharge calculated from the continuous injection $\left(Q_{A}\right.$; fig. $\left.9 \mathrm{~b}\right)$ and the independent measurement of discharge from instantaneous slug injections at two locations $\left(Q_{1}\right)$ and $\left(Q_{2}\right)$ (fig. $\left.9 \mathrm{~b}\right)$, the gain and loss are calculated as follows:

$$
\begin{aligned}
& Q_{\text {gain }}=\left(Q_{A}-Q_{1}\right) /(28.3) \\
& Q_{\text {loss }}=\left(Q_{A}-Q_{2}\right) /(28.3)
\end{aligned}
$$

where:

$$
\begin{aligned}
& Q_{\text {gain }} \quad \text { is the gain in discharge from location } 1 \text { to } \\
& \text { location } 2 \text {, in } \mathrm{ft}^{3} / \mathrm{s} \text {; } \\
& Q_{A} \quad \text { is the continuous-injection discharge } \\
& \text { measured at location 2, in } \mathrm{ft}^{3} / \mathrm{s} \text {; } \\
& Q_{1} \quad \text { is an instantaneous discharge measurement at } \\
& \text { location } 1 \text {, in } \mathrm{ft}^{3} / \mathrm{s} \text {; } \\
& Q_{\text {loss }} \quad \text { is the loss in discharge from location } 1 \text { to } \\
& \text { location } 2 \text {, in } \mathrm{ft}^{3} / \mathrm{s} \text {; } \\
& Q_{2} \quad \text { is an instantaneous discharge measurement at } \\
& \text { location 2, in } \mathrm{ft}^{3} / \mathrm{s} \text {; and }
\end{aligned}
$$

\section{Results of Tracer-Dilution Discharge Measurements}

In November 2008, instantaneous slug injections were used to quantify flow at the upstream and downstream ends of four separate reaches in the study area (see figure 11 for locations). The boundaries of these reaches were chosen upstream and downstream from diversion ditches. Resulting discharge values calculated from the results of the November 2008 slug injections (table 4) indicate (1) a net loss in reach 1 (about 10 percent of streamflow) directly upstream from the Sprouse well field, (2) a net gain in reaches 2 and 3 (combined gain of about 10 percent of streamflow) directly south of and downstream from the Sprouse well field, and (3) a net loss in reach 4 (about 13 percent of streamflow) about 1 mi south of and downstream from the Sprouse well field.

In November 2009, instantaneous slug measurements were combined with a continuous tracer injection to estimate gain and loss in reaches 3 and 4 (fig. 11 and table 5) at the southern end of the study area. Measured vertical hydraulic gradient across the streambed and continuous measurement of streambed and stream temperature (discussed farther on in the report) at sites within and bracketing reaches 3 and 4 generally indicated gaining conditions in monitored sections in those reaches. The results of the November 2008 slug tracerinjection discharge measurements (table 4), however, indicated a net loss of flow along reach 4 . The November 2009 slug and continuous tracer injections (table 5) were done to provide a second estimate of net gain or loss along reaches 3 and 4, and to assess whether both losing and gaining subreaches might be present within those reaches.

Tracer-concentration profiles resulting from the continuous tracer injection are illustrated in figure 12. Assessment of the test results required accounting for changes in streamflow resulting from the upstream diversion of water during the test. The continuous $\mathrm{NaCl}$ injection started just after 10:00 a.m. on November 3, 2009 (fig. 12). Two samples were collected upstream from the injection site (site 2A) to determine the background $\mathrm{Cl}$ concentration. Two samples were collected at site $2 \mathrm{~B}$ downstream from the injection site to determine the increase in $\mathrm{Cl}$ concentration resulting from the injection. Analysis of samples collected with autosamplers at sites 3B and $4 \mathrm{~B}$ indicated the arrival of the $\mathrm{Cl}$ tracer downstream. Travel time from the injection site (site $2 \mathrm{~A}$ ) to site $3 \mathrm{~B}$ was 2 hours and 50 minutes, and travel time from site 2A to site 4B was 6 hours and 34 minutes. At both downstream sites, however, results of continued sampling indicated a sharp increase in $\mathrm{Cl}$ concentration. Stage data from a pressure transducer in the stream at site 3B clearly indicated a decrease in flow that corresponded to the increase in $\mathrm{Cl}$ concentration (fig. 12) as the injection continued at a constant rate upstream. Despite this unplanned change, the $\mathrm{Cl}$ concentrations at sites $2 \mathrm{~B}, 3 \mathrm{~B}$, and $4 \mathrm{~B}$ most likely reached plateau values before the effects of the water withdrawal reached each site. Samples that were used to represent plateau concentrations for the sites are shown in figure 12. These concentrations were input to equation 2 to obtain the discharge values reported in table 5 for the continuous injection. 


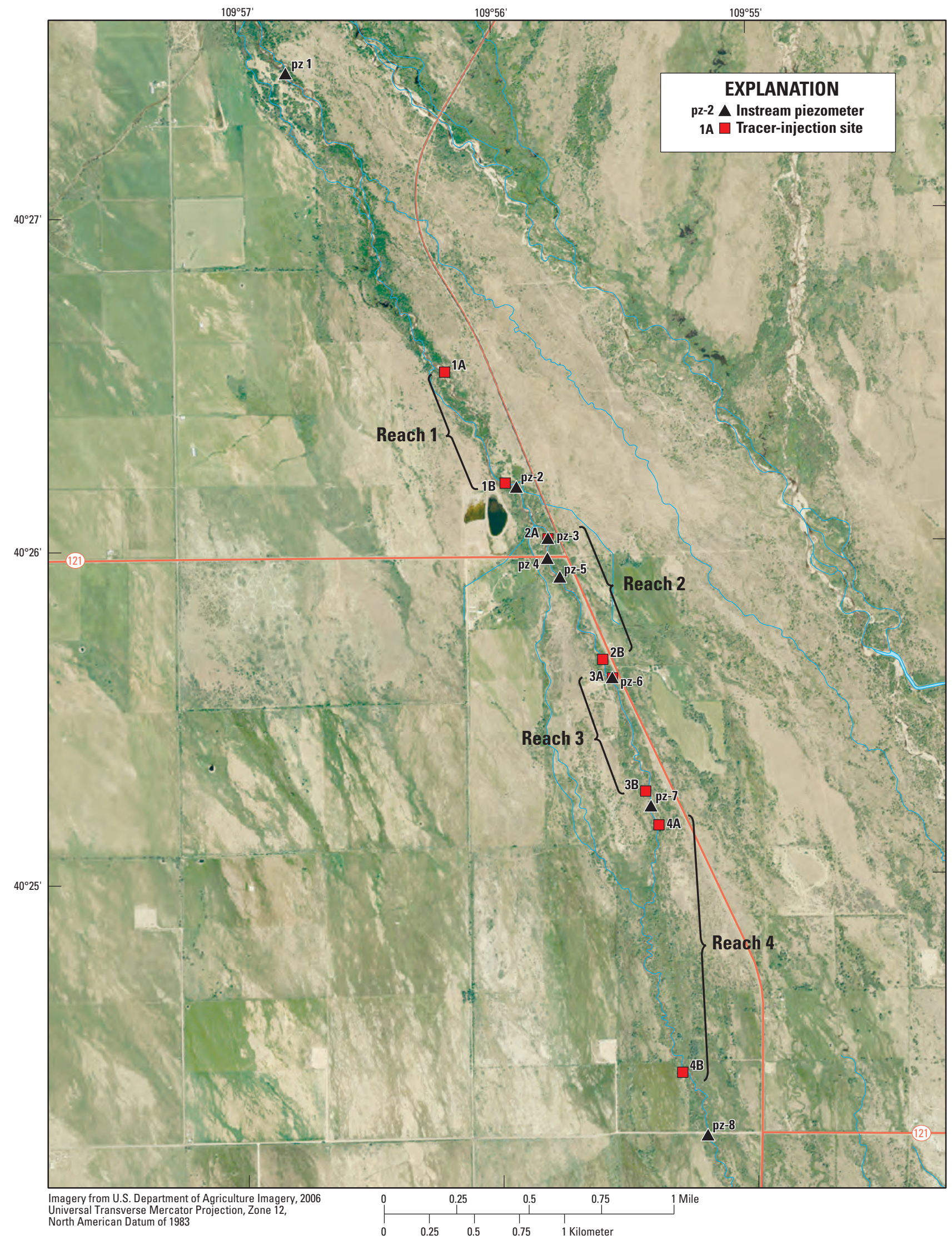

Figure 11. Location of tracer injection and dilution discharge measurement reaches, West Channel of the Uinta River, Roosevelt Valley, Utah. 
Table 4. Results of slug tracer-injection discharge measurements in selected reaches of the West Channel of the Uinta River, November 2008, Roosevelt Valley, Utah.

[Locations are shown in figure $11 ; \mathrm{ft}^{3} / \mathrm{s}$, cubic feet per second; - , no measurement or value]

\begin{tabular}{llcc}
\hline Reach and location & $\begin{array}{c}\text { Slug injection } \\
\text { discharge } \\
\left(\mathbf{f t}^{3} / \mathbf{s}\right)\end{array}$ & $\begin{array}{c}\text { Observed net gain } \\
\mathbf{o r ~ l o s s ~}(-)^{\left(\mathbf{f t}^{3} / \mathbf{s}\right)}\end{array}$ \\
\hline Reach 1 & Upstream at 1A & 10.2 & - \\
& Downstream at 1B & 9.2 & -1.0 \\
Reach 2 & Upstream at 2A & 10.5 & - \\
& Downstream at 2B & 11.1 & .6 \\
Reach 3 & Upstream at 3A & 8.7 & - \\
& Downstream at 3B & 9.2 & .5 \\
Reach 4 & Upstream at 4A & 7.6 & - \\
& Downstream at 4B & 6.6 & -1.0 \\
\hline
\end{tabular}

Resulting discharge values derived from November 2009 slug injections (table 5) indicate a net loss of about 13 percent of streamflow in reach 3 , whereas slug injection measurements made in November 2008 indicated a net gain. A slight net loss in streamflow (about 2 percent) was also measured in reach 4. Results of the November 2009 continuous tracer injection, however, showed an increase in flow from groundwater to the stream in both reaches, from 7.65 to $8.00 \mathrm{ft}^{3} / \mathrm{s}$ in reach 3 and from 6.63 to $7.44 \mathrm{ft}^{3} / \mathrm{s}$ in reach 4 , indicating a dynamic groundwater/surface-water interaction within stream reaches 3 and 4 , which contain both gaining and losing subreaches.

\section{Measurement of Vertical Hydraulic Gradient Across the Streambed}

To determine the direction of water movement across the West Channel of the Uinta River streambed at selected points within the study area and over time, the vertical hydraulic gradient across the streambed was measured periodically from August 2008 through April 2009 at eight instream piezometers (pz-1 to pz-8, fig. 11). High discharge in the river and resulting damage to the instrument installations during spring runoff precluded the measurement of vertical gradients after April 2009. Measurements at these sites were made in piezometers constructed of 1.5-in. diameter galvanized steel pipe, closed at the end with a $0.7-\mathrm{ft}$ perforated interval from 0.5 to $1.2 \mathrm{ft}$ from the bottom (fig. 13). Piezometers were hand-driven into the streambed. Penetration depths of the installed piezometers ranged from approximately 3.3 to $4.1 \mathrm{ft}$ below the streambed. Depths of the centers of the perforated interval ranged from 2.3 to $3.5 \mathrm{ft}$ below the streambed. The water level in the piezometer represents the water pressure in the streambed at the depth of the perforated interval. Both the stream water level and the water level in the piezometer (streambed water level) were measured during each site visit using a pressure manometer (fig. 13). Vertical gradient was computed by subtracting the stream water level from the piezometer water level and dividing the result by the vertical distance between the streambed and the center of the perforated interval (table 6). With this method, differences in stream and piezometer water levels of $0.01 \mathrm{ft}$ or greater could be discerned. No vertical gradient was reported when observed differences between stream and piezometer water levels were less than $0.01 \mathrm{ft}$.

Observed vertical gradients varied substantially during the study period at most instream piezometer sites, indicating possible changes in stream-stage/water-table relations, at least locally, at these sites over time. In general, however, downward gradients (negative gradient values, table 6), indicating the potential for water to seep from the stream to groundwater (losing stream), were measured at piezometers pz-1, pz-2, and pz-4, these piezometers were located approximately in the northern half of the study reach and upstream from the Sprouse well field (fig. 14). In contrast, upward gradients (positive gradient values, table 6), indicating the potential for water to move from groundwater to the stream (gaining stream), were generally observed at piezometers pz-5, pz-6, pz-7, and pz-8, these piezometers were located in the southern half of the study reach and downstream from the Sprouse well field (fig. 14). Relatively small vertical gradients, both downward and upward, were observed in piezometer pz-3, located just upstream from the Sprouse well field. These results generally agree with the results of the November 2008 slug tracer-injection discharge measurements (table 4) for reaches 1 to 3 (fig. 11). November 2008 slug tracer-injection discharge measurements indicated a net loss

Table 5. Results of combined slug and continuous tracer injections in selected reaches of the West Channel of the Uinta River, November 2009, Roosevelt Valley, Utah.

[Locations are shown in figure $11 ; \mathrm{ft}^{3} / \mathrm{s}$, cubic feet per second; - - no measurement or value]

\begin{tabular}{|c|c|c|c|c|c|c|}
\hline \multicolumn{2}{|c|}{ Reach and location } & \multirow{2}{*}{$\begin{array}{c}\text { Continuous injection } \\
\text { discharge } \\
\left(\mathrm{ft}^{3} / \mathrm{s}\right)\end{array}$} & \multirow{2}{*}{$\begin{array}{c}\text { Slug injection } \\
\text { discharge } \\
\left(\mathrm{ft}^{3} / \mathrm{s}\right)\end{array}$} & \multirow{2}{*}{$\begin{array}{c}\text { Gross gain } \\
\left(\mathbf{Q}_{\text {gain }}\right) \text { from } \\
\text { continuous tracer } \\
\left(\mathrm{ft}^{3} / \mathrm{s}\right)\end{array}$} & $\begin{array}{c}\text { Gross loss }(-) \\
\left(0_{\text {loss }}\right) \text { from combination } \\
\text { of slug and } \\
\text { continuous tracer } \\
\left(\mathrm{ft}^{3} / \mathrm{s}\right)\end{array}$ & $\begin{array}{c}\text { Net gain or loss }(-) \\
\text { from slug } \\
\text { injection tracer } \\
\left(\mathrm{ft}^{3} / \mathrm{s}\right)\end{array}$ \\
\hline Reach 3 & Upstream at 3A & & & & - & - \\
\hline & Downstream at 3B & 8.00 & 6.63 & 0.35 & -1.37 & -1.02 \\
\hline \multirow[t]{2}{*}{ Reach 4} & ${ }^{1}$ Upstream at 4A & 6.63 & 6.63 & - & - & - \\
\hline & Downstream at $4 \mathrm{~B}$ & 7.44 & 6.46 & 0.81 & -0.98 & -0.17 \\
\hline
\end{tabular}

\footnotetext{
${ }^{1}$ Upstream location for reach 4 was also the downstream location for reach 3 in the November 2009 injection.
} 


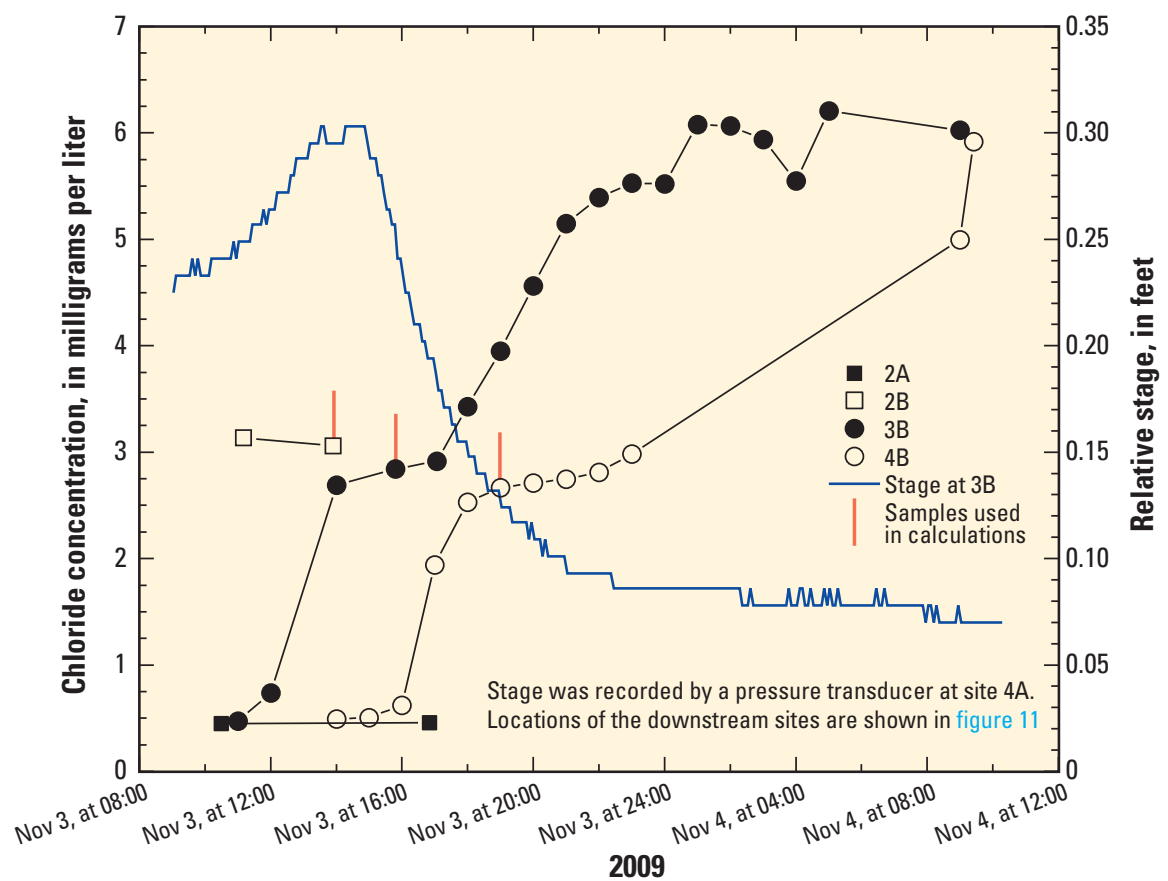

Figure 12. Variation in chloride concentration and relative river stage with time, West Channel of the Uinta River, Utah, November 2009.

Table 6. Vertical hydraulic gradients measured at piezometers in the West Channel of the Uinta River, Roosevelt Valley, Utah. [* indicates no discernable head difference and vertical gradient]

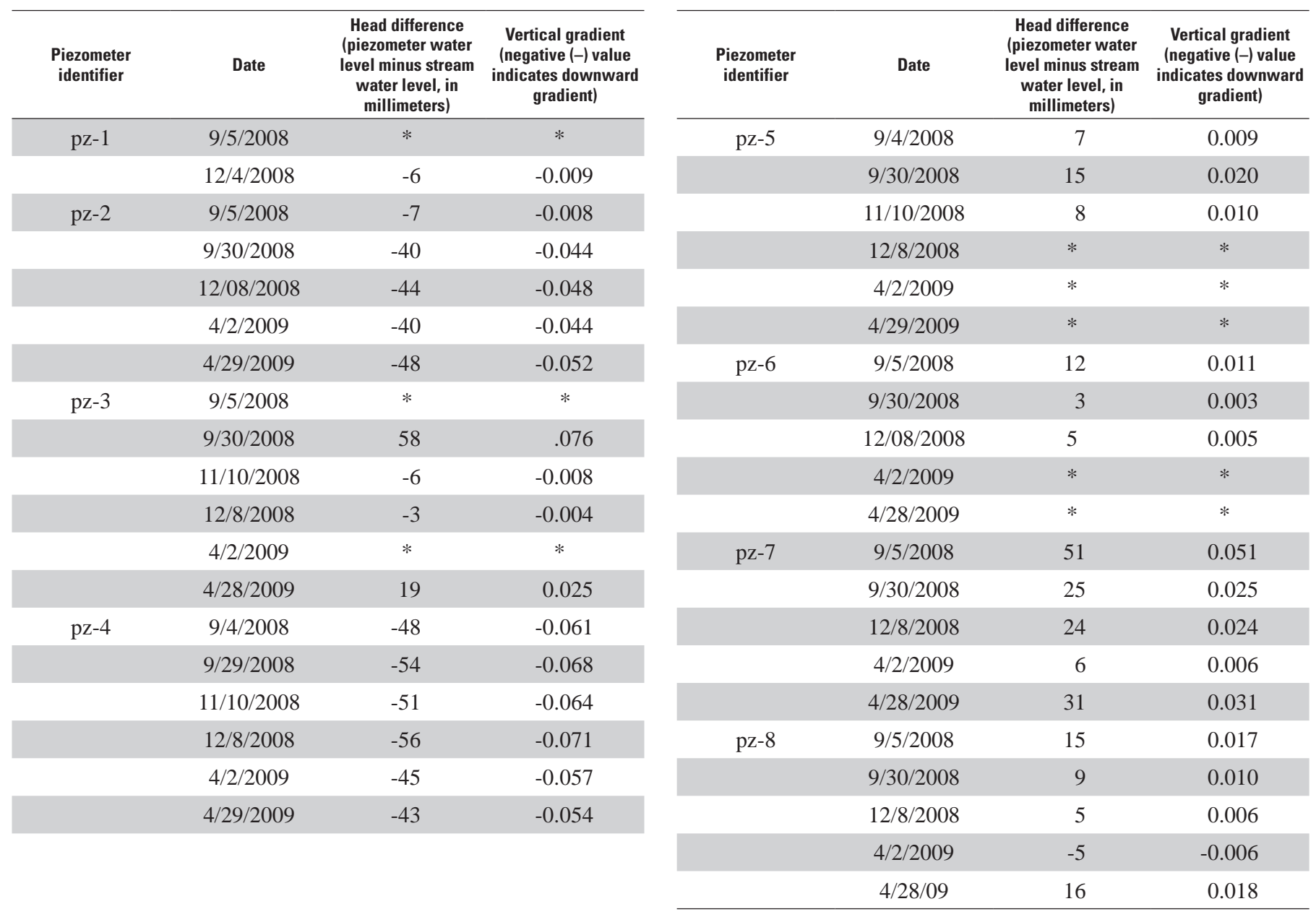


for reach 4 (fig. 11 and table 4), whereas vertical gradients at piezometer pz-7, located just north of the upstream end of the tracer-injection reach 4 , and piezometer pz-8, located about $0.2 \mathrm{mi}$ from the downstream end of that reach, generally indicated gaining stream conditions.

\section{Measurements of Stream and Streambed Water Temperature}

Naturally occurring changes in temperature in the nearstream environment are often substantial and provide a clear thermal signal that is easy to identify and use as a tracer of groundwater movement. Whenever there is a difference in temperature between two points along a groundwater flow path, heat will move between them by transport in the flowing water (advective heat flow) (Constantz and Stonestrom, 2003). Heat also moves by thermal conduction through nonmoving solids and fluids; however, this transport mechanism is generally much less significant than advection in a typical stream environment. Heat movement, and therefore water flow, can be traced by continuous monitoring of temperature patterns in the stream and streambed. Numerical heat-transport models have been used to interpret these data; however, even without synthesis of the data by using modeling tools, temperature patterns can immediately indicate the general character of the flow regime (Constantz and Stonestrom, 2003).
The theoretical thermal responses associated with gaining and losing stream conditions are illustrated in figure 15; it was assumed that both conditions could occur in the West Channel of the Uinta River within the study area. Reaches of the stream channel in which streambed temperature fluctuations are highly damped relative to instream fluctuations indicate movement of groundwater to the stream (gaining stream) (fig. 15a). In contrast, reaches of the stream channel where fluctuations in streambed temperatures closely follow instream

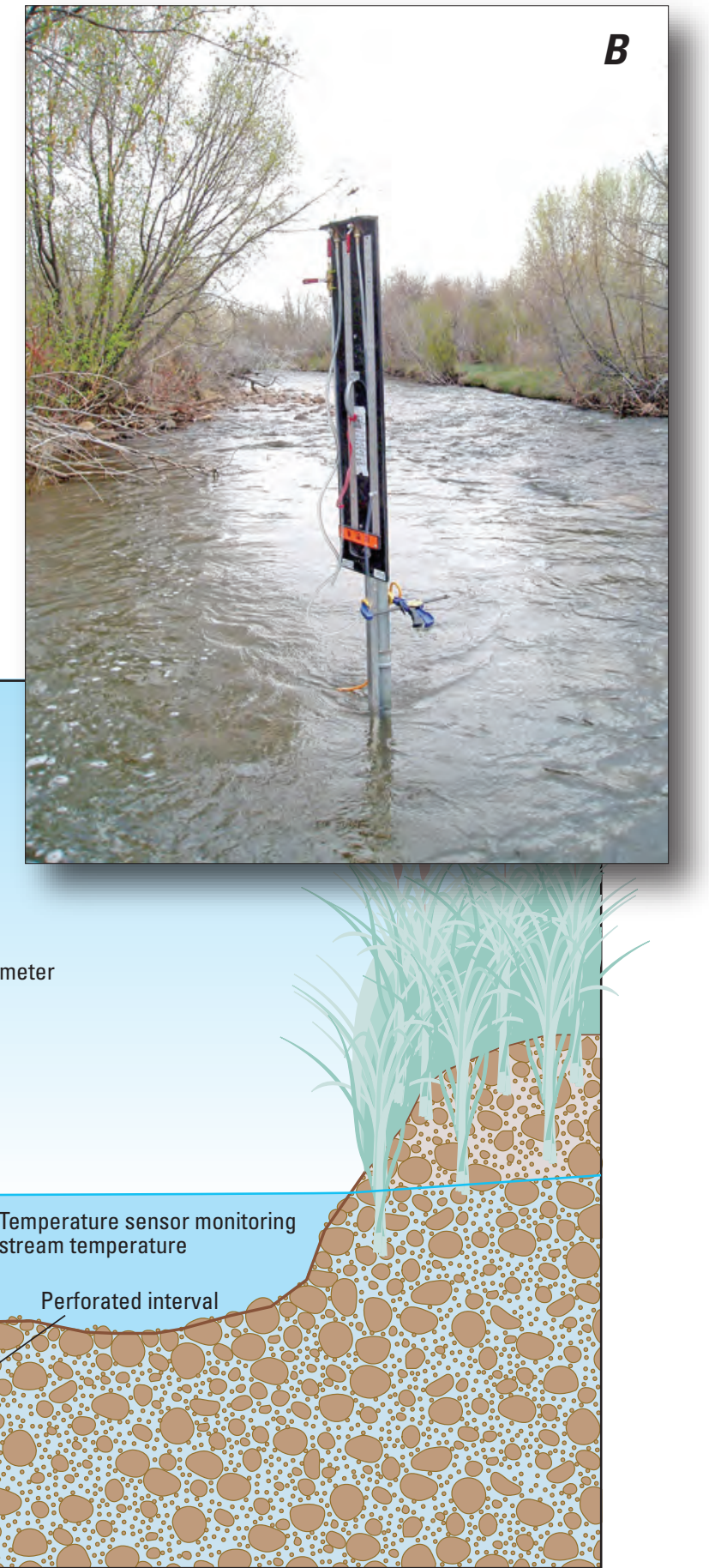

Figure 13. $A$, an installed instream piezometer with temperature sensor and $B$, photograph of pz-7 with manometer board attached, Roosevelt Valley, Utah. 


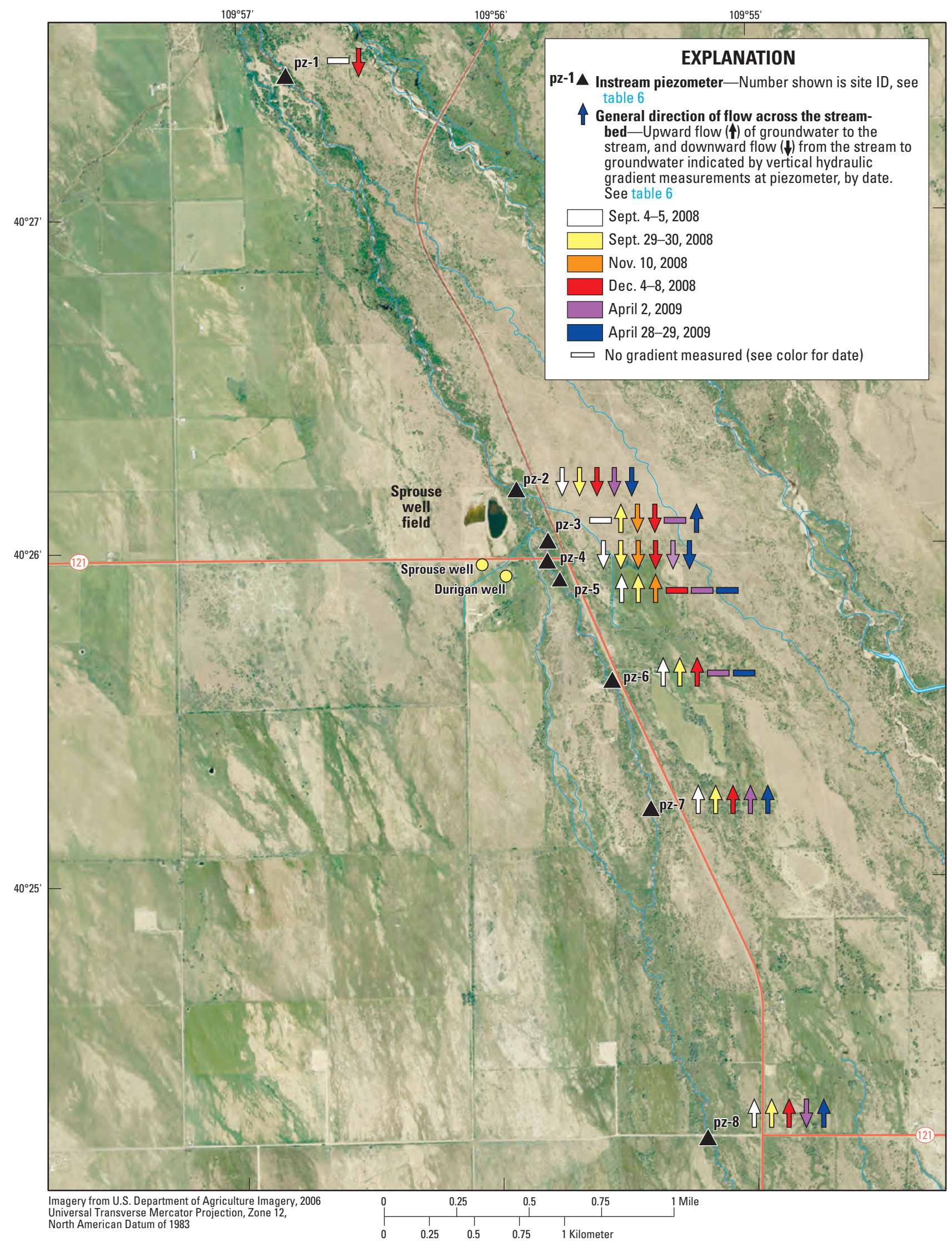

Figure 14. Direction of vertical hydraulic gradient measured at instream piezometers in the West Channel of the Uinta River, Roosevelt Valley, Utah. 

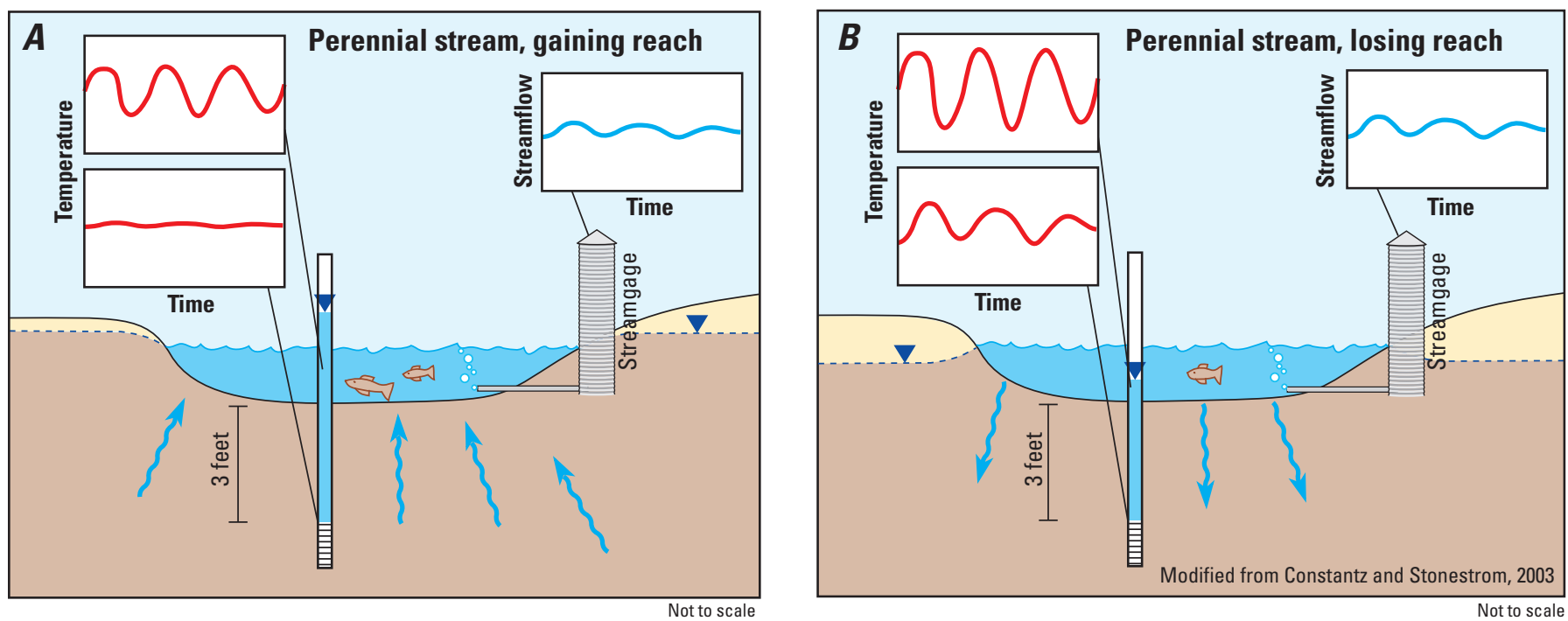

Figure 15. Thermal and hydraulic responses to two possible streambed conditions: $A$, perennial stream, gaining reach and $B$, perennial stream, losing reach.

temperature fluctuations indicate water loss through the streambed to groundwater (losing stream) (fig. 15b).

Temperature sensors were installed inside each piezometer (fig. 13) to measure water temperature in the streambed at two depths. A shallow and a deep temperature sensor were positioned approximately $1 \mathrm{ft}$ apart from each other, with the depth of shallow sensors ranging from 0.8 to $1.8 \mathrm{ft}$ below the streambed and the depth of deep sensors ranging from 1.8 to $2.8 \mathrm{ft}$ below the streambed. Because the streambed is always saturated and the steel piezometer readily conducts heat, the water in the piezometer is assumed to be in thermal equilibrium with the water in the streambed (Stonestrom and Blasch, 2003). Sensors also were attached to the outside of the piezometers to measure stream water temperature. Temperature was measured from September 2008 to April 2009 at seven piezometer sites (pz-2 to pz-8, fig. 11). High discharge in the West Channel of the Uinta River and resulting damage to the piezometer installations during spring runoff precluded the collection of temperature data after April 2009. No temperature measurements were made in piezometer pz-1 as a result of equipment malfunction and damage to the piezometer after installation.

Streambed temperature patterns at the piezometer sites (fig. 16) indicate the presence of both losing and gaining stream reaches within the study area. In general, the data indicate thermal responses typical of losing stream reaches at piezometer sites pz-2 and pz-3 (fig. 16), located north of and upstream from the Sprouse well field. At these sites, streambed temperatures closely followed daily and multi-day trends in stream water temperatures and reflected the observed diurnal fluctuation in stream water temperature. Also characteristic of the temperature patterns at pz-2 and pz-3 is the convergence of streambed temperature with stream temperature at near $0^{\circ} \mathrm{C}$ during the winter months. In contrast, temperature data from piezometers pz-4 through pz-8 (fig. 16), located in the southern half of the study area downstream from the Sprouse well field, generally indicate thermal responses typical of gaining stream reaches for most of the periods of record. At these sites, particularly from November 2008 through April 2009 , streambed temperature fluctuations were highly damped relative to instream temperature fluctuations, and deep and shallow streambed temperatures were substantially different at any given time. Streambed temperature at these sites also remained substantially higher than stream temperature during the winter months, indicating that some groundwater was discharging through the streambed to the stream.

The results of monitoring streambed temperature indicate a similar general distribution of flow across the West Channel streambed - generally losing stream conditions north of the Sprouse well field and gaining conditions south of the well field - as is indicated by the November 2008 tracer-dilution (table 4) and vertical-gradient measurements (table 6). A discrepancy exists, however, between vertical head gradient and temperature data collected at piezometer pz-4 directly east of the Sprouse well field (fig. 14). At pz-4, a downward hydraulic gradient between the stream and the streambed was measured during all six visits to the site. Streambed temperature patterns, however, indicate that groundwater likely was moving into the stream (gaining stream) for most of the period of record (fig. 16). The reason for the discrepancy is not known. Although pz-4 was installed within $5 \mathrm{ft}$ of a concrete bridge-support structure, it is not clear whether the structure and associated streambed disturbance affected water levels in the streambed or stream at the piezometer site.

Although streambed temperature data indicate generally losing stream conditions north of and upstream from the Sprouse well field and generally gaining stream conditions south of and downstream from the well field, they also 

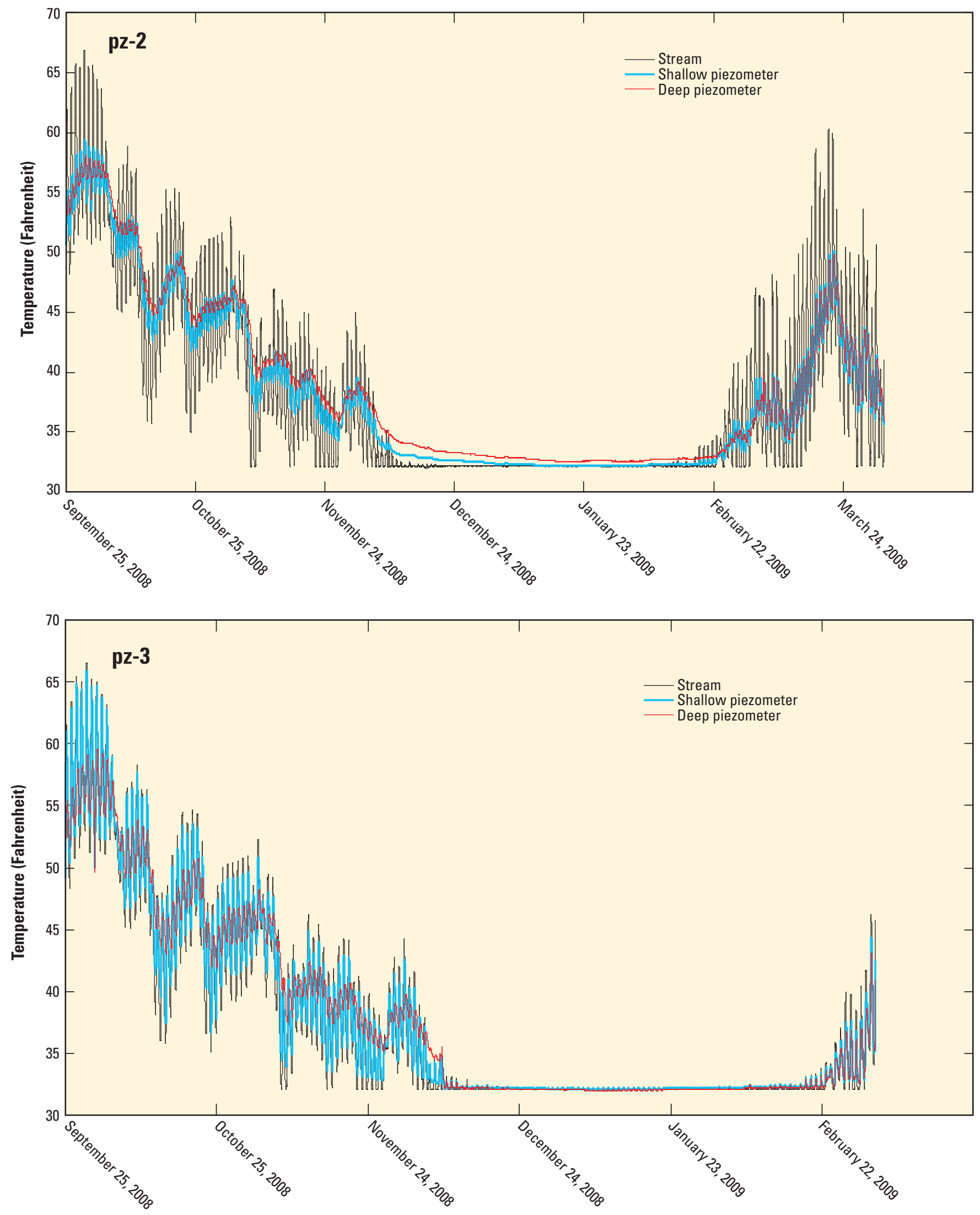

Figure 16. Water temperature in the West Channel of the Uinta River and instream piezometers, Roosevelt Valley, Utah. 

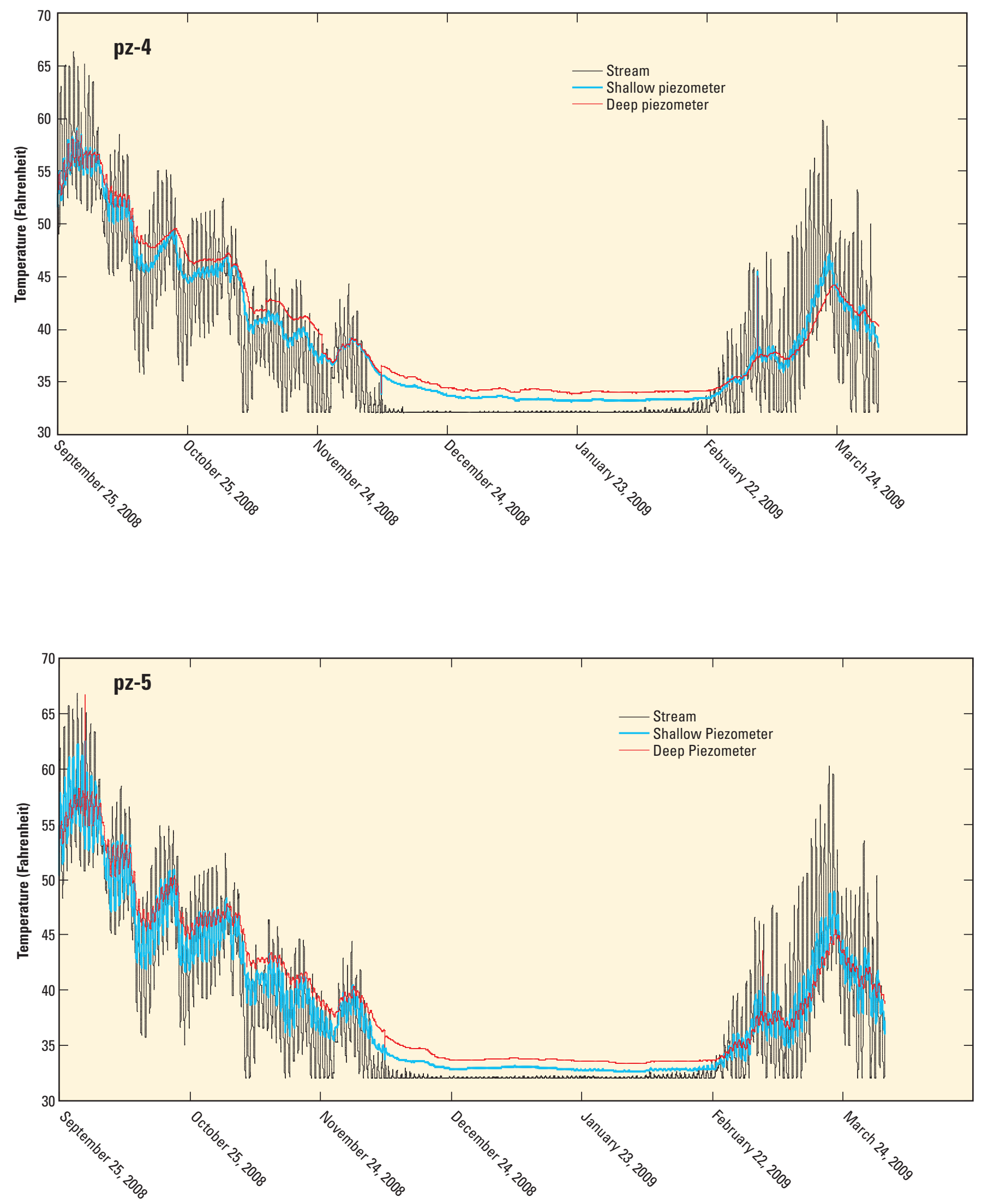

Figure 16. Water temperature in the West Channel of the Uinta River and instream piezometers, Roosevelt Valley, Utah.-Continued 

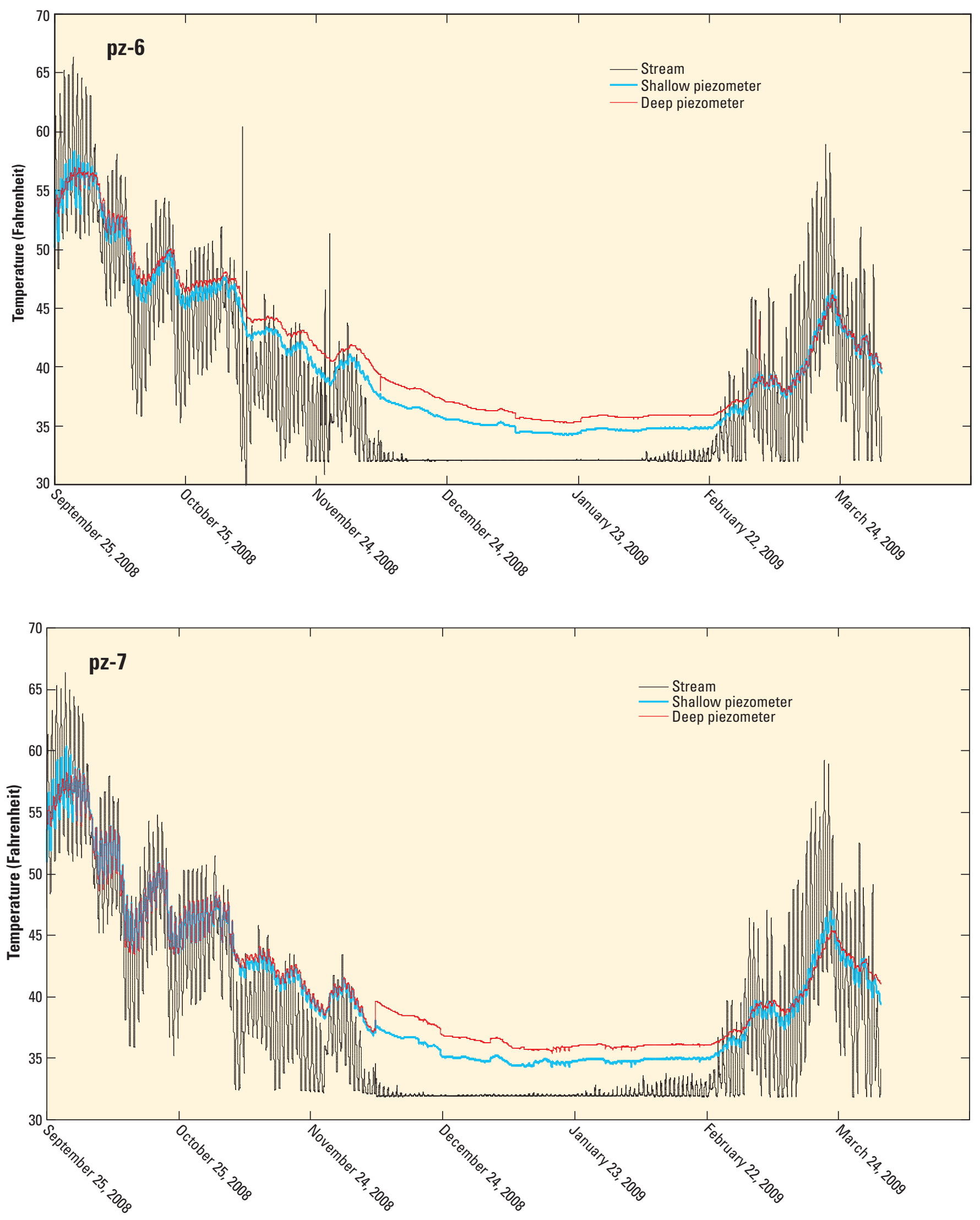

Figure 16. Water temperature in the West Channel of the Uinta River and instream piezometers, Roosevelt Valley, Utah.-Continued 


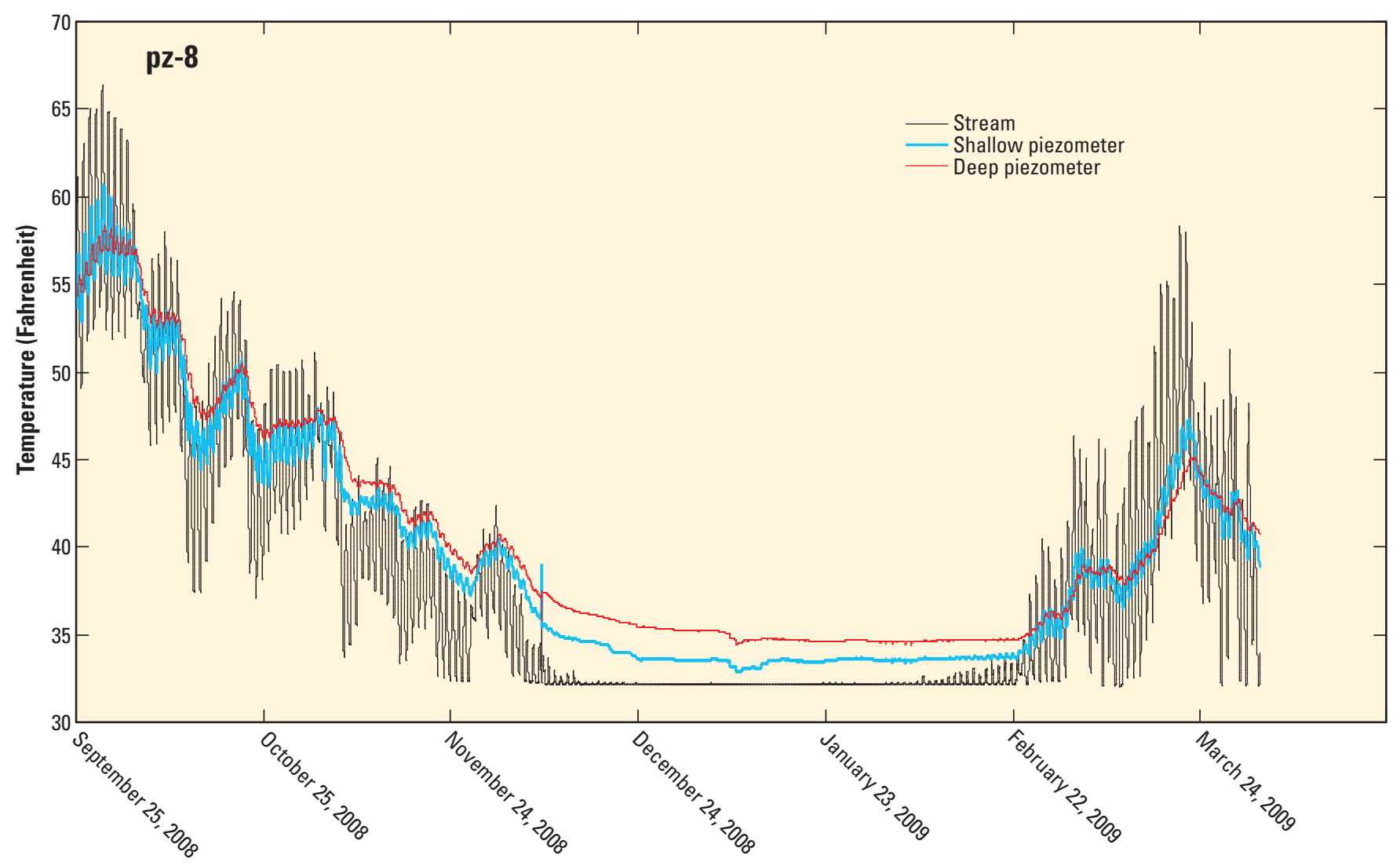

Figure 16. Water temperature in the West Channel of the Uinta River and instream piezometers, Roosevelt Valley, Utah.—Continued

show evidence of the changes in magnitude and, possibly, direction of flow during the study period at individual sites. As discussed previously, the direction and magnitude of flux across the streambed is dependent on the relative position of the elevation of the stage in the stream and the altitude of the water level in the adjacent aquifer (fig. 8). In the fall of 2008, the stage in the West Channel of the Uinta River at the Bench Canal (fig. 1) decreased approximately $1 \mathrm{ft}$ from October 5 to October 13 (fig. 17). Prior to that decline, streambed temperature fluctuations in piezometers pz-4 through pz-7, although damped, closely followed instream temperature fluctuations. Close examination of the traces of stream stage and stream and streambed temperatures at pz-4 (fig. 17) indicates that after stream stage fell to $0.5 \mathrm{ft}$ (after October 13,2008 ), the thermal response pattern in the streambed changed substantially. Temperature fluctuations in pz-4 were more damped in the shallow temperature sensor and almost nonexistent in the deep streambed temperature sensor after October 13, 2008. This response pattern persisted throughout the remainder of the data-collection period (through March 2009), with stream stage not exceeding $0.6 \mathrm{ft}$ during that time. This streambed temperature pattern may indicate that the stream reach in the area of pz-4 was a losing reach, or at least a very moderately gaining reach, when the stream stage was relatively high through October 13,2008 , and then became a strongly gaining reach after the observed stream-stage decline.
This pattern is also observed in piezometers pz-5, pz-6, and $\mathrm{pz}-7$; the pattern is less pronounced in pz-8 at the southern end of the study area. Temperatures were not measured during high-stage conditions in May and June, still this observed change in streambed temperature fluctuation with stream stage indicate that stream reaches in the southern half of the study area lose flow to groundwater, or gain less flow from groundwater, under high-stage conditions during spring runoff than under low-stage conditions during the late summer and the winter months.

\section{Numerical Model Simulation of Groundwater/Surface-Water Interaction}

A numerical groundwater flow model was developed to simulate flow in the glacial outwash aquifer and the underlying Duchesne River Formation in the study area. This numerical model is a simplified representation of the groundwater system and incorporates concepts of groundwater conditions and aquifer/stream interactions as defined in previous studies and from data collected during this study. 


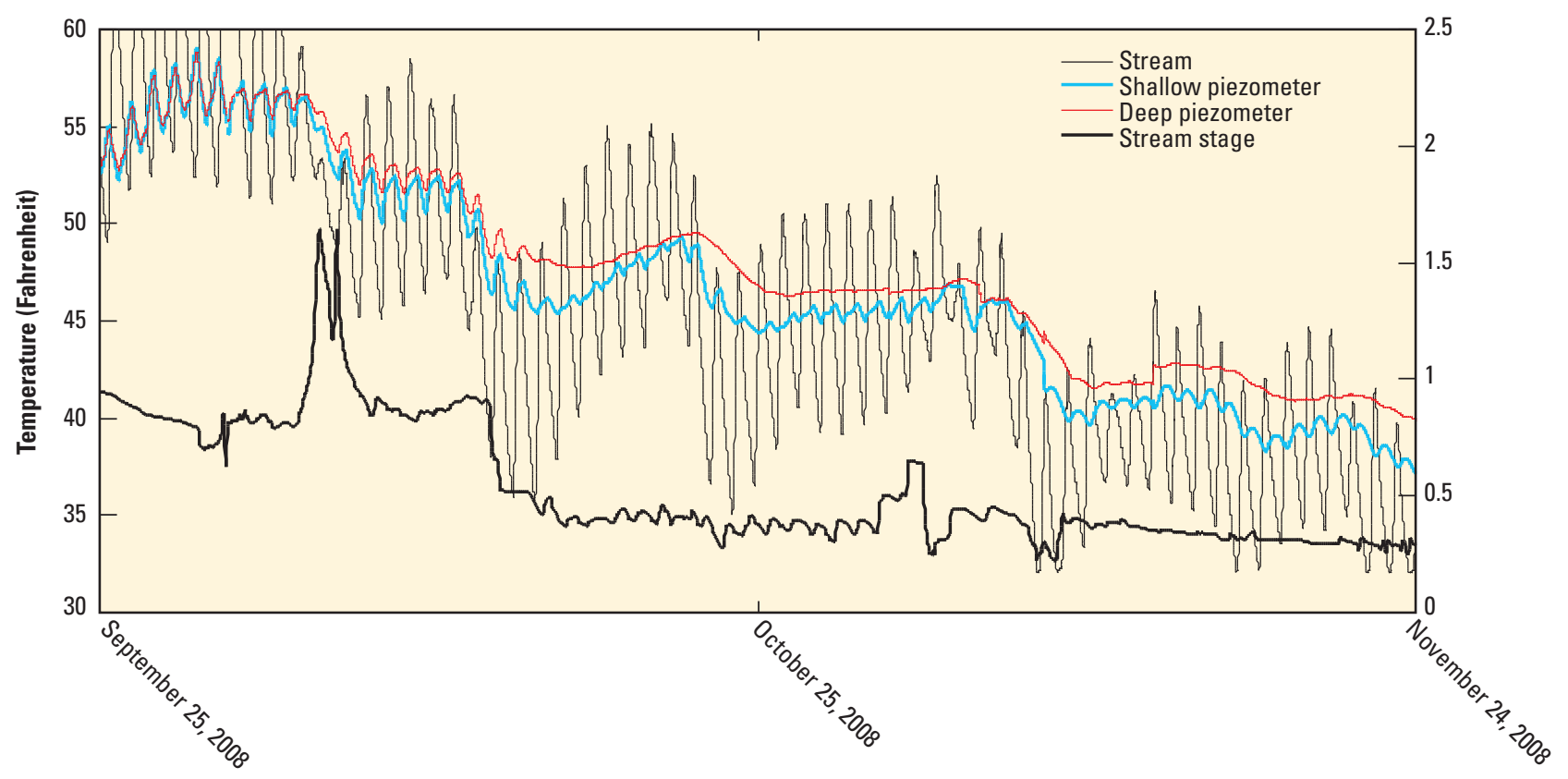

Figure 17. Daily stream stage in the West Channel of the Uinta River near the Bench Canal, Utah, and stream temperature and water temperature in piezometer pz-4, Roosevelt Valley, Utah.

\section{Modeling Approach}

The groundwater flow model was constructed using MODFLOW-2005, the most recent version of the USGS threedimensional, finite-difference MODFLOW groundwater flow model (Harbaugh, 2005). The model was used to simulate transient groundwater flow conditions within the study area with emphasis on representation of flow patterns and groundwater/surface-water interaction in the vicinity of the Sprouse well field (fig. 13). The model incorporates observed fluctuations in stream stage, groundwater withdrawals, and a general representation of seasonal groundwater-level fluctuations. Two transient-state models were constructed using the MODFLOW-2005 model code: (1) a simulation of observed hydrologic conditions for the study period from August 1, 2008, to July 31, 2009; and (2) predictive simulations of potential future conditions, including projected groundwater withdrawals from the Sprouse well for public supply.

The first simulation incorporated available hydrologic data from previous studies and the data collected during this study defining general hydrologic conditions, including groundwater/surface-water interaction, to represent studyperiod conditions from August 1, 2008, to July 31, 2009 (the 2008-09 simulation). The results of this simulation, including model-computed water levels and groundwater discharge to and recharge from the West Channel of the Uinta River, were compared to observed conditions to assess how well the numerical model represents the groundwater system.
The predictive model simulated and compared flow to and from the aquifer at its boundary with the West Channel of the Uinta River in future years under two conditions: (1) probable future groundwater withdrawals from existing public-supply wells (represented in the 2008-09 simulation) in the study area, and (2) probable groundwater withdrawals from existing public-supply wells and projected withdrawals from the Sprouse well in the Sprouse well field (fig. 2).

Potential streamflow depletion resulting only from the effects of simulated future withdrawals from the Sprouse well was estimated by comparing the results of the two predictive simulations.

The principal objectives of the modeling approach were to assess (1) groundwater/surface-water interaction, including streambed and aquifer properties in the area of the Sprouse well; and (2) potential streamflow depletion that could result from future groundwater withdrawals at the Sprouse well field. Although modeling objectives were focused on the Sprouse well field and vicinity, model boundaries (fig. 18) were extended beyond the well field to limit boundarycondition effects and to provide a simulation tool capable of representing groundwater flow patterns in the area surrounding the well field. The approaches to mathematically simulating the study-area groundwater system, including system discretization, definition of flow boundary conditions, and the assignment of boundary-condition and aquifer parameters, were selected to represent general water-level conditions throughout the modeled area with emphasis on the accuracy of the simulations at the Sprouse well field and the adjacent river boundary. 


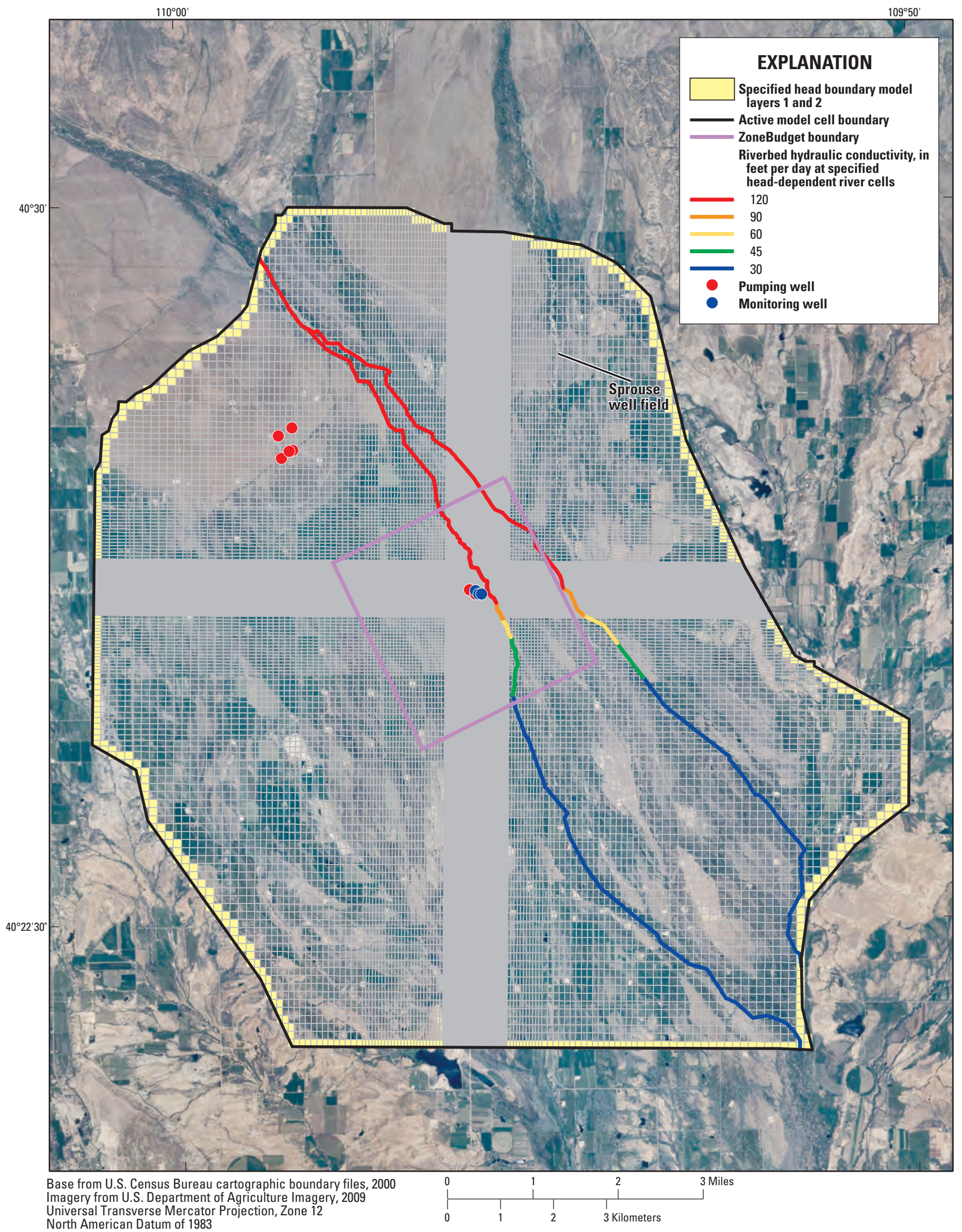

Figure 18. Grid, location of active cells, and boundary conditions in layers 1 and 2 in the groundwater flow model, Roosevelt Valley, Utah. 


\section{Discretization}

Areally, the model is discretized into a grid of rectangular cells (fig. 18); each cell has homogenous properties. The boundary of active cells delineates the lateral boundaries of the simulated groundwater system and corresponds to the extent of glacial outwash that forms the unconfined aquifer in the study area.

The rectangular model grid consists of 198 rows and 207 columns. Cell size within the model boundaries was varied so that the grid spacing is finer around the Sprouse well field and coarser in the surrounding areas. Active cells range in size from 50 to $500 \mathrm{ft}^{2}$. Given the close spacing of pumped and monitoring wells in the Sprouse well field and the proximity of those wells to the river, a cell size of $50 \mathrm{ft}^{2}$ is necessary to assign any given well to a unique cell. The groundwater flow equations are formulated at the center of each model cell. The area and gradient used to calculate flow through the cell are determined at the center of the cell and represent the average area and gradient of flow through the cell.

Vertically, the model comprises two layers. Model layer 1 , the upper layer, represents the entire thickness of the unconfined glacial outwash aquifer, which ranges in thickness from approximately $300 \mathrm{ft}$ at the northern end of the modeled area to $50 \mathrm{ft}$ at the southern boundary. Model layer 2, the lower layer, represents the confined Duchesne River Formation aquiclude and was assigned a constant thickness of $500 \mathrm{ft}$. The specified thickness of model layer 2 closely matches the thickness of the predominantly fine-grained Dry Gulch Creek Member of the upper part of the Duchesne River Formation in the study area (Anderson and Picard, 1972). The Duchesne River Formation in the vicinity of the study area is assumed to be substantially less permeable than the overlying glacial outwash aquifer and therefore is generally not a significant part of the groundwater flow system utilized for public supply. The model includes this layer, however, to enable the assessment and interpretation of the November 2008 aquifer-test results and the possibility of leakage of groundwater from the Duchesne River Formation to the glacial outwash aquifer under different groundwater-withdrawal scenarios in the predictive model simulations.

Temporally, the model was designed to simulate yearly periods of varying hydrologic conditions that are a result of three general stresses: the seasonal variation in regional groundwater levels over the model domain, the variation in stage in the Uinta River, and the variation in pumping rates from the Hayden and Sprouse well fields. To achieve this representation, the 2008-09 simulation was divided into 52 week-long stress periods with three time steps per period. This stress-period pattern was used consistently throughout the 2008-09 simulation except during the November aquifer test, which was 11 days long. To represent the aquifer-test stress period, one 7-day stress period was replaced with two stress periods, the first being 4 days long and the second being 3 days long, to allow for accurate timing replication in the model. Predictive model simulations incorporated possible groundwater-withdrawal scenarios that required using 12-hour stress periods during the summer months.

\section{Flow Boundary Conditions}

The groundwater flow model requires that specific types of mathematical boundaries be assigned to the groundwater system to simulate flow at surface boundaries and internal sources and sinks. The flow boundary can simulate no-flow conditions, recharge to the groundwater flow system, or discharge from the system.

Recharge to and discharge from the study-area groundwater flow system, other than as seepage along the Uinta River and discharge to wells, were simulated using specified-head boundaries implemented through the MODFLOW Time-Variant Head Package (Leake and Prudic, 1991, p. 68). The active model-cell boundary (fig. 18) is surrounded by a specified-head boundary that simulates (1) the water-level altitude in the unconfined glacial outwash aquifer, represented by model layer 1, at the boundary location; and (2) the potentiometric surface in the Duchesne River Formation, represented by model layer 2, at the boundary location.

This boundary-condition approach was used to simulate a distribution of recharge and discharge that would result in the generally observed water-level and potentiometric-surface conditions and the observed seasonal variation in water levels in the modeled area.

Initial specified heads for layer 1 were based on contoured water-level measurements made during this study (fig. 5). Only two wells screened in the Duchesne River Formation within the study area could be measured for water levels; therefore, specified heads in layer 2 were based on a potentiometric surface defined from water levels measured prior to 1976 by Hood and Fields (1978) (fig. 4b).

Water-level fluctuations in the glacial outwash aquifer measured during this study (fig. 6) indicated a general rise in groundwater levels from the spring through early to mid summer followed by a gradual decline through the fall and winter months. The average amplitude of the groundwater fluctuation was approximately $5 \mathrm{ft}$. This observed seasonal variation in groundwater levels was simulated in the model by varying the head at specified-head boundaries in layer 1 throughout the annual simulation according to an input function that reflects a similarly timed head fluctuation with an amplitude of $5 \mathrm{ft}$ (fig. 19). Values produced by the input function were added to the starting specified-head values for each stress period. This specified-head fluctuation pattern was incorporated in both the 2008-09 and predictive simulations to produce the general average distribution of head with time in the model domain. The historic water-level data needed to define seasonal fluctuations in water levels in the Duchesne River Formation aquiclude throughout the study area are limited; however, data presented by Hood and Fields (1978) indicate damped responses to seasonal and long-term variations in recharge and discharge compared to those in the glacial outwash aquifer. Therefore, water levels at 


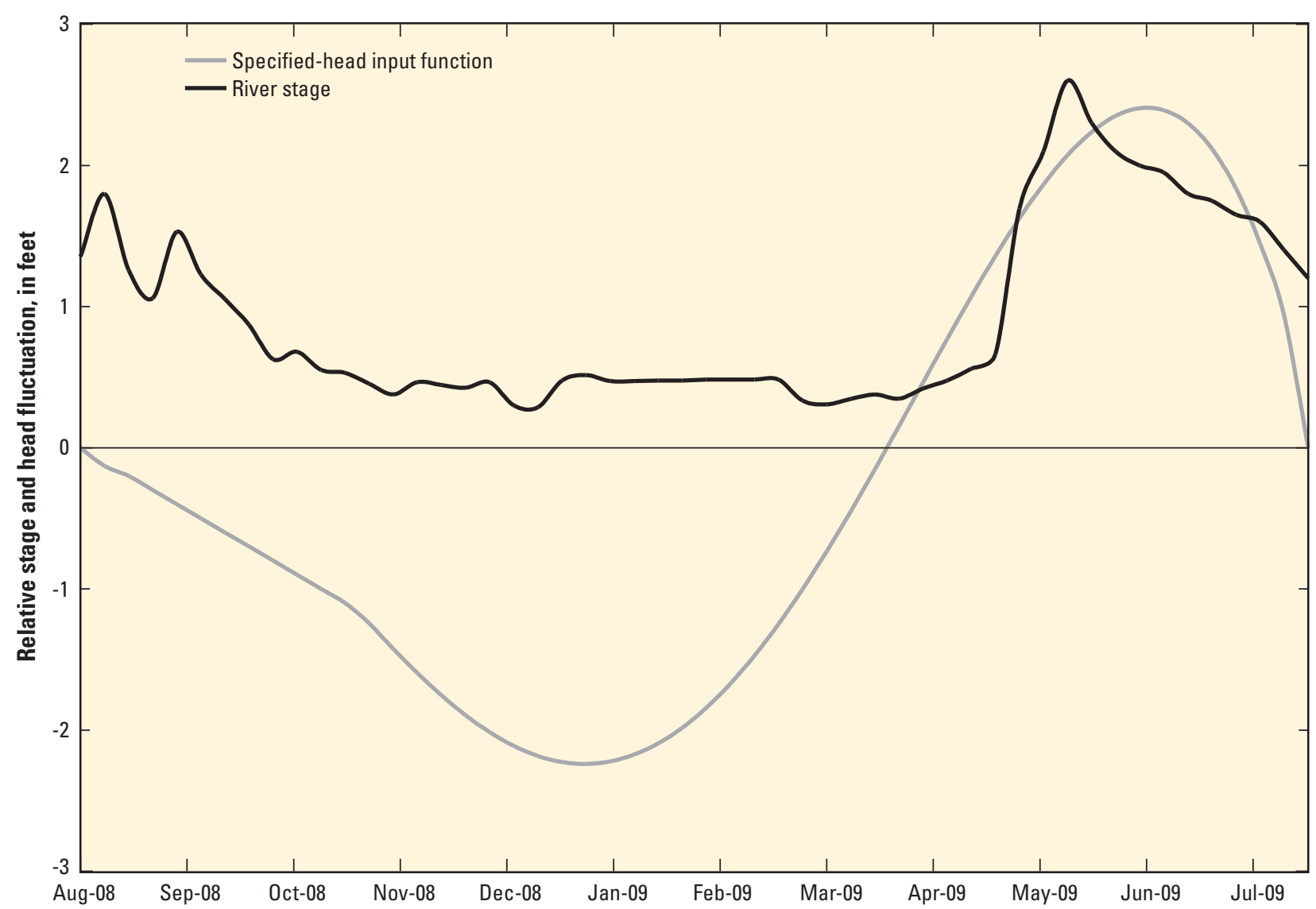

Figure 19. Simulated River stage at head-dependent river cells and input function used to adjust head with time from initial values at specified-head boundaries in the groundwater flow model, Roosevelt Valley, Utah.

specified-head boundaries in model layer 2 were not changed through time, but remained constant at the values defined in the potentiometric surface presented by Hood and Fields (1978).

The model-boundary approach described above is a gross simplification of the actual recharge distribution in the study area in that all recharge to and discharge from the modeled system, other than seepage to and from the Uinta River and well discharge, are simulated as subsurface inflow or outflow at the margins of the study area. Although subsurface recharge is likely a substantial component of groundwater flow to and through the study and modeled area, a portion of total annual recharge within the modeled area is derived from other sources, such as seepage from canals or percolation of unused irrigation water and precipitation. Also, some discharge from the glacial outwash aquifer within the study area occurs as evapotranspiration and, possibly, as seepage to canals or drains. Although not explicitly represented in model simulations, the selected boundary-condition approach achieves representation of the cumulative effects of these distributed sources and sinks on water-level conditions observed during the study.
Recharge from the East and West Channels of the Uinta River to groundwater in the modeled area and groundwater discharge to those streams were simulated as a head-dependent boundary using the MODFLOW River Package (Harbaugh, 2005). Flow between the river and the adjacent aquifer at a given cell containing a river boundary (river cell) (fig. 18) is simulated according to the following equations (Harbaugh, 2005, p. 81):

$$
\begin{gathered}
Q R I V=C R I V(H R I V-h), \text { if } h>R B O T \\
Q R I V=C R I V(H R I V-R B O T), \text { if } h<=R B O T
\end{gathered}
$$

where:
QRIV is flow to or from the river $\left(\mathrm{L}^{3} \mathrm{~T}^{-1}\right)$,
CRIV is hydraulic conductance of the river-aquifer interconnection $\left(\mathrm{L}^{2} \mathrm{~T}^{-1}\right)$,
HRIV is specified water level in the river (L),
$h \quad$ is model-computed water level in the cell containing the river boundary $(\mathrm{L})$, and
$R B O T$ is altitude of the river-bottom sediment $(\mathrm{L})$. 
No flow to the river is simulated at a river boundary when $h$ is less than or equal to HRIV. For larger values of $h$, flow from the aquifer to the river is simulated. Flow from the river to the aquifer increases linearly as $h$ decreases, until $h$ reaches $R B O T$; thereafter, flow remains constant. Values of $R B O T$ for river-boundary cells were defined from topographic maps (U.S. Geological Survey, 1991). Within approximately $1 \mathrm{mi}$ up- and downstream from the Sprouse well field, RBOT values were determined during this study from survey data obtained from a real-time kinematic global positioning system (RTKGPS). Horizontal- and vertical-coordinate data surveyed with RTK-GPS were collected relative to a portable base station set up over a temporary stable reference point near the Sprouse well field. HRIV values for river-boundary cells (fig. 18) were defined as the weekly moving average river-stage value computed from continuous stream-stage measurements made at the West Channel of the Uinta River near the Bench Canal gage (fig. 19) (Duchesne County Water Conservancy District, 2009) by the Duchesne County Water Conservancy District, Duchesne/Strawberry River Water Users Association, and Moon Lake Water Users Association.

The simulated amount of water transmitted between the glacial outwash aquifer and the river is a function of the riverbed conductance (CRIV). The riverbed conductance within the River Package represents a solution to the following internal equation solved by MODFLOW:

where:

$$
C R I V_{n}=\frac{K_{n} L_{n} W_{n}}{M_{n}} \quad \text { (Harbaugh, 2005) }
$$

$$
\begin{aligned}
& C R I V_{n} \quad \text { is calculated riverbed conductance, } \\
& K_{n} \quad \text { is vertical hydraulic conductivity of the } \\
& \text { riverbed material }\left(\mathrm{LT}^{-1}\right) \text {, } \\
& L_{n} \quad \text { is length of the river as it crosses an individual } \\
& \text { cell }(\mathrm{L}) \text {, } \\
& W_{n} \quad \text { is river width (L), and } \\
& M_{n} \quad \text { is thickness of the riverbed material (L). }
\end{aligned}
$$

For the entire length of the Uinta River, the width $\left(W_{n}\right)$ was set to $25 \mathrm{ft}$, and the thickness of the riverbed material $\left(M_{n}\right)$ was set to $15 \mathrm{ft}$. The length $\left(L_{n}\right)$ of any river cell is set by the spatial discretization of the model domain. The vertical hydraulic conductivity of the streambed $\left(K_{n}\right)$ was initially specified at $30 \mathrm{ft} / \mathrm{d}$ and was varied over a reasonable range of values during model development and calibration.

Specified-flux boundaries were used to simulate discharge from the groundwater flow system by public-supply wells in the Hayden well field and the Sprouse well field (fig. 1). Detailed weekly pumping schedules provided by Roosevelt City for the wells in the Hayden and Sprouse well fields were represented in the 2008-09 simulation (fig. 20). The Hayden well field accounted for the bulk of the annual pumping during the simulation period, and specified-flux boundaries representing those wells were assigned discharge rates ranging from approximately $400 \mathrm{gal} / \mathrm{min}$ in winter months to 2,300 $\mathrm{gal} / \mathrm{min}$ in summer months. This same pattern of discharge for the Hayden well field was also incorporated in the predictive simulations. The Durigan public-supply well was completed in 2004 and has generally been used as a source of supplementary supply in the summer; however, some pumping occurred in the winter months during the study period (fig. 20) and is represented in the 2008-09 simulation. Predictive simulations incorporate a discharge rate of $300 \mathrm{gal} / \mathrm{min}$ for the Durigan well from June through September. Discharge rates for the Sprouse well during the November 2008 aquifer test (fig. 20) were incorporated in the 2008-09 simulation. A discharge rate of 1,200 gal/min from layer 1 for the Sprouse well, a potential public-supply source, was incorporated in the predictive simulations in two scenarios discussed farther on in the report.

\section{Aquifer Properties}

Model layers 1 and 2 represent, respectively, the permeable, unconfined glacial outwash aquifer and the underlying low-permeability Duchesne River Formation aquiclude. In model layer 1 , transmissivity varies spatially as a function of the saturated thickness of the layer and the specified horizontal hydraulic conductivity of the sediments in the layer. In model layer 2, saturated thickness was assumed to remain constant and equal to the aquiclude thickness (500 ft); therefore, transmissivity was specified in all simulations as the product of horizontal hydraulic conductivity and simulated layer thickness (500 ft). Horizontal hydraulic conductivity of model layer 1 was defined on the basis of results of aquifer testing in a previous study (Horrocks Engineering, 2004) and the November 2008 aquifer test conducted during this study (table 3). For most of the model domain, the hydraulic conductivity was initially set equal to $10 \mathrm{ft} / \mathrm{d}$. Hydraulic conductivity was set equal to $25 \mathrm{ft} / \mathrm{d}$ for model cells in and around the Hayden well field (Horrocks Engineering, 2004.). Hydraulic conductivity was varied within a reasonable range only in the vicinity of the Sprouse well field during model development and calibration. The specific yield for the model domain was set at 0.10 and was not varied during model calibration.

Vertical flow between model layers 1 and 2 was simulated as a function of equivalent vertical hydraulic conductivity and the thickness of saturated sediments present between the midplanes of the two layers. Vertical leakage between layers 1 and 2 at a given cell within the active model domain was simulated according to the following equation (Harbaugh, 2005, p. 54):

$$
\begin{gathered}
Q=C\left(h_{1}-h_{2}\right) \text {, and } \\
C=K_{v} A / L
\end{gathered}
$$

where:

$$
\begin{gathered}
Q \quad \begin{array}{c}
\text { is the volumetric flow, which is equal to } \\
\text { vertical leakage }\left(\mathrm{L}^{3} \mathrm{~T}^{-1}\right),
\end{array} \\
\text { is the conductance of the material in the } \\
\text { direction of flow }\left(\mathrm{L}^{2} \mathrm{~T}^{-1}\right),
\end{gathered}
$$




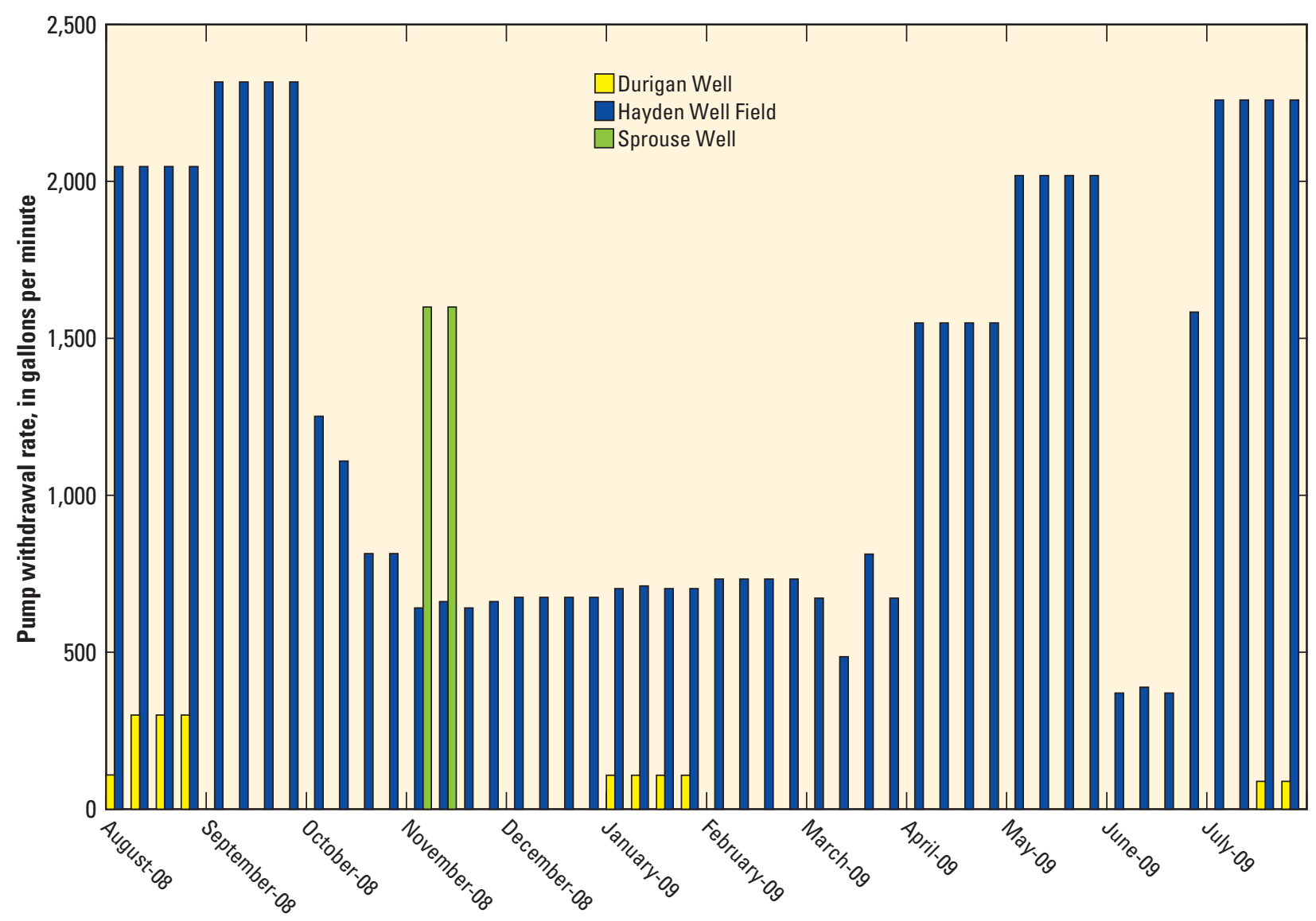

Figure 20. Weekly groundwater withdrawals from production wells and the Sprouse well incorporated in the 2008-2009 groundwater flow model simulation, Roosevelt Valley, Utah.

$K_{v} \quad$ is the vertical hydraulic conductivity of the material in the direction of flow $\left(\mathrm{LT}^{-1}\right)$,

$A \quad$ is the cross-sectional area perpendicular to the flow $\left(\mathrm{L}^{2}\right)$, and

$L \quad$ is the length of the prism parallel to the flow path.

The vertical leakage between layers 1 and 2 is calculated by multiplying the head difference $\left(h_{1}-h_{2}\right)$ by the vertical conductance between adjacent cells in layers 1 and 2 . The vertical conductance is calculated as the harmonic mean of conductance for half cells in adjacent layers. Initially, $K_{v}$ for layer 1 was set to $0.1 \mathrm{ft} / \mathrm{d}$. $K_{v}$ for layer 2 was set to $1.0 \times 10^{-5}$ $\mathrm{ft} / \mathrm{d}$, on the basis of calculations of the hydraulic conductivity of the Duchesne River Formation by Hood and Fields (1978).

\section{8-09 Model Simulation, Model Calibration, and Model Accuracy}

The 2008-09 model simulation is a simplified representation of the study-area groundwater flow system and hydrologic conditions from August 1, 2008, to July 31, 2009, and was developed on the basis of available hydrologic data obtained from previous studies and observations made during this study. The model incorporates concepts of transient groundwater flow conditions, including fluctuations in groundwater levels and storage, and the distribution and temporal variation in gains to and losses from streamflow in the Uinta River near the Sprouse well field. The development of the simulation, the calibration of selected model parameters to observed conditions, and the accuracy of the model in representing those conditions are discussed below.

For the transient-state 2008-09 simulation, initial conditions defining the head distribution in the aquifer at the beginning of the simulation were required. To minimize the effects of the initial conditions on the simulation results, 1-year-period simulations were run consecutively until the change in head from one 1-year simulation to the next was less than $0.1 \mathrm{ft}$. This criterion was achieved after 30 annual simulations. The 30-year simulation incorporated historical discharge from the Hayden well field but did not include discharge from the Sprouse well field, which had been active as a public-supply source for only 4 years prior to this study. After stabilization was achieved, the model was run for 4 years, incorporating discharge from the Durigan well in the Sprouse well field with a simulated discharge of $300 \mathrm{gal} / \mathrm{min}$ for 4 summer months (June-September). The ending heads 
from this 4-year simulation were saved and used as starting head conditions for the 2008-09 transient-state simulation.

Reported discharge at the Hayden well field and the Sprouse well field, including pumping at the Sprouse well during the November 2008 aquifer test (fig. 20), was represented in the 2008-09 simulation. Calibration of model parameters was limited to modification of riverbed conductance and hydraulic conductivity in the vicinity of the Sprouse well field to improve the match between (1) modelcomputed water levels in layer 1 and observed water levels in three monitoring wells (MW 1, MW 2, and MW 3) near the Sprouse well field (fig. 2), and (2) model-computed and observed gaining/losing conditions in four reaches of the West Channel of the Uinta River (fig. 11).

In general, results of the 2008-09 simulation indicate a good match between model-computed and observed water levels throughout the model domain and that the model represents the general groundwater flow patterns determined from field observations (fig. 21). Water levels measured in August 2008 in most of the observation wells were generally within 5 to $15 \mathrm{ft}$ of model-computed water levels for the corresponding time period. Differences between modelcomputed and observed water levels near the Sprouse well field were generally not greater than $5 \mathrm{ft}$ (fig. 21).

During calibration, hydraulic conductivity in a zone extending northwest of the Sprouse well (fig. 22) was increased from the initially specified $10 \mathrm{ft} / \mathrm{d}$ to range from 10 to $60 \mathrm{ft} / \mathrm{d}$ to match pumping-induced drawdown and recovery trends measured in nearby observation wells (fig. 23).

Variations in hydraulic conductivity west of the Sprouse well are derived from drawdown solutions in the November 2008 aquifer test. The large variation in well discharge capacities in the Sprouse well field and the results of the November 2008 aquifer test indicate that aquifer properties in the study area are heterogeneous and that hydraulic conductivity may be greater in a zone at and northwest of the Sprouse well than elsewhere near the well. The distribution of riverbed conductance was also adjusted at the adjacent Uinta River boundary (fig. 18) to match the post-pumping recovery curve in the three observation wells (fig. 23) and general net gain and loss estimated from results of the November 2008 slug tracer injections (table 7). Riverbed conductivity values used for final riverbed conductance range from $30 \mathrm{ft} / \mathrm{d}$ in the southern part of the study area to $120 \mathrm{ft} / \mathrm{d}$ in the northern part of the model domain (fig. 18). In some areas, slight adjustments to riverbed elevation with respect to local groundwater levels were made to account for discrepancies between model-computed and observed water levels in the Sprouse monitoring wells. Simulation results using the final aquifer and streambed properties indicate a good match between computed and observed water-level fluctuations in wells MW 1, MW 2, and MW 3 in response to withdrawals from the Durigan well over the 2008-09 simulation period and from the Sprouse well during the November 2008 aquifer test (fig. 23).
Simulated net gaining/losing conditions (fig. 24) in defined river reaches of the West Channel of the Uinta River (fig. 11) are in general agreement with estimates made from the results of the November 2008 slug and continuous tracerdilution discharge measurements, and qualitative observations of direction of flow in the streambed made on the basis of vertical hydraulic gradients (table 6 and fig. 14) and streambed temperature (fig. 16). Results of the 2008-09 simulation indicate both gains and losses in each of the tracer-dilution measurement reaches. The net rate values shown in figure 24 represent the difference between the model-computed gains and losses in a given reach. For example, results of the 2008-09 simulation indicate loss at some river cells in reach 4, but at most cells streamflow gains are simulated; therefore, the net seepage rate for the reach indicates a predominantly gaining reach throughout the simulation period. The 2008-09 model simulates generally losing stream conditions similar to those observed in field data in the reach north of and upstream from the Sprouse well field, and generally gaining conditions south of and downstream from the well field. For stream reaches 2 and 3, which generally were simulated as gaining stream reaches, the simulation results indicate a brief period of streamflow loss (fig. 24) associated with high stream stage during spring runoff. Losing stream conditions south of and downstream from the Sprouse well field during relatively high stage conditions were also indicated by the streambed temperature data (fig. 17). Model-simulated predominantly gaining conditions in reach 4 are consistent with the assessment of flow based on vertical hydraulic gradient measurements and streambed temperature measurements in that area, but are not consistent with the estimated net streamflow loss computed from slug tracer-injection measurements.

In addition to calibration of the model to water-level fluctuations near the Sprouse well field and losing and gaining reaches of the West Channel of the Uinta River, groundwater flow across the specified-flux boundaries at the active border of the model area was evaluated for anomalous values. Model-computed flow at the boundary of the active model domain generally agreed with calculations of groundwater flow through the study area made by using a Darcy's Law calculation for corresponding aquifer geometries, properties, and groundwater flow gradients.

\section{Model Limitations and Utility}

One limitation of the model's representation of water levels is the limited period of data collection (approximately 12 months, from August 2008 to August 2009) used to define conditions in the model area. There are few historical waterlevel data for the glacial outwash aquifer in the model area and none in the vicinity of the Sprouse well field from which to assess fluctuations in local water-table altitudes relative to long-term averages in the area resulting from variability in climatic conditions. As has been discussed, however, precipitation in the region prior to and during the period 


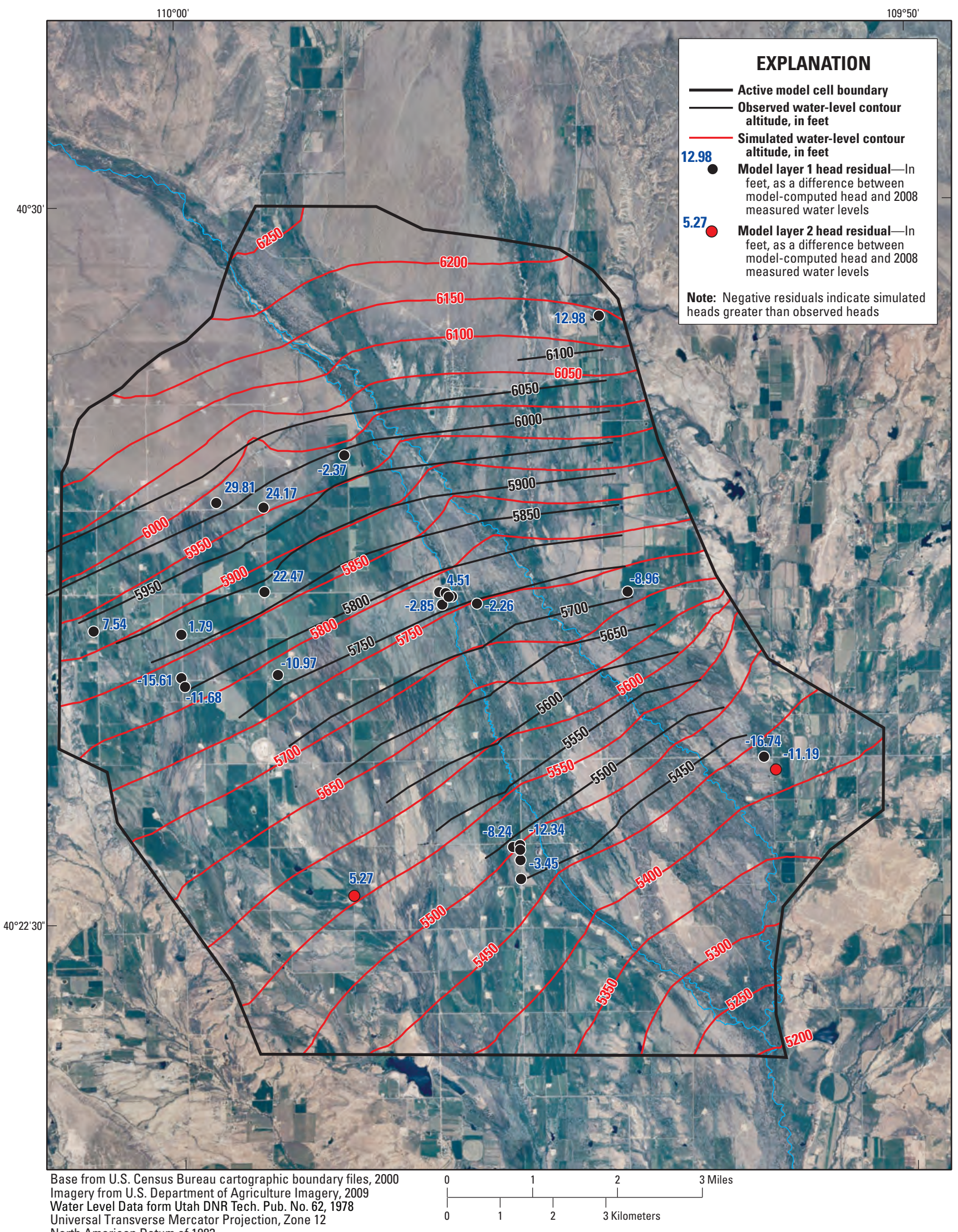

Figure 21. Model-computed altitude of water table in model layer 1 and the difference between water levels measured in August 2008 at wells in the glacial outwash aquifer and model-computed water levels representing August 2008, Roosevelt Valley, Utah. 


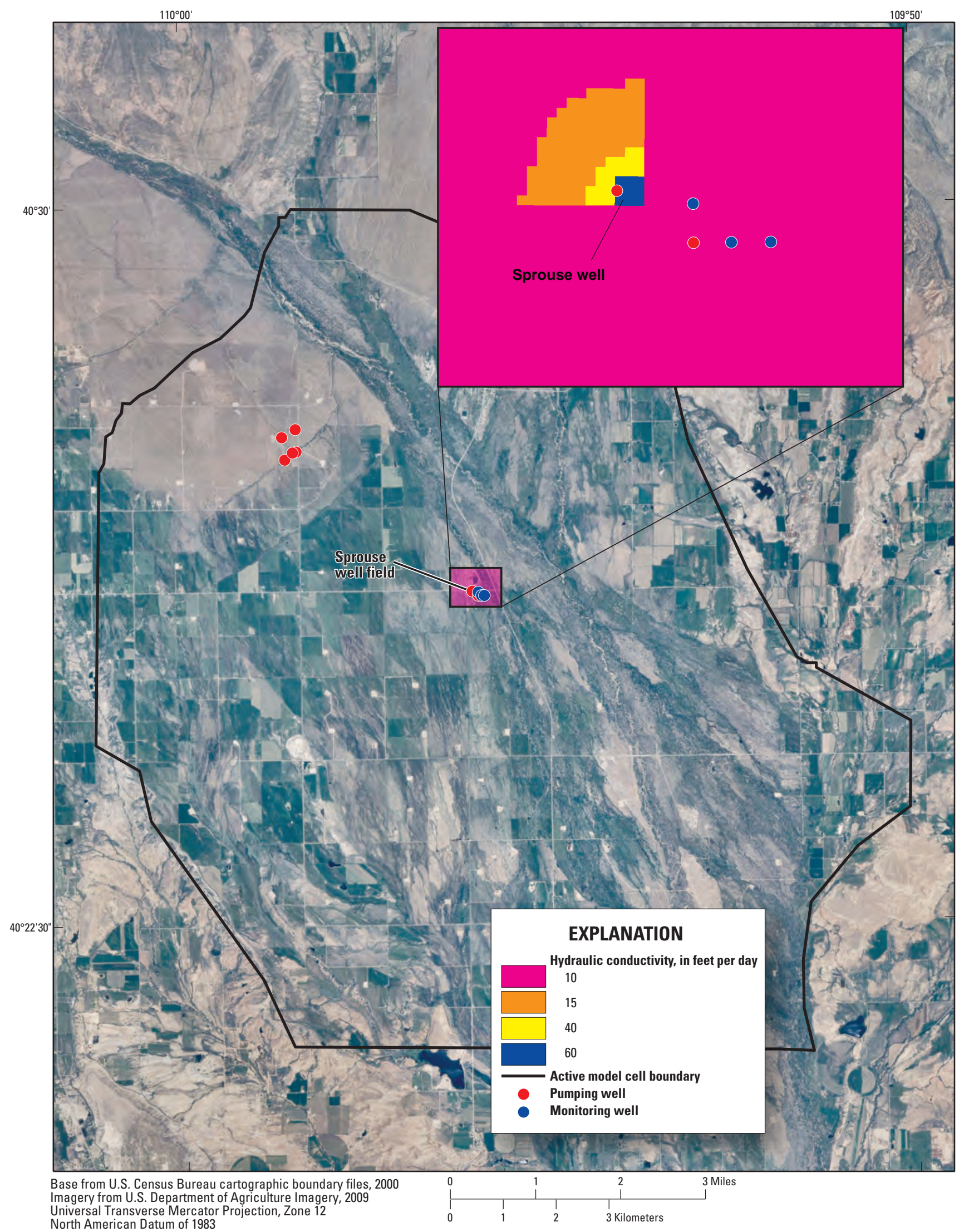

Figure 22. Final distribution of hydraulic-conductivity values for model layer 1 in the groundwater flow model, Roosevelt Valley, Utah. 

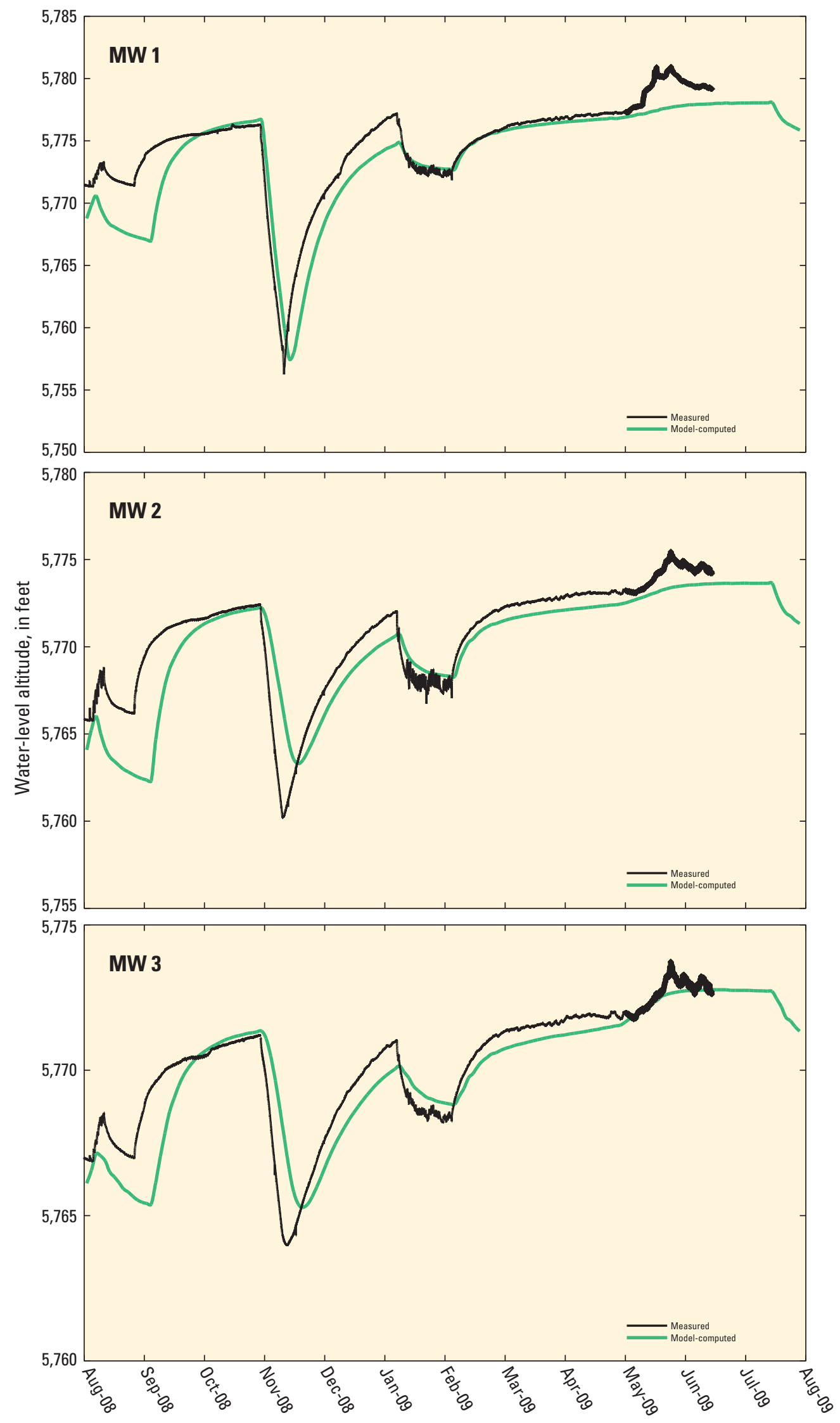

Figure 23. Model-computed and measured water-level changes at monitoring wells in the Sprouse well field, Roosevelt Valley, Utah. 


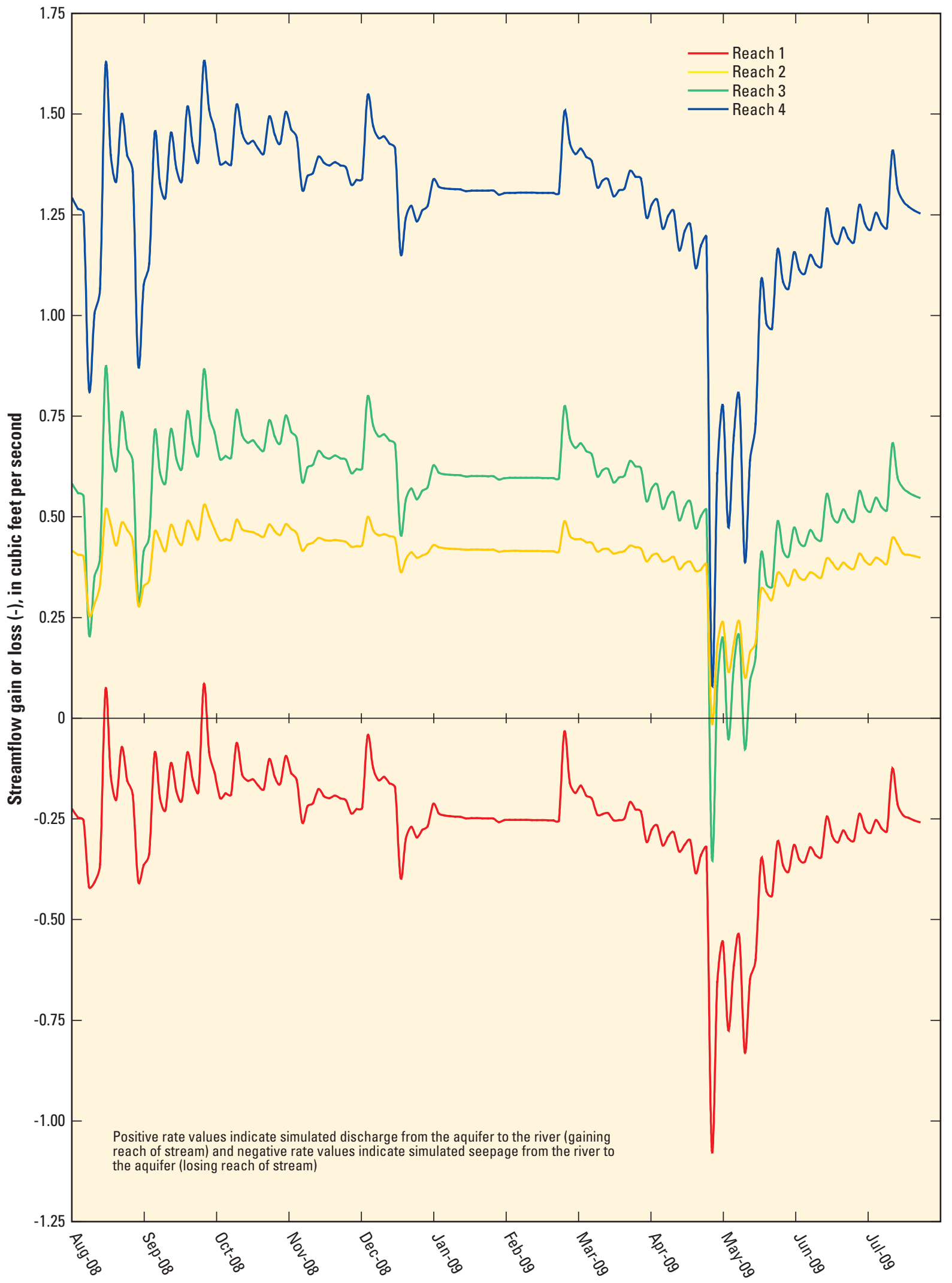

Figure 24. Model-computed net gain to or loss from the West Channel of the Uinta River, Utah, simulated from August 1, 2008-July 31, 2009, Roosevelt Valley, Utah. 
Table 7. Comparison of model-computed net gaining/losing conditions and observed gaining/losing conditions in the West Channel of the Uinta River, Roosevelt Valley, Utah.

[ $\mathrm{ft}^{3} / \mathrm{s}$, cubic feet per second]

\begin{tabular}{ccccc}
\hline Location & $\begin{array}{c}\text { Model-computed net streamflow } \\
\text { gain or loss (-) for stress period } \\
\text { representing November 2008 } \\
\left(\mathbf{f t}^{3} / \mathbf{s}\right)\end{array}$ & $\begin{array}{c}\text { Estimated net streamflow gain or } \\
\text { loss (-) from November 2008 } \\
\text { slug tracer test } \\
\left(\mathbf{f t}^{3} / \mathbf{s}\right)\end{array}$ & $\begin{array}{c}\text { Predominantly gaining or losing } \\
\text { condition indicated from vertical } \\
\text { hydraulic gradient measurements } \\
\text { (September 2008-April 2009) }\end{array}$ & $\begin{array}{c}\text { Predominantly gaining or } \\
\text { losing condition indicated } \\
\text { from continuous streambed } \\
\text { temperature measurements } \\
\text { (September 2008-April 2009) }\end{array}$ \\
\hline Reach 1 & -0.20 & -1.0 & Losing & Losing \\
Reach 2 & 0.47 & 0.60 & 1 Gaining & Gaining \\
Reach 3 & 0.70 & 0.50 & Gaining & Gaining \\
Reach 4 & 1.44 & -1.0 & Gaining & Gaining \\
\hline
\end{tabular}

${ }^{1}$ Vertical hydraulic gradient observed in piezometer pz4 located at the upstream end of reach 2 indicated a potential losing condition at that location.

of data collection for this study represents near-average conditions. Therefore, it can be assumed that the distribution of water levels specified in the 2008-09 simulation and in predictive simulations using the 2008-09 specified-head boundary condition generally are fair representations of nearaverage flow conditions.

The boundary conditions incorporated in the model were selected to simulate seasonal variations in the altitude of the water table in the glacial outwash aquifer and do not explicitly represent some components of recharge and discharge that occur within the study area. For example, discharge from Uriah Heap Spring, located $1.65 \mathrm{mi}$ east of the Sprouse well field and east of the East Channel of the Uinta River, is not explicitly represented in the model; therefore, depletion of flow to this spring resulting from increased groundwater withdrawals at the Sprouse well field was not directly assessed. However, computed water levels in the vicinity of the spring did not decline in either predictive simulation (fig. 25), and the area near the spring was unaffected by the simulated increase in pumping west of the West Channel of the Uinta River.

The distribution of hydraulic conductivity, including vertical hydraulic conductivity in the study area and in the vicinity of the Sprouse well field, is likely very complex. The probable substantial heterogeneity of the glacial outwash aquifer cannot be defined with available data. The 2008-09 simulation and the predictive simulations use simple representations of aquifer properties to simulate flow to the Sprouse well field and to and from the adjacent river, and do not capture the variations in aquifer properties that appear to exist in the vicinity of the Sprouse well field, even at the scale of hundreds of feet. In general, however, the 2008-09 model does reproduce the observed water-level conditions in model layer 1 and the water flux at the aquifer/stream boundary accurately. Therefore, the model simulations are considered to be useful for assessing the effects of future stresses on aquifer/ stream relations.

\section{Simulation of Projected Groundwater Withdrawal}

Potential streamflow depletion from the Uinta River for a possible range of groundwater withdrawals from the Sprouse well in the Sprouse well field was assessed in three steps. In the first step, flow in the groundwater/ surface-water system was simulated without the additional withdrawal from the Sprouse well to simulate estimated baseline values of all groundwater budget components in the model, including groundwater discharge to the river and recharge to groundwater from the river. The second step was to rerun the simulation with no other changes except the addition of projected withdrawals from the Sprouse well. Finally, the results of the two simulations were compared and changes in values of water-budget components between the baseline simulation and the projected (addition of Sprouse well withdrawals) simulation were computed for selected simulation times and pumping schemes. This approach was used to assess the source of water (including streamflow depletion) to the new Sprouse well.

Roosevelt City estimated that the Durigan publicsupply well would continue to be pumped at $300 \mathrm{gal} /$ min in future summer months and that the new Sprouse public-supply well, if used, would be pumped at 1,200 gal/ min from June 1 through September 30 of future years, for a total withdrawal of approximately 325 acre-ft annually. The additional groundwater discharge was represented in predictive simulations using two pumping scenarios for the period June through September. Both scenarios included 12 hours of pumping at $1,200 \mathrm{gal} / \mathrm{min}$ and 12 hours of inoperable status each day from June through September. The 2008-09 simulation model was rediscretized temporally to accommodate the half-day on/half-day off projected pumping scenario defined by Roosevelt City. The first simulation incorporated pumping at the new Sprouse public-supply well in the summer of each simulated year. The second simulation incorporated pumping at the Sprouse well in the summer every other year, transferring the additional 1,200 gal/min to the 


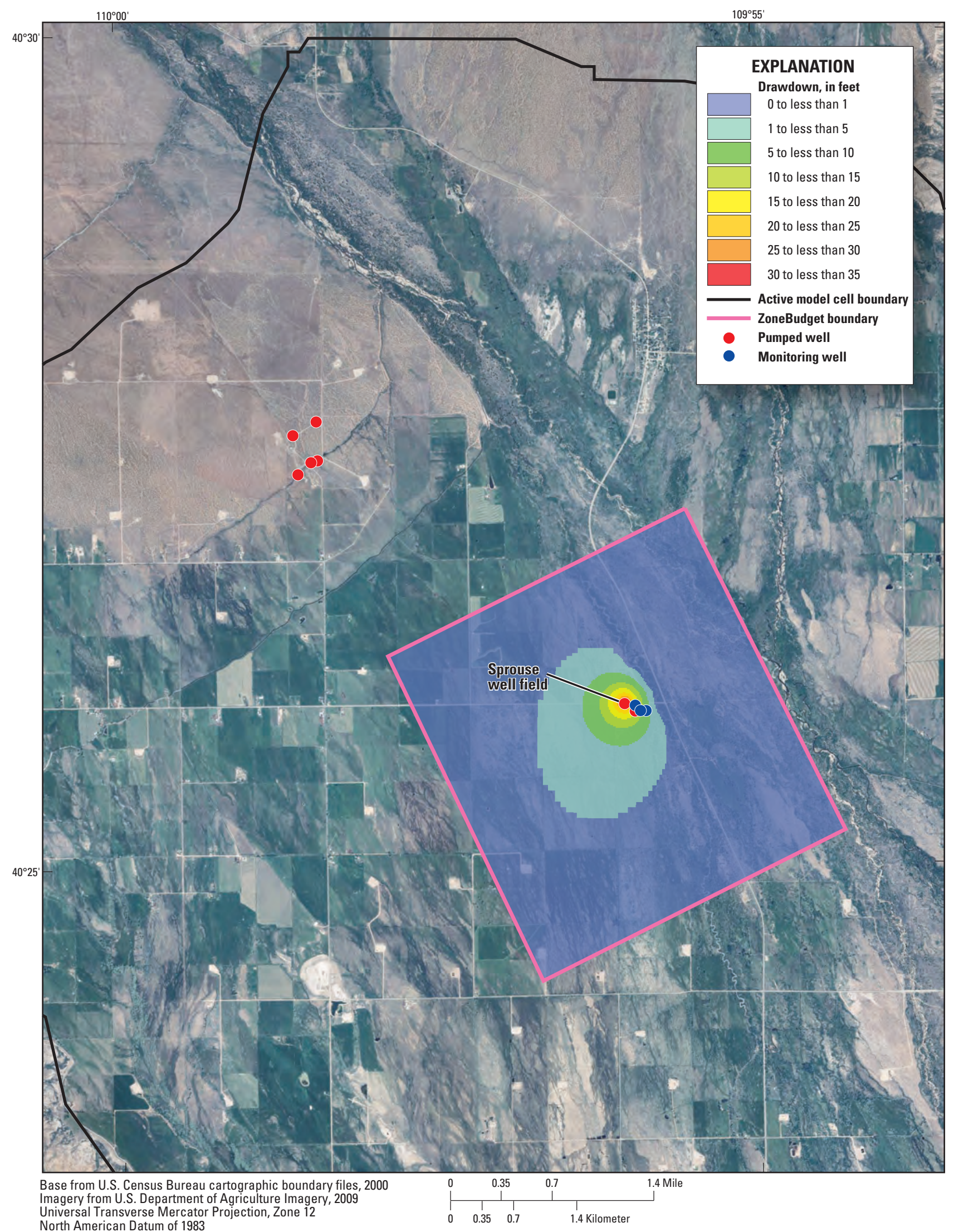

Figure 25. Model-computed drawdown in layer 1 after 10 years based on simulation of potential annual summer groundwater withdrawal from the Sprouse well, Roosevelt Valley, Utah. 
Hayden well field in the years that the Sprouse well field was not being pumped. The baseline and projected Sprouse well predictive simulations were compared to calculate annual and monthly flow budgets for a 10 -year period.

The annual and monthly budgets were calculated with the ZoneBudget 3.0 software package (Harbaugh, 1990), a computer program that computes subregional water budgets using results from the MODFLOW groundwater flow model. The user designates the subregions by specifying zone numbers. A separate budget is computed for each zone. The dimensions of the ZoneBudget zone used to account for the effects of pumping at the Sprouse well are approximately 2 mi by $2 \mathrm{mi}$, with the Sprouse well at the center (figs. 18 and 25). The dimensions of the zone were determined by trial and error, resulting in an area that was large enough to capture most of the water sources that would accommodate the 325-acre-ft/yr pumping demand, but small enough to reduce background processes so that the volume of water discharged from the Sprouse well was a substantial portion of the annual budget. All results for simulated sources of Sprouse well discharge were derived from calculations of the budget for the 4-mi ${ }^{2}$ ZoneBudget zone. Identified sources of Sprouse well discharge include (1) aquifer storage, (2) streamflow depletion, (3) flow from the underlying Duchesne River Formation, and

(4) flow from outside the budget zone.

The use of ZoneBudget to identify the sources of the water withdrawn from the Sprouse well is subject to the same limitations as the modeling approach. As noted above, the model boundary conditions do not explicitly represent some components of recharge and discharge in the study area and in the ZoneBudget zone used to account for the simulated effects of pumping at the Sprouse well. These boundaries include irrigation ditches that may be connected to the underlying aquifer and evapotranspiration from phreatophytes, which are limited mainly to areas along the river corridor. Future groundwater withdrawals could deplete flow to these boundaries. The influence of these boundaries within the ZoneBudget zone, however, is limited and likely small relative to the influence of source boundaries that are represented in the model. Although the effects of this limitation on simulated budgets for the ZoneBudget zone are likely small, simulated streamflow depletion within the zone (reported below) should be considered more representative of potential maximum rates. The specific origin of withdrawal-induced groundwater flow from outside the budget zone to the Sprouse well is assumed to be less certain and, therefore, is reported only as flow from outside the ZoneBudget zone boundary (table 8). Although depletion of flow at unrepresented boundaries may be more important outside the budget zone, it should be considered that some portion of flow to the well from outside the ZoneBudget zone is likely derived from streamflow depletion at the West Channel of the Uinta River outside the zone.

\section{Predictive Simulation-Annual Summer Pumping at Sprouse Well}

Changes in the values of water-budget components between the baseline simulation and the predictive model simulation incorporating annual summer pumping from the new Sprouse public-supply well over a 10 -year period are summarized in tables 8 and 9, and in figure 26a. In the first year of this predictive simulation, the model simulates 49 percent of the Sprouse well's 325 acre-ft of discharge as being derived from a net change in aquifer storage and 50 percent as being derived from depletion of streamflow in the West Channel of the Uinta River. By the 10th year, change in net flow to model boundaries from one stress period to the next does not change substantially. In the 10th year of simulation, 1 percent of the annual 325-acre-ft simulated withdrawal is derived from a net change in aquifer storage, 89 percent is derived from depletion of streamflow in the West Channel of the Uinta River, and 10 percent is derived from an increase in underflow from outside the ZoneBudget zone (table 8). No significant increase in flow from model layer 2, which represents the Duchesne River Formation, to model layer 1 from baseline conditions is predicted in this simulation.

The monthly change in the values of flow-budget components between the baseline simulation and the 9th and 10th years of this predictive simulation (stress periods 9 and 10) (fig. 26a) indicates that streamflow depletion (change in flow to or from the river in figure 26a) is predicted to continue after the simulated pumping ceases in the fall. For these periods, simulation results indicate that the river loses more and (or) gains less flow by about 8 acre-ft than in the baseline simulation in May of the following year, prior to the resumption of pumping in June. Although pumping begins in June each year, the month with the highest simulated rate of streamflow depletion relative to the baseline condition is September (fig. 26a).

In the 10th year of the predictive simulation, the maximum model-computed drawdown in the Sprouse well field is about $33 \mathrm{ft}$ (fig. 25). The drawdown cone has a diameter of influence of approximately $1 \mathrm{mi}$ and is oriented subparallel to the West Channel of the Uinta River, resulting in a steeper groundwater gradient toward the river than in other directions (north, west, and south).

This predictive simulation was used to assess the effects of increasing the vertical hydraulic conductivity of the Duchesne River Formation aquiclude, represented by model layer 2, on simulated storage changes and streamflow depletion resulting from pumping at the Sprouse well. An analysis of the sensitivity of the 2008-09 model calibration to varying vertical conductivity specified in model layer 2 over a reasonable range of values (Hood, 1976) indicated that values greater than $0.001 \mathrm{ft} / \mathrm{d}$ resulted in (1) substantial changes in simulated flow patterns, (2) large discrepancies between model-computed and observed water levels, and (3) substantial changes in flow at river boundaries. Specifying a vertical hydraulic conductivity of $0.001 \mathrm{ft} / \mathrm{d}$ for model 
Table 8. Summary of model-computed depletions of streamflow based on the simulation of potential annual summer groundwater withdrawal from the Sprouse well, Roosevelt Valley, Utah.

[Values in red are the results of sensitivity investigations for higher hydraulic-conductivity ranges for the underlying Duchesne River Formation]

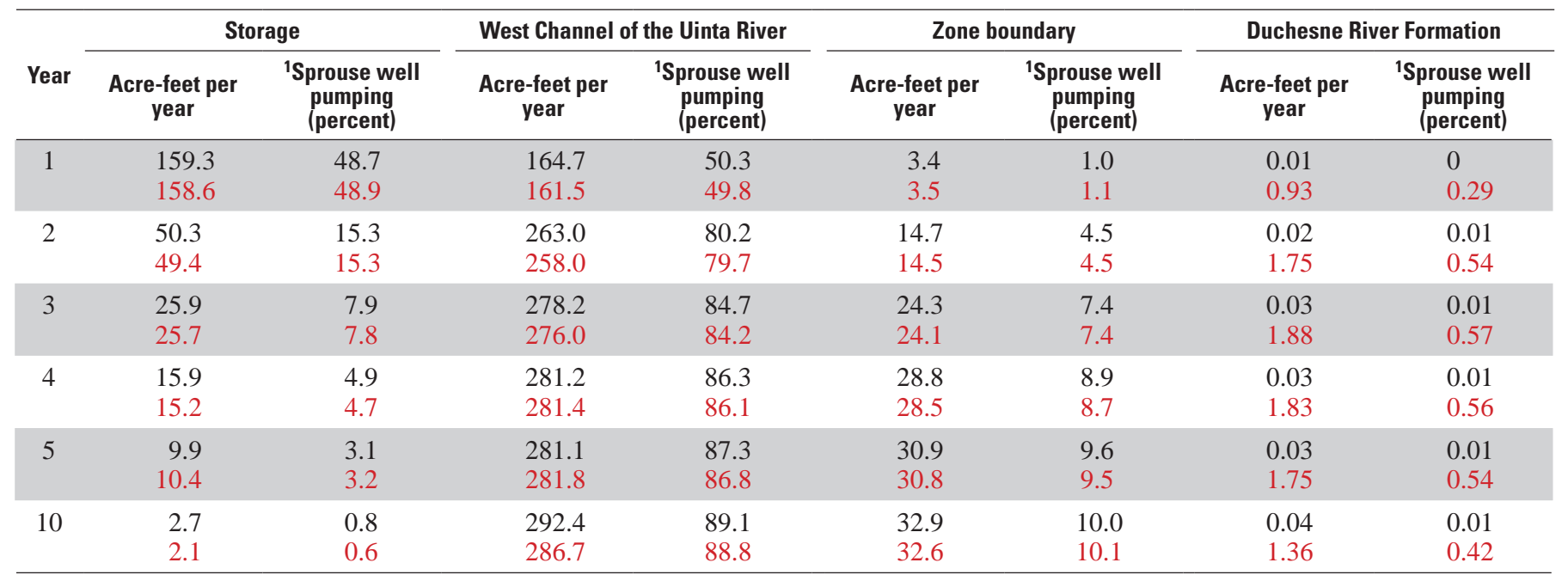

${ }^{1}$ Proposed annual pumping at the Sprouse well is approximately equal to 325 acre-feet per year.

Table 9. Summary of model-computed depletions of streamflow based on the simulation of biennial summer groundwater withdrawal from the Sprouse well, Roosevelt Valley, Utah.

\begin{tabular}{|c|c|c|c|c|c|c|c|c|}
\hline \multirow[b]{2}{*}{ Years } & \multicolumn{2}{|c|}{ Storage } & \multicolumn{2}{|c|}{ Uinta River } & \multicolumn{2}{|c|}{ Zone boundary } & \multicolumn{2}{|c|}{ Duchesne River Formation } \\
\hline & $\begin{array}{c}\text { Acre-feet per } \\
\text { year }\end{array}$ & $\begin{array}{l}\text { Percent of } \\
\text { proposed } \\
\text { pumping } \\
\text { volume }^{1}\end{array}$ & $\begin{array}{c}\text { Acre-feet per } \\
\text { year }\end{array}$ & $\begin{array}{l}\text { Percent of } \\
\text { proposed } \\
\text { pumping } \\
\text { volume }^{1}\end{array}$ & $\begin{array}{c}\text { Acre-feet per } \\
\text { year }\end{array}$ & $\begin{array}{l}\text { Percent of } \\
\text { proposed } \\
\text { pumping } \\
\text { volume }^{1}\end{array}$ & $\begin{array}{c}\text { Acre-feet per } \\
\text { year }\end{array}$ & $\begin{array}{c}\text { Percent of } \\
\text { proposed } \\
\text { pumping } \\
\text { volume }^{1}\end{array}$ \\
\hline $1-2$ & 69.2 & 21.1 & 250.5 & 76.5 & 7.78 & 2.38 & 0.02 & 0.01 \\
\hline $3-4$ & 19.6 & 5.98 & 279.6 & 85.6 & 27.5 & 8.43 & 0.03 & 0.01 \\
\hline $5-6$ & 10.1 & 3.07 & 287.4 & 87.2 & 32.1 & 9.73 & 0.03 & 0.01 \\
\hline $9-10$ & 3.36 & 1.02 & 292.7 & 88.7 & 34.0 & 10.3 & 0.04 & 0.01 \\
\hline
\end{tabular}

Proposed pumping at the Sprouse well is approximately equal to 325 acre-ft every other year.

layer 2 (which can be assumed to be the maximum probable value) had little effect on the total budget for the system or on estimated streamflow depletion caused by pumping at the Sprouse public-supply well (table 8).

\section{Predictive Simulation-Biennial Summer Pumping at Sprouse Well}

A second predictive simulation was developed to assess changes in simulated sources of water, including streamflow depletion, to the potential future Sprouse well if the well were pumped only every other year. Changes in the values of water-budget components between the baseline simulation and the biennial summer pumping simulation for a 10 -year period are summarized in table 9. During the year when the Sprouse well was not pumped, simulated water levels recovered locally as water, mainly river seepage and underflow from outside the ZoneBudget zone, moved into aquifer storage. Although simulated aquifer storage and water-table altitudes recover every other year while the Sprouse well is not being pumped, simulation results indicate a similar distribution of change in flow from recharge sources to that simulated for annual summer pumping (tables 8 and 9). Because much more water is available in storage in this scenario, the streamflow is depleted at a lower rate and over a greater time period than in the annual Sprouse well pumping scenario (fig. 26b). However, the percentage of the 325 acre-ft of simulated Sprouse well discharge that is derived from streamflow depletion during the 9th and 10th years of the simulation (a pumping year and the following year) is similar to that predicted in the annual summer pumping simulation (tables 8 and 9) each year. In the 9th and 10th years of the biennial summer pumping simulation, about 89 percent of Sprouse well discharge is derived from streamflow depletion. 

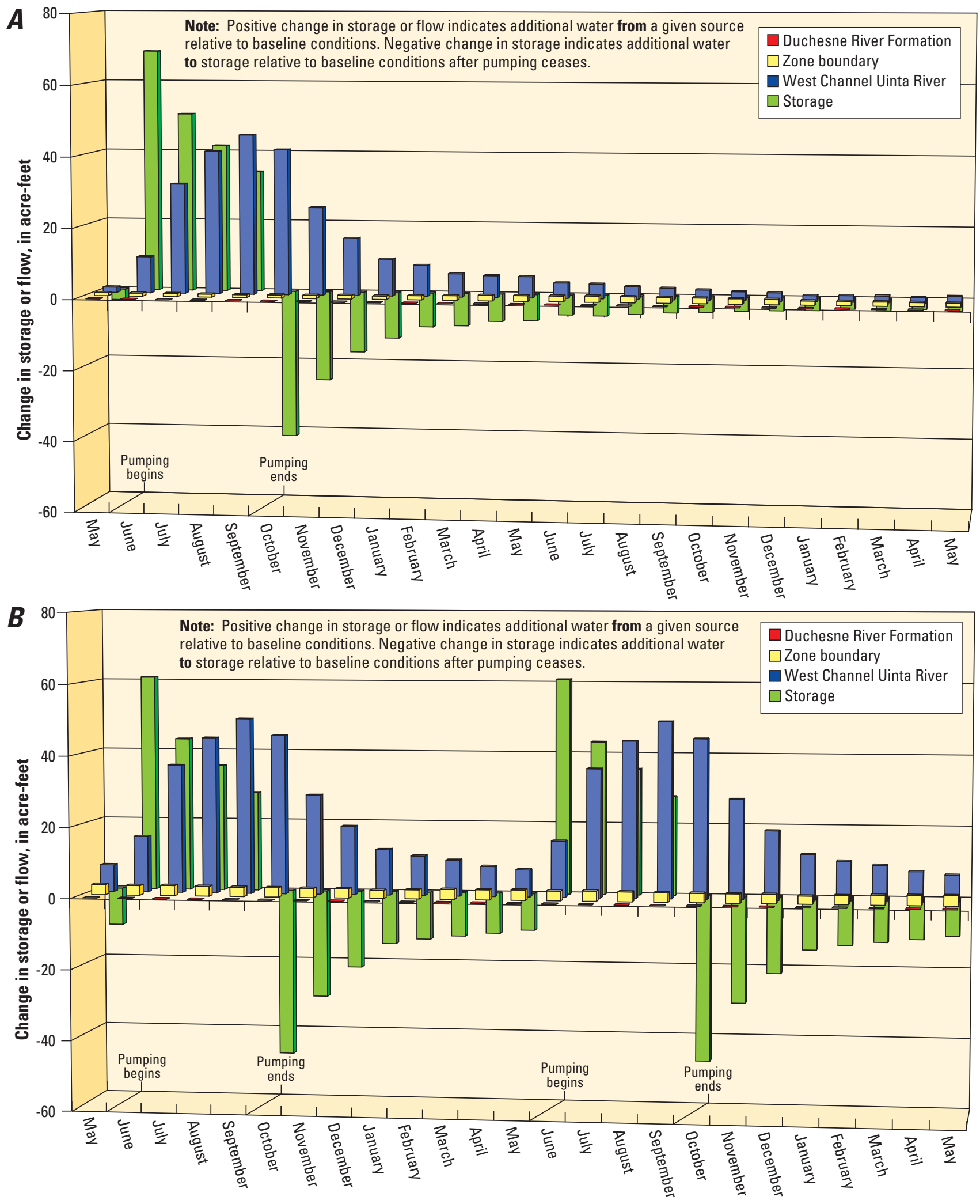

Figure 26. Model-computed changes for the 9th and 10th years of a 10-year simulation in 1, storage in the glacial outwash aquifer represented by model layer 1, 2, flow to or from the West Channel of the Uinta River, 3, flow from the Duchesne River Formation represented by model layer 2, and 4, flow at the Zonebudget boundary resulting from $A$, simulated biennial groundwater withdrawal from the Sprouse well, and $B$, simulated annual groundwater withdrawal from the Sprouse well, Roosevelt Valley, Utah. 


\section{Summary}

Groundwater is the source of drinking water for Roosevelt City in Roosevelt Valley, Utah. A need for additional groundwater supply for the city has been projected and potential locations for future groundwater development, including locations near the Uinta River, are being assessed by local water-resource managers. In 2008, the U.S. Geological Survey (USGS), in cooperation with Roosevelt City, the Utah Department of Natural Resources, and the Ute Indian Tribe, as part of groundwater management and planning assessments, began a study of potential streamflow depletion from future groundwater withdrawals at one possible Roosevelt City development location - the Sprouse well field near the West Channel of the Uinta River. A combination of indirect methods was used to measure groundwater movement near the stream and groundwater flow modeling was used to constrain estimates of the effects, including streamflow depletion, of this potential future groundwater withdrawal on the stream/aquifer system.

Groundwater in Roosevelt Valley and within the study area is found principally in an unconfined, Quaternary-age glacial outwash aquifer composed of unconsolidated rocks and sediment from varied sources in the Uinta Mountains. The glacial outwash aquifer is underlain by the Duchesne River Formation, composed mostly of shale with sandstone interbeds. Information from previous studies indicates that the consolidated-rock Duchesne River Formation is substantially less permeable than the overlying glacial outwash and likely acts as an aquiclude, limiting groundwater interaction with the overlying unconsolidated aquifer. An 11-day aquifer test was conducted to characterize the glacial outwash aquifer in the vicinity of the Sprouse well field. Estimates of transmissivity of the aquifer at the Sprouse well field ranged from about $1,600 \mathrm{ft}^{2} / \mathrm{d}$ east of the Durigan well to 2,300 $\mathrm{ft}^{2} / \mathrm{d}$ west of the Durigan well. Specific yield was estimated to be about 0.05 to 0.10 .

Groundwater in the glacial outwash aquifer moves southeast through the valley and the study area, generally parallel to the Uinta River. The Uinta River is a source of recharge to groundwater in reaches where stream water seeps through the streambed to the water table, and receives groundwater discharge in other reaches where groundwater moves through the streambed to the river. The Sprouse well field, approximately 6 mi northeast of Roosevelt City, is located within $1,500 \mathrm{ft}$ of the West Channel of the Uinta River. The well field includes one existing public-supply well (the Durigan well) and an unused well (the Sprouse well), originally developed as an irrigation well, that is being evaluated by Roosevelt City for possible conversion to a public-supply well.

Stream/aquifer interactions in the study area, and changes of those interactions over time, were assessed using three methods: (1) synoptic measurement of discharge in the stream at multiple sites using slug and continuous tracerdilution methods, (2) periodic measurement of vertical hydraulic gradient across the streambed, and (3) continuous measurement of streambed and stream temperature as a tracer of groundwater flow. Although some contradiction among the results obtained by using the three methods was observed, the results generally indicate (1) losing streamflow conditions north of and upstream from the Sprouse well field within the study area, and (2) gaining streamflow conditions south of and downstream from the well field. Vertical hydraulic gradient across the streambed (measured periodically during the study) and streambed temperature (monitored continuously during the study) indicate that these conditions may change with time as stream stage and local water-table altitudes in the study area vary seasonally.

A numerical groundwater flow model was developed on the basis of results of previous studies and data collected during this study to simulate the groundwater system in the vicinity of the Sprouse well field. The principal objective of the modeling approach was to assess stream/aquifer interaction and potential streamflow depletion in parts of the study area that might be affected by future groundwater withdrawals from the Sprouse well field.

Three transient-state models were constructed using the USGS MODFLOW-2005 model code: (1) a simulation of observed hydrologic conditions for the study period from August 1, 2008, to July 31, 2009 (the 2008-09 simulation); and (2) two predictive simulations of potential future conditions, including projected groundwater withdrawal from the Sprouse well for public supply. The models incorporate concepts of transient groundwater flow conditions, including fluctuations in groundwater levels and storage, and the distribution of and temporal variations in gains to and losses from streamflow in the Uinta River near the Sprouse well field. In general, results of the 2008-09 simulation indicate a good match between model-computed and observed water levels throughout the model domain. Observed local waterlevel fluctuations in response to 2008-09 withdrawals from the currently active Durigan public-supply well and from the Sprouse well during a November 2008 aquifer test also generally matched the 2008-09 model simulated waterlevel fluctuations. The results of this simulation indicate predominantly losing conditions in the West Channel of the Uinta River north of and upstream from the Sprouse well field and predominantly gaining conditions south of and downstream from the well field. These results generally agree with field observations made during the study.

Two predictive simulations were developed on the basis of model parameters established in the 2008-09 simulation to assess possible streamflow depletion resulting from the potential future groundwater withdrawal from the Sprouse well. The first predictive simulation incorporated pumping $1,200 \mathrm{gal} / \mathrm{min}$ at the new Sprouse public-supply well from June through September, 12 hours on and 12 hours off each day, for a total withdrawal of 325 acre-ft annually for a 10 -year period. The second simulation incorporated the same summer pumping rate at the new Sprouse well, but with pumping occurring every other year. Results of the Sprouse 
well predictive simulations were compared to those of a baseline simulation that did not include pumping the Sprouse well, and differences in the simulated monthly and annual budgets over the 10-year period were calculated. Differences between the baseline and predictive simulation results were calculated for a 2-mi by 2-mi ZoneBudget zone with the Sprouse well at the center. Identified sources of Sprouse well discharge included (1) aquifer storage, (2) streamflow depletion, (3) flow from the underlying Duchesne River Formation, and (4) flow from outside the budget zone.

Changes in the values of water-budget components between the baseline simulation and the predictive simulation incorporating annual summer pumping from the Sprouse public-supply well indicate that most of the simulated increase in withdrawal is supplied by depletion of flow from the West Channel of the Uinta River in the vicinity of the well field. In the first year of this predictive simulation, the model simulates 49 percent of the Sprouse well's 325 acre-ft of discharge as being supplied by a net change in aquifer storage and 50 percent by depletion of streamflow in the West Channel of the Uinta River. By the 10th year of the simulation, only 1 percent of the annual 325 acre-ft of withdrawal is simulated as coming from a net change in aquifer storage, whereas 89 percent is simulated as being derived from depletion of streamflow in the West Channel of the Uinta River and 10 percent is simulated as being derived from an increase in underflow into the budget zone. Simulation of Sprouse well pumping did not result in a substantial change in simulated flow from model layer 2 , representing the Duchesne River Formation, to model layer 1 , representing the glacial outwash aquifer, from baseline conditions.

Results of the predictive simulation incorporating biennial summer pumping from the Sprouse public-supply well indicate that although simulated aquifer storage and watertable altitudes recover every other year while the Sprouse well is not pumping, model-computed changes in flow from recharge sources are similar to those in the annual summer pumping predictive simulation. In the 9th and 10th years of the biennial summer pumping simulation, about 89 percent of simulated Sprouse well discharge is derived from streamflow depletion, about 10 percent is from flow from sources outside the budget zone, and about 1 percent is from a net change in aquifer storage. No substantial change in flow from model layer 2, representing the Duchesne River Formation, to model layer 1, representing the glacial outwash aquifer, from baseline conditions was simulated.

\section{References Cited}

Anderson, D.W., and Picard, M.D., 1972, Stratigraphy of the Duchesne River Formation (Eocene-Oligocene?), northern Uinta Basin, northeastern Utah: Utah Geological and Mineralogical Survey Bulletin, No. 97, 29 p.
Bencala, K.E., McKnight, D.M., and Zellweger, G.W., 1990, Characterization of transport in an acidic and metal-rich mountain stream based on a lithium tracer injection and simulations of transient storage: Water Resources Research, v. 26, p. 989-1000.

Constantz, J., and Stonestrom, D.A., 2003, Heat as a tracer of water movement near streams, in Constantz, J., and Stonestrom, D.A., eds., Heat as a tool for studying movement of groundwater near streams: U.S. Geological Survey Circular 1260, p. 1-6.

Duchesne County Water Conservancy District, 2009, Duchesne River and tributaries of Utah: Real-time water \& weather data: accessed June 22, 2009, at http://www. duchesneriver.org/rivers/uinta-white-rocks/.

Duffield, G.M., 2006, AQTESOLV for Windows version 4.04 user's guide: HydroSOLVE, Inc., Reston, VA.

Fitts, C.R., 2002, Groundwater science: San Diego, CA, Academic Press, $450 \mathrm{p}$.

Harbaugh, A.W., 1990, A computer program for calculating subregional water budgets using results from the U.S. Geological Survey modular three-dimensional ground-water flow model: U.S. Geological Survey Open-File Report 90-392, 46 p.

Harbaugh, A.W., 2005, MODFLOW-2005, The U.S. Geological Survey modular ground-water model-The ground-water flow process: U.S. Geological Survey Techniques and Methods, book 6, section A, chap. 16, variously paged.

Harvey, J.W., and Bencala, K.E., 1993, The effect of streambed topography on surface-subsurface water exchange in catchments: Water Resources Research, v. 29, p. 89-98.

Harvey, J.W., Wagner, J.J., and Bencala, K.E., 1996, Evaluating the reliability of the stream tracer approach to characterize stream-subsurface water exchange: Water Resources Research, v. 32, p. 2441-2451.

Hood, J.W., 1976, Characteristics of aquifers in the northern Uinta Basin area, Utah and Colorado: Utah Department of Natural Resources, Technical Publication No. 53, 71 p.

Hood, J.W. , and Fields, F.K., 1978, Water resources of the northern Uinta Basin area, Utah and Colorado, with special emphasis on groundwater supply: Utah Department of Natural Resources, Technical Publication No. 62, 75 p.

Hood, J.W., Mundorff, J.C., and Price, Don, 1976, Selected hydrologic data, Uinta Basin area, Utah and Colorado: U.S. Geological Survey Utah Basic-Data Release No. 26, 321 p. 
Horrocks Engineering, 2003, Drinking water source protection plan, Roosevelt City Sprouse Well Field Well \#1: American Fork, Utah, Horrocks Engineering variously paged.

Horrocks Engineering, 2004, Drinking water source protection plan, Hayden Well Field: American Fork, Utah, Horrocks Engineering, variously paged.

Jacob, C.E., 1963, Determining the permeability of watertable aquifers, in Bentall, R., ed., Methods for determining permeability, transmissibility and drawdown: U.S. Geological Survey Water-Supply Paper 1536-I, p. 245-271.

Jarrett, R.D., 1992, Hydraulics of mountain rivers, in Yen, B.C., ed., Channel flow resistance, centennial of Manning's formula: International Conference of the Centennial of Manning's and Kuichling's Rational Formula: Littleton, Colorado, Water Resources Publications, p. 287-298.

Kilpatrick, F.A., and Cobb, E.D., 1985, Measurement of discharge using tracers: U.S. Geological Survey Techniques of Water-Resources Investigations, book 3, chap. A16, 27 p.

Kimball, B.A., 1997, Use of tracer injections and synoptic sampling to measure metal loading from acid mine drainage: U.S. Geological Survey Fact Sheet FS-245-296, $4 \mathrm{p}$.

Leake, S.A., and Prudic, D.E., 1991, Documentation of a computer program to simulate aquifer system compaction using modular finite-difference ground-water flow model: U.S. Geological Survey Techniques of Water-Resources Investigations, book 6, chap. A2, 68 p.

Leake, S.A., and Reeves, H.W., 2008, Use of models to map potential capture of surface water by ground-water withdrawals - Proceedings of the MODFLOW and More: Ground Water and Public Policy Conference, May 18-21, 2008, Colorado School of Mines, Golden, CO, International Ground Water Modeling Center, p. 204-208.

Natural Resources Conservation Service, 2010, Utah snow survey data: accessed April 5, 2010, at http://www.ut.nrcs. usda.gov/snow/data/historic.html.

Neuman, S.P., 1972, Analysis of flow in unconfined aquifers considering delayed response of the water table: Water Resources Research, v. 8, p. 1031-1045.
Neuman, S.P., 1975, Analysis of pumping test data from anisotropic unconfined aquifers considering delayed gravity response: Water Resources Research, v. 11, p. 329-342.

Rantz, S.E., and others, 1982, Measurement and computation of streamflow: Volume 1. Measurement of stage and discharge: U.S. Geological Survey Water-Supply Paper 2175, 284 p.

Stonestrom, D. A., and Blasch, K.W., 2003, Determining temperature and thermal properties for heat-based studies of surface-water/ground-water interactions, in Constantz, J., and Stonestrom, D.A., eds., Heat as a tool for studying movement of groundwater near streams: U.S. Geological Survey Circular 1260, p. 73-78.

Theis, C.V., 1935, The relation between the lowering of the piezometric surface and the rate and duration of discharge of a well using ground-water storage: American Geophysical Union Transactions, v. 16, p. 519-524.

Theis, C.V., 1940, The source of water derived from wells: Essential factors controlling the response of an aquifer to development: Civil Engineering v. 10, no. 5, p. 277-280.

U.S. Geological Survey, 1991, U.S. Geological Survey topographic quadrangle map, Whiterocks, Utah: Reston, VA, scale 1:24,000.

U.S. Geological Survey National Gap Analysis Program, 2004, Provisional digital land cover map for the southwestern United States, Version 1.0. RS/GIS Laboratory, College of Natural Resources, Utah State University, Logan, Utah: accessed April 5, 2010 at http://earth.gis.usu.edu/swgap/ landcover.html.

Winter, T.C., Harvey, J.W., Franke, O.L., and Alley, W.M., 1998, Ground water and surface water: A single resource: U.S. Geological Survey Circular 1139, 79 p.

Zellweger, G.W., Avanzino, R.J., and Bencala, K.E., 1989, Comparison of tracer-dilution and current-meter discharge measurements in a small gravel-bed stream, Little Lost Man Creek, California: U.S. Geological Survey Water-Resources Investigations Report 89-4150, 20 p. 

혹

옥

흘 을

총 옹

들

刃

꿍

ฐ

ㅎํ ำ

윽웅

구음

웅 도

呙

칭

돟

象

ㅎำ

票

폭

寻

需

옴.

을 흘

ग्र

등

욱 올

도ㅇㅡㅡ

등

응

7

유

흘

急

흥

$\Sigma$

울 